\title{
Integrated Pyrolysis Combined Cycle Biomass Power System Concept Definition Final Report
}

Reporting Period Start Date: 9/28/01

Reporting Period End Date: 9/28/02

\section{Report Date: March 2003 \\ DE-FS26-01NT41353}

Submitted by:

Alliant Energy

200 First Street SE

P.O. Box 351

Cedar Rapids, lowa 52406-0351

Center for Sustainable Environmental Technologies lowa State University

285 Metals Development Bldg. Ames, lowa 50011-3020

DynaMotive Energy Systems Corp Angus Corporate Centre 105-1700 West $75^{\text {th }}$ Ave

Vancouver BC Canada V6P 6G2

Black \& Veatch Corporation 11401 Lamar Avenue Overland Park, Kansas 66211 


\section{Disclaimer}

This report was prepared as an account of work sponsored by an agency of the United States Government. Neither the United States Government nor any agency thereof, nor any of their employees, makes any warranty, express or implied, or assumes any legal liability or responsibility for the accuracy, completeness, or usefulness of any information, apparatus, product, or process disclosed, or represents that its use would not infringe privately owned rights. Reference herein to any specific commercial product, process, or service by trade name, trademark, manufacturer, or otherwise does not necessarily constitute or imply its endorsement, recommendation, or favoring by the United States Government or any agency thereof. The views and opinions of authors expressed herein do not necessarily state or reflect those of the United States Government or any agency thereof. 


\section{Abstract}

Advanced power systems based on integrated gasification/combined cycles (IGCC) are often presented as a solution to the present shortcomings of biomass as fuel. Although IGCC has been technically demonstrated at full scale, it has not been adopted for commercial power generation. Part of the reason for this situation is the continuing low price for coal. However, another significant barrier to IGCC is the high level of integration of this technology: the gas output from the gasifier must be perfectly matched to the energy demand of the gas turbine cycle.

We are developing an alternative to IGCC for biomass power: the integrated (fast) pyrolysis/ combined cycle (IPCC). In this system solid biomass is converted into liquid rather than gaseous fuel. This liquid fuel, called bio-oil, is a mixture of oxygenated organic compounds and water that serves as fuel for a gas turbine topping cycle. Waste heat from the gas turbine provides thermal energy to the steam turbine bottoming cycle.

Advantages of the biomass-fueled IPCC system include: combined cycle efficiency exceeding 37 percent efficiency for a system as small as 7.6 $\mathrm{MW}_{\mathrm{e}}$; absence of high pressure thermal reactors; decoupling of fuel processing and power generation; and opportunities for recovering value-added products from the bio-oil.

This report provides a technical overview of the system including pyrolyzer design, fuel clean-up strategies, pyrolysate condenser design, opportunities for recovering pyrolysis byproducts, gas turbine cycle design, and Rankine steam cycle. The report also reviews the potential biomass fuel supply in Iowa, provide and economic analysis, and present a summery of benefits from the proposed system. 


\section{Table of Contents}

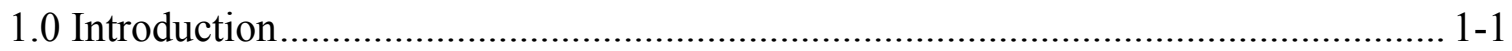

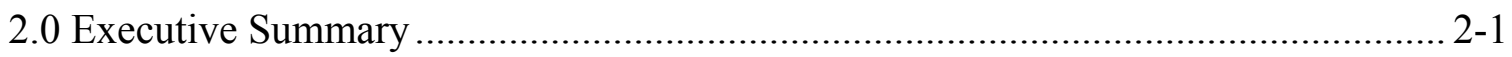

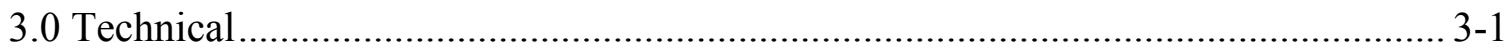

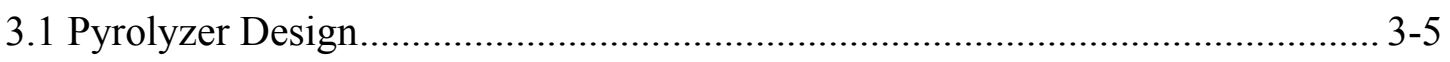

3.1.1 Pyrolysis Introduction .................................................................. 3-5

3.1.2 Fast Pyrolysis of Biomass .............................................................. 3-6

3.1.3 Fast Pyrolysis Heat and Mass Balance .................................................. 3-8

3.1.4 Bio-Oil Analysis ................................................................................. 3-9

3.1.5 Market Competitiveness ....................................................................... 3-11

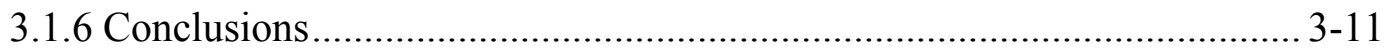

3.2 Fuel Clean-up Strategies .......................................................................... 3-12

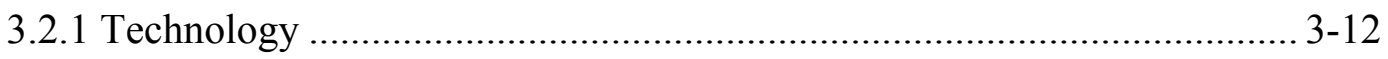

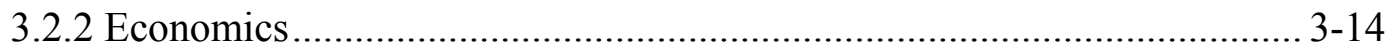

3.3 Pyrolysate Condenser Design ............................................................. 3-16

3.3.1 Staged Condenser..................................................................... 3-16

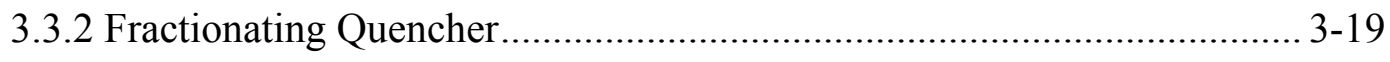

3.4 Opportunities for Recovering Pyrolysis Byproducts .................................... 3-25

3.4.1 Recovery of Activated Carbon from Pyrolysis Char ............................. 3-25

3.4.2 Recovery of Organic Compounds from Bio-oil................................... 3-30

3.4.3 Utilization of Levoglucosan............................................................ 3-34

3.4.4 Economics of Levoglucosan Recovery from Bio-oil Production ............. 3-37

3.4.5 Comparative Economics of Levoglucosan for Ethanol Production.......... 3-39

3.5 Gas Turbine Cycle Design ...................................................................... 3-41

3.5.1 Introduction to Gas Turbine Technology ............................................. 3-41

3.5.2 Bio-Oil Properties Relevant to Gas Turbine Engines ............................. 3-43

3.5.3 Combustion Turbine Options............................................................... 3-43

3.5.4 OGT2500 Combustion Turbine ........................................................ 3-45

3.5.5 Combustion Turbine Testing ............................................................. 3-48

3.6 Rankine Steam Cycle Design................................................................... 3-48

3.6.1 Rankine Steam Cycle Overview ..................................................... 3-48

3.6.2 Design Approach ........................................................................... 3-49

3.6.3 Combined Cycle Heat and Mass Balance ............................................ 3-49

3.6.4 Overall Process Efficiency Calculations............................................. 3-52 


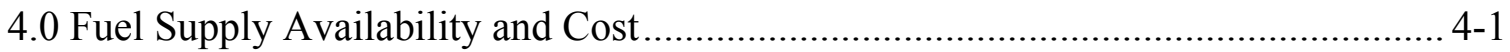

4.1 Corn Stover ......................................................................................... 4-1

4.1.1 Corn Stover Fuel Properties........................................................... 4-2

4.1.2 Corn Stover Fuel Availability and Requirements ...................................... 4-4

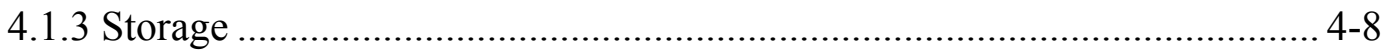

4.1.4 Harvesting Equipment …………......................................................... 4-9

4.1.5 Corn Stover Delivered Cost .................................................................. 4-9

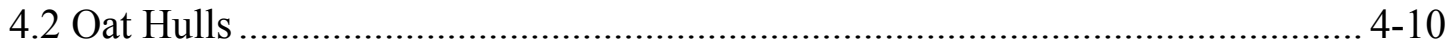

4.2.1 Oat Hull Fuel Properties ................................................................... 4-10

4.2.2 Oat Hulls Fuel Availability .................................................................. 4-12

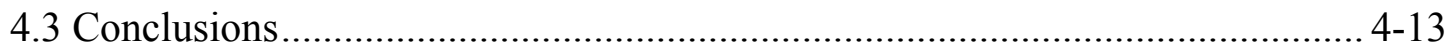

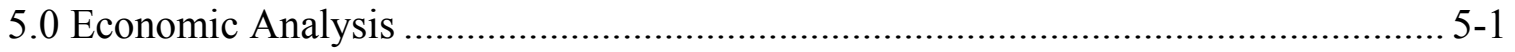

5.1 Pro Forma Overview ............................................................................... 5-1

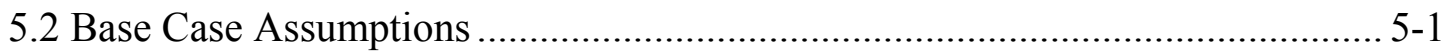

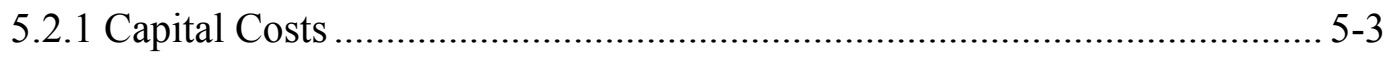

5.2.2 Operating and Maintenance Costs ..................................................... 5-4

5.3 Renewable Energy Credits.......................................................................... 5-5

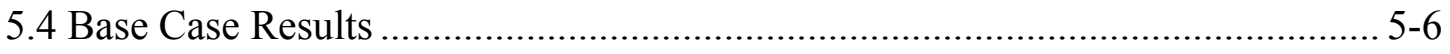

5.4.1 Maximum Power Production Option ...................................................... 5-6

5.4.2 Value-Added Chemical Option.............................................................. 5-7

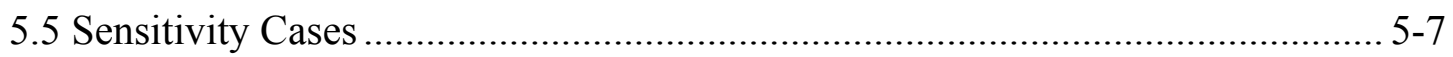

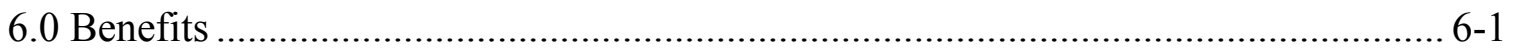

6.1 Power, Heat, and Byproducts......................................................................... 6-1

6.2 Rural Development Benefits......................................................................... 6-1

6.3 Environmental Quality and Greenhouse Gas Emissions ...................................... 6-2

6.4 Project Sustainability and Opportunities for Replication .................................... 6-2

6.5 Economic Benefits .......................................................................................... 6-3

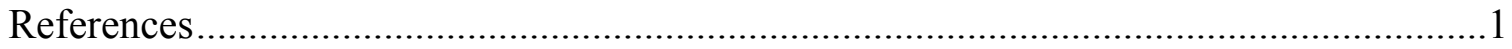

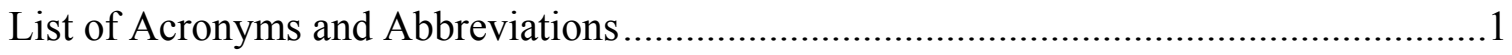

Appendix A. Fractionating Condenser Cost Estimation Approach .....................................1

Appendix B. Example Pro Forma Model ………….................................................... 


\section{Lists of Graphical Materials}

Tables

Table 3-1. Process Design Criteria. 3-5

Table 3-2. DynaMotive Bio-Oil Properties. ............................................................... 3-10

Table 3-3. Bio-Oil Composition (Wt\%) ............................................................. 3-10

Table 3-4. Summary of Methodology for Capital Cost Calculations. .......................... 3-17

Table 3-5. Pyrolysis Products for Woody Biomass (Bone-Dry Western Hemlock;

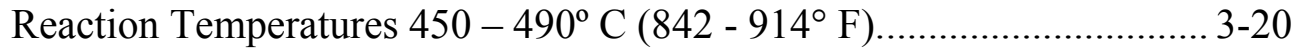

Table 3-6. Pyrolysis Products for Herbaceous Biomass (Bone-Dry Corn Stover; Reaction

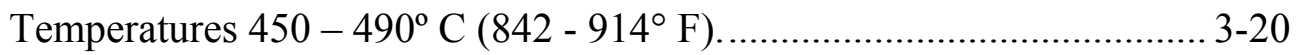

Table 3-7. Concentrations of Several Elements (as Oxide Forms) in Oat Hull Char and Corn Stover Char.

Table 3-8. Activation Burn-Off, Loss Due to Washing, BET Surface Area and Pore Size

Distribution of Oat Hull Activated Carbons. 3-30

Table 3-9. Activation Burn-Off, Loss Due to Washing, BET Surface Area and Pore Size Distribution of Corn Stover Activated Carbons. 3-30

Table 3-10. Yields of Organic Compounds in Pyrolysis Syrups for Pretreatments of Corn

Stover. 3-31

Table 3-11. Boiling Points of Some Monomeric Lignin-Related Phenols. 3-32

Table 3-12. Boiling Points of Some Low Molecular Weight Carbonyls. 3-34

Table 3-13. Cost Estimate for Biomass Pretreatment System. 3-38

Table 3-14. Summary of Capital Costs and Operating Costs for Recovering Levoglucosan from Pyrolyzed Biomass.

Table 3-15. Costs of Dry Milling Corn in Minnesota...... $3-40$

Table 3-16. Typical Properties of Bio-Oil Compared to Diesel Fuel........................... 3-43

Table 3-17. Small Gas Turbine Characteristics...................................................... 3-44

Table 3-18. OGT2500 Predicted Performance on Bio-oil....................................... 3-45

Table 3-19. Combined Cycle Heat and Mass Balance. ............................................. 3-50

Table 3-20. Net Combined Cycle Efficiency Calculations (LHV basis)..................... 3-53

Table 3-21. Annual Average Total Fuel Cycle Efficiency Calculations (LHV). ......... 3-54

Table 4-1. Corn Stover Analysis............................................................................ 4-4

Table 4-2. Corn Stover ${ }^{\mathrm{a}}$ Requirements for Pyrolysis Plant Operations........................ 4-8

Table 4-3 Ground Oat Hull Ultimate Analysis ...................................................... 4-11

Table 5-1. Economic Analysis Assumptions (2003 \$US) ......................................... 5-2

Table 5-2. Capital Cost Estimate (2003 US\$). ........................................................ 5-3 
Table 5-3. Operating and Maintenance Cost Estimate (2003 US\$)............................ 5-5

Table 5-4. Summary Economic Analysis Results................................................. 5-6 
Figures

Figure 3-1. IPCC Power Plant Conceptual Design..................................................... 3-2

Figure 3-2. IPCC Power Plant General Arrangement..................................................... 3-3

Figure 3-3. BioTherm ${ }^{\mathrm{TM}} 15$ TPD Pilot Plant, Vancouver, BC. .................................... 3-7

Figure 3-4. BioTherm ${ }^{\mathrm{TM}}$ Flow Sheet. ................................................................... 3-8

Figure 3-5. Comparison of Electrical Generating Options for a Tanzanian Sugar Mill (ref. Gabra and Kjellstrom)............................................................. 3-12

Figure 3-6. Moving Bed Granular Filter for Removing Particulate Matter from Pyrolysis

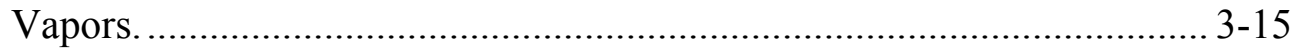

Figure 3-7. Pyrolysis Condensers: Water Cooled Shell-in-Tube Design. .................... 3-18

Figure 3-8. Concept for Fractionating Quencher.................................................... 3-22

Figure 3-9. Schematic of Fast Pyrolysis Pilot Plant Used in the Production of Pyrolytic Chars from Oat Hulls and Corn Stover............................................... 3-26

Figure 3-10. Addition Reaction of Levoglucosan with an Alkanol to give an Alkyl

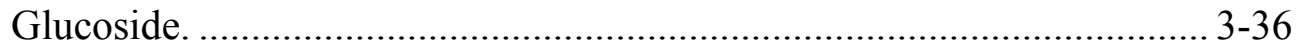

Figure 3-11. Biomass Washing and Drying System for Demineralizing Biomass....... 3-38

Figure 3-12. Gas Turbine Section (Source: Langston)......................................... 3-42

Figure 3-13. Application of Pyrolysis Oil to Gas Turbine Operation (OGT2500)....... 3-45

Figure 3-14. Pyrolysis Oil $\mathrm{NO}_{\mathrm{x}}$ Emission Reduction. ................................................. 3-48

Figure 4-1. Corn Stover Remnants. ...................................................................... 4-2

Figure 4-2. Square Baled Corn Stover............................................................. 4-2

Figure 4-3. Annual Corn Stover Potential (tonnes). .................................................... 4-6

Figure 4-4. Annual Corn Stover Potential (tonnes $/ \mathrm{km}^{2}$ )............................................ 4-7

Figure 4-5. Recommended Round Bale Storage (Side View).................................... 4-9

Figure 4-6. Oat Plant....................................................................................... 4-11

Figure 4-7. Oat Seeds with Hull. ........................................................................ 4-11

Figure 4-8. Oat Seeds with Hull Removed........................................................... 4-11

Figure 5-1. O\&M and Capital Cost Sensitivity Investigations.................................. 5-8

Figure 5-2. Biomass Cost Sensitivity Investigations. ............................................. 5-8

Figure 5-3. Anhydrosugar Sensitivity Investigation................................................ 5-9 


\subsection{Introduction}

Biomass would appear to be a logical fuel blend in existing coal-fired power plants. Both coal and biomass are solid fuels requiring more difficult storage, handling, and firing provisions compared to liquid or gaseous fuels. However, biomass has distinct physical and chemical characteristics that complicate the simple substitution of biomass for coal in existing boilers.

Advanced power systems based on integrated gasification combined cycles (IGCC) are often presented as a solution to the present shortcomings of biomass as fuel. Although IGCC has been technically demonstrated at full scale, it has not been widely adopted for power generation. Part of the reason for this situation is the continuing low price for coal. However, another significant barrier to IGCC is the high level of integration of this technology: the gas output from the gasifier must be perfectly matched to the energy demand of the gas turbine cycle.

This project evaluated an alternative to IGCC for biomass power: integrated (fast) pyrolysis combined cycle (IPCC). In this system, solid biomass is converted into liquid rather than gaseous fuel. This liquid fuel, called pyrolytic oil, is a mixture of oxygenated hydrocarbons and water that serves as fuel for a gas turbine topping cycle. Waste heat from the gas turbine provides thermal energy to a steam turbine bottoming cycle.

Advantages of the biomass-fueled IPCC system include: cycle efficiency exceeding that of biomass-fired Rankine cycles; does not require high pressure thermal reactors; reduces the strong coupling between fuel processing and power generation typical of integrated power systems; provides opportunities for recovering value-added products.

The overall objective of this project was to evaluate the feasibility of a biomass power system based on IPCC. Specific objectives included:

- Design a pyrolyzer to convert solid biomass to liquid fuel.

- Evaluate strategies for pretreatment of biomass feedstock and post-treatment of pyrolysate vapors to yield fuel clean enough for gas turbine applications.

- Design a combined gas turbine cycle and Rankine bottoming cycle that utilizes pyrolysate as fuel.

- Evaluate the characteristics of two pyrolysate recovery strategies.

- Optimize a Rankine bottoming cycle.

- Evaluate opportunities for separating high-value byproducts from pyrolytic products.

- Evaluate fuel supply availability and cost.

- Determine economic costs of the proposed biomass power system. 


\subsection{Executive Summary}

The IPCC concept combines a biomass pyrolysis plant with a conventional combined cycle power plant. In this system, solid biomass is converted into a liquid "bio-oil" that is a mixture of oxygenated hydrocarbons and water. This liquid serves as fuel for a gas turbine topping cycle. Waste heat from the gas turbine provides thermal energy to a steam turbine bottoming cycle.

Numerous configurations were examined in the conceptual design process. The designs included various levels of integration, heat recovery and efficiency, value-added chemical production, and other configurations. The overall design minimizes the integration among the pyrolysis and combined cycle plants, allowing the two to operate independently if necessary. In some cases, less efficient equipment was selected when significant cost savings could be realized.

Two basic configurations are presented in this report: Maximum Power Production Design in which the entire bio-oil output of the pyrolysis plant is used to fuel the combined power plant and Value-Added Chemicals Design where significant operational modifications and added costs allow recovery of value-added chemicals from the bio-oil resulting in lower flow of bio-oil to the power cycle. Oat hulls and corn stover were examined as potential fuels.

The proposed cycle could be commercially offered in the near term with minimal research and development needs. In contrast, implementation of the value-added products design will require the development of new technologies and will entail some technical risk.

The proposed IPCC system is estimated to have a total project cost of $\$ 18.4$ million, which, based on a net combined cycle output of $7,655 \mathrm{~kW}$, is equal to $\$ 2,400 / \mathrm{kW}$. For a small amount of additional capital, recovery of valuable chemicals may also be performed. The IPCC capital cost compares favorably to conventional biomass power systems in this size range, which cost between $\$ 2,000$ and $\$ 3,000 / \mathrm{kW}$.

The economic analysis evaluated a number of sensitivity cases to assess the impacts of key variables on the project economic viability. Key variables that were considered in the sensitivity analysis include: Capital cost, Operating and maintenance cost, Fuel cost and Anhydrosugar value. The analysis has shown that the maximum power option would not be competitive with traditional utility assets; however, this configuration appears to be competitive with other biomass options. Value-added chemical production greatly improves the economics of the project. To obtain the minimum equity return $(12 \%)$, a renewable energy credit of only $\$ 18 / \mathrm{MWh}$ (equal to the current production tax credit) would be needed for oat hulls. 


\subsection{Technical}

This section provides an overview of the technical design of the integrated pyrolysis combined cycle (IPCC) power plant.

In simple terms, the IPCC concept combines a biomass pyrolysis plant with a conventional combined cycle power plant. In this system, solid biomass is converted into a liquid "bio-oil" that is a mixture of oxygenated hydrocarbons and water. This liquid serves as fuel for a gas turbine topping cycle. Waste heat from the gas turbine provides thermal energy to a steam turbine bottoming cycle.

Numerous configurations were examined in the conceptual design process. The designs included various levels of integration, heat recovery and efficiency, value-added chemical production, and other configurations. Two basic configurations are presented in this report:

- Maximum Power Production Design - In this design the entire bio-oil output of the pyrolysis plant is used to fuel the combined power plant. A simple condenser is used to separate the oil from the non-condensable gases, and biomass pretreatment is minimal.

- Value-Added Chemicals Design - In this design, value-added chemicals are extracted from the bio-oil resulting in lower flow of bio-oil to the power cycle. Recovery of the chemicals requires additional biomass pre-treatment equipment, a fractionating condenser, and significant operational modifications and added costs.

The chosen design was developed by consensus among project team members as the best approach balancing technical risk, complexity, efficiency, and cost. In general, the overall design minimizes the integration among the pyrolysis and combined cycle plants, allowing the two to operate independently if necessary. In some cases, less efficient equipment was selected when significant cost savings could be realized. This was particularly true in the steam cycle design, as high efficiency equipment in this small size range demands a substantial cost premium. The maximum power production design includes largely standard equipment that involves minimal technical risk. Because of this approach, it is believed that the proposed cycle could be commercially offered in the near term with minimal research and development needs. In contrast, implementation of the value-added products design will require the development of new technologies and will entail some technical risk.

The conceptual cycle process flow is shown in Figure 3-1, and a general arrangement drawing is shown in Figure 3-2. 


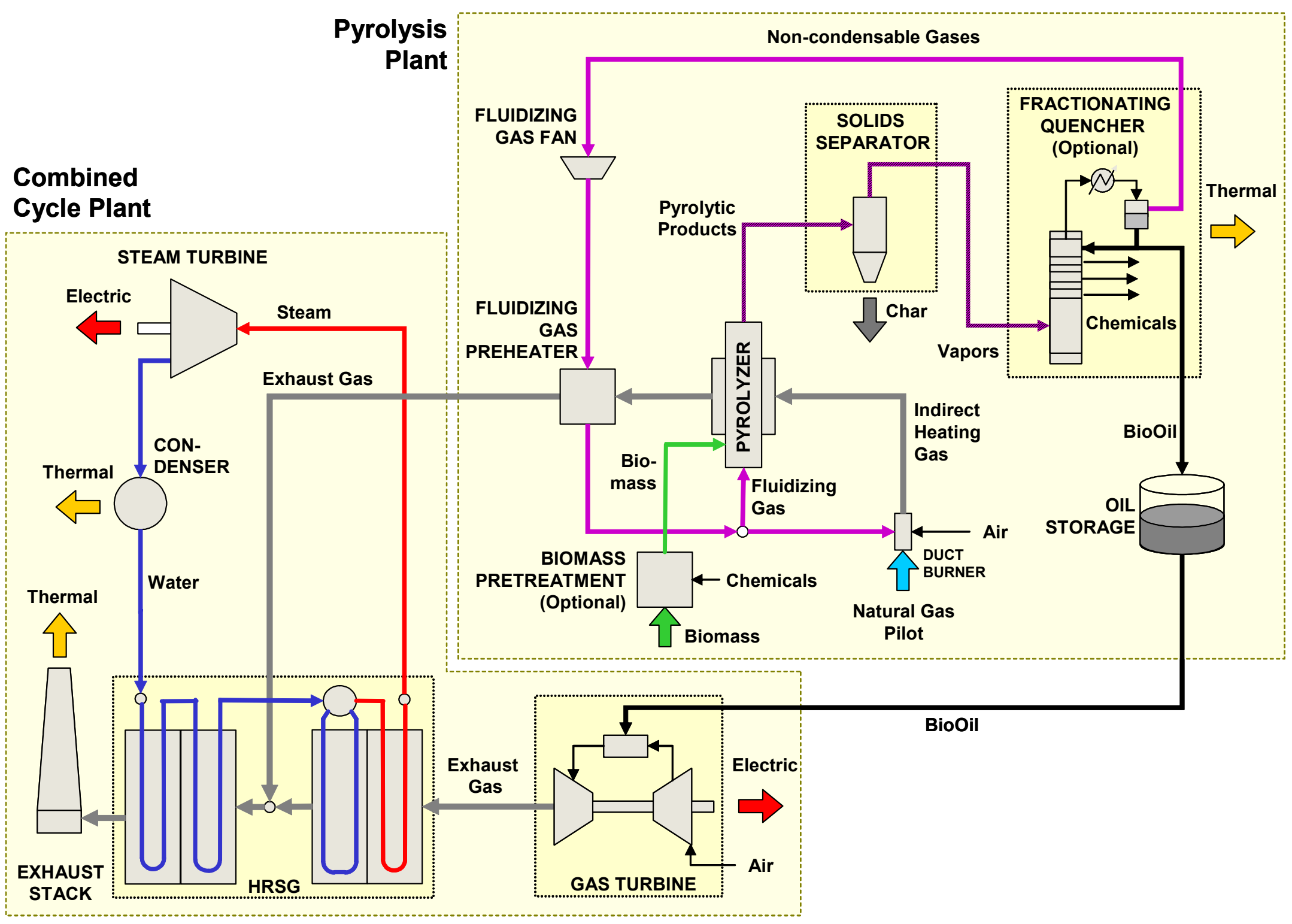

Figure 3-1. IPCC Power Plant Conceptual Design. 


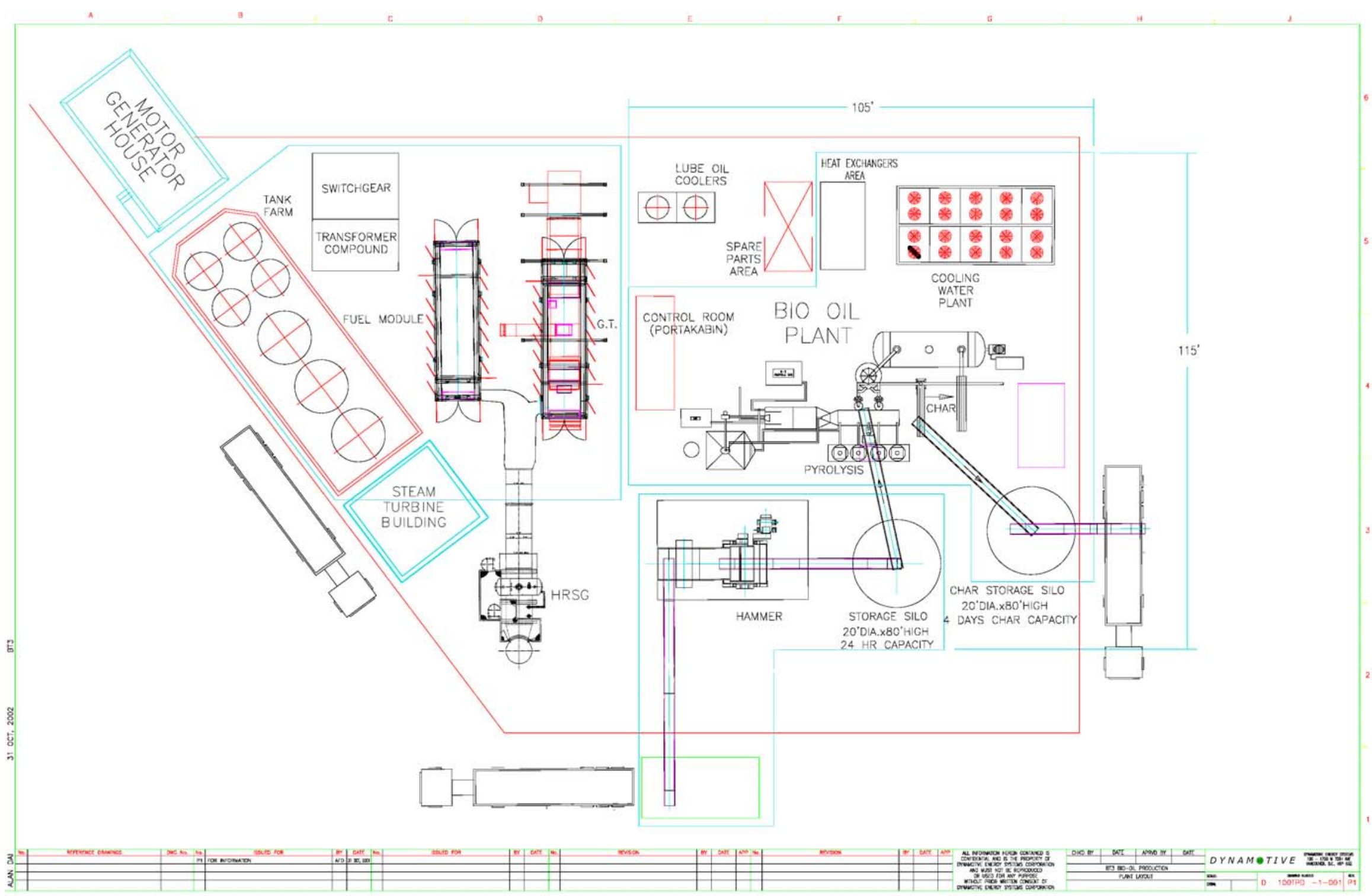

Figure 3-2. IPCC Power Plant General Arrangement. 
As mentioned previously, the cycle design consists of a pyrolysis plant and a combined cycle plant. The major components of each of these plants include the following:

- Pyrolysis Plant

- Biomass storage and handling system

- Biomass pretreatment (optional for recovery of value-added products)

- Biomass pyrolyzer

- Solids separator for recovery of char

- Condenser to separate bio-oil and non-condensable gases (optional replacement with a fractionating condenser for recovery of value-added products)

- Bio-oil storage

- Fluidizing gas and indirect heating gas systems

- Combined Cycle Plant

- Combustion turbine generator

- Heat recovery steam generator

- Steam turbine generator

- Cycle heat rejection equipment

Table 3-1 highlights the major design criteria for the project. Note that for the purposes of this level of evaluation, the properties of the two biomass fuel types were assumed to be similar. The only major relevant difference between the two at this stage is the fuel price. Combined with several other logistical issues described in Section 4 (Fuel Supply Availability and Cost), the lower fuel price of oat hulls makes it a promising candidate for the first application of the technology.

The remainder of this section describes critical technical design features of the various plant systems in detail. These sections include:

- Pyrolyzer design

- Fuel clean-up strategies

- Pyrolysate condenser design

- Opportunities for recovering pyrolysis byproducts (optional value-added products)

- Gas turbine cycle design

- Rankine steam cycle design 
Table 3-1. Process Design Criteria.

\begin{tabular}{|l|c|c|}
\hline \hline Biomass Information & Metric Units & English Units \\
Biomass fuel type & Oat hulls/ & Oat hulls/ \\
& corn stover & corn stover \\
Biomass moisture content (as fired) & 6.1 percent & 6.1 percent \\
Biomass higher heating value (LHV, as fired) & $15,665 \mathrm{~kJ} / \mathrm{kg}$ & $6,732 \mathrm{Btu} / \mathrm{lb}$ \\
Pyrolysis Plant & & \\
Biomass fuel feed rate (wet) & 5.39 tonne/hr & $5.94 \mathrm{ton} / \mathrm{hr}$ \\
Pyrolysis plant capacity factor & $90.4 \mathrm{percent}$ & $90.4 \mathrm{percent}$ \\
Annual biomass consumption & 42,700 tonne/yr & $47,100 \mathrm{ton} / \mathrm{yr}$ \\
Annual biomass consumption (energy, LHV) & $669,000 \mathrm{GJ} / \mathrm{yr}$ & $633,800 \mathrm{MBtu} / \mathrm{yr}$ \\
Pyrolysis yield (bio-oil / char) & $68 \% / 20 \%$ & $68 \% / 20 \%$ \\
Total annual bio-oil production & 29,000 tonne/yr & $32,000 \mathrm{ton} / \mathrm{yr}$ \\
Combined Cycle Plant & & \\
Total annual bio-oil consumption & 29,000 tonne/yr & $32,000 \mathrm{ton} / \mathrm{yr}$ \\
Combined cycle plant capacity factor & $80 \mathrm{percent}$ & $80 \mathrm{percent}$ \\
Bio-oil fuel feed rate & 4.14 tonne/hr & $4.57 \mathrm{ton} / \mathrm{hr}$ \\
\hline
\end{tabular}

\subsection{Pyrolyzer Design}

This section describes in detail a fast pyrolysis process that converts a solid biomass waste, such as oat hulls and corn stover, into a liquid biofuel that can be used as a substitute for diesel oil or other hydrocarbon fuels to produce power in gas turbine engines and boilers. This technology has been developed and successfully demonstrated in DynaMotive Energy Systems pilot plants. The process utilizes a deep bubbling fluidized bed design combined with a novel bio-oil recovery system. The properties of bio-oil produced from agriculture biomass waste feedstock including oat hulls and forest residues such as bark and wood are given in detail, particularly in reference to their application as a fuel for gas turbine engines.

\subsubsection{Pyrolysis Introduction}

In the agricultural production process a substantial amount of the crop becomes a fibrous residue such as oat hulls, corn stover, and rice hulls. Traditionally, much of this solid waste product has been left in the field or incinerated in stationary boilers to produce steam for the process. As agricultural biomass often contains significant quantities of silica, its application as a fuel creates many operational problems due to 
both the glazing (fouling) of spreader stoker equipment and high temperature heat transfer surfaces and the accelerated erosion of steel tubing exposed to the abrasive particles in the flue gas. In addition, the fouling and high ash characteristics of combusted biomass prevent the direct use of the combustion products in direct fired gas turbines for efficient electrical generation. As a consequence, disposal of this residue has been problematic, inefficient and often expensive to the industry.

It is also a well-established fact that combustion of fossil fuels such as coal, oil and natural gas for power generation is a significant contributor to global warming (UNDP, 1999; IEA, 1996; Environment Canada, 1997). On the other hand biomass has long been identified as an alternate sustainable source of renewable energy (Yan et al., 1997). However, power generation using a solid fuel has had significant limitations with respect to materials handling requirements and efficient energy conversion. Converting biomass fuel into a liquid addresses these issues and makes possible the use of higher efficiency combined cycle systems for power generation. "Fast pyrolysis" technology is a unique process that converts solid biomass waste materials, such as oat hulls, into a relatively clean burning liquid fuel called bio-oil that is also carbon dioxide and greenhouse gas (GHG) neutral. The DynaMotive Energy Systems Corp. fast pyrolysis technology has proven to be a reliable and efficient technology for converting a wide range of biomass to a high energy density liquid fuel that handles like a heavy fuel oil.

The nearest term commercial application for bio-oil is as clean fuel for generating power and heat from small stationary diesel engines, gas turbines and boilers. DynaMotive Energy Systems Corp is working with Orenda Aerospace Corporation to test and develop bio-oil fuels for power generation (Fuleki et al., 2000) using their OGT 2500 gas turbine package, with an ISO rating of $2.85 \mathrm{MW}_{\mathrm{e}}$.

\subsubsection{Fast Pyrolysis of Biomass}

Fast pyrolysis (more accurately defined as thermolysis) is a process in which biomass material, such as oat hulls, is rapidly heated to high temperatures in the absence of oxygen. The oat hulls decompose into a combination of solid char, gas, vapors and aerosols. When cooled, most volatiles condense to a liquid referred to as "bio-oil". The remaining gases comprise a medium calorific value non-condensable gas.

Bio-oil is a liquid mixture of oxygenated compounds containing various chemical functional groups (Bridgewater et al, 1999; Gabra and Kjellstrom, 2002), such as carbonyl, carboxyl and phenolic. Bio-oil is made up of the following constituents: 20-25 percent water, 25-30 percent water-insoluble pyrolytic lignin, 5-12 percent organic acids, 5-10 percent non-polar hydrocarbons, 5-10 percent anhydrosugars and 10-25 percent other oxygenated compounds. 
DynaMotive Energy Systems Corp owns a specific fast pyrolysis technology (Morris, 1999) patented by its partner Resource Transforms International (RTI). This fast pyrolysis process is described in the patent titled, "Energy Efficient Liquefaction of Biomaterials by Thermolysis" (Piskorz et al.).

In this particular fast pyrolysis process, biomass feedstock is introduced into a thermolysis reactor having a bed of inert material, such as sand, with a height to width ratio greater than one. The biomass is shredded to sufficiently small dimensions so that its size does not limit significantly the production of the liquid product fraction. Simultaneous introduction of pre-heated, non-oxidizing gas at sufficient linear velocity performs two principal functions: firstly, as a medium for fluidizing the hot sand bed and secondly, to cause automatic elutriation of the product char from the fluidized bed reactor. The process includes removing the elutriated char particles from the effluent reactor stream and rapidly quenching the gas, aerosols and vapors to produce a high conversion yield of liquid bio-oil. For maximum yield of liquid, the thermolysis reaction must take place within a period of a few seconds at temperatures ranging from $450^{\circ} \mathrm{C}$ to $500^{\circ} \mathrm{C}$. The products must then be quenched as soon as possible to prevent cracking of the newly produced bio-oil.

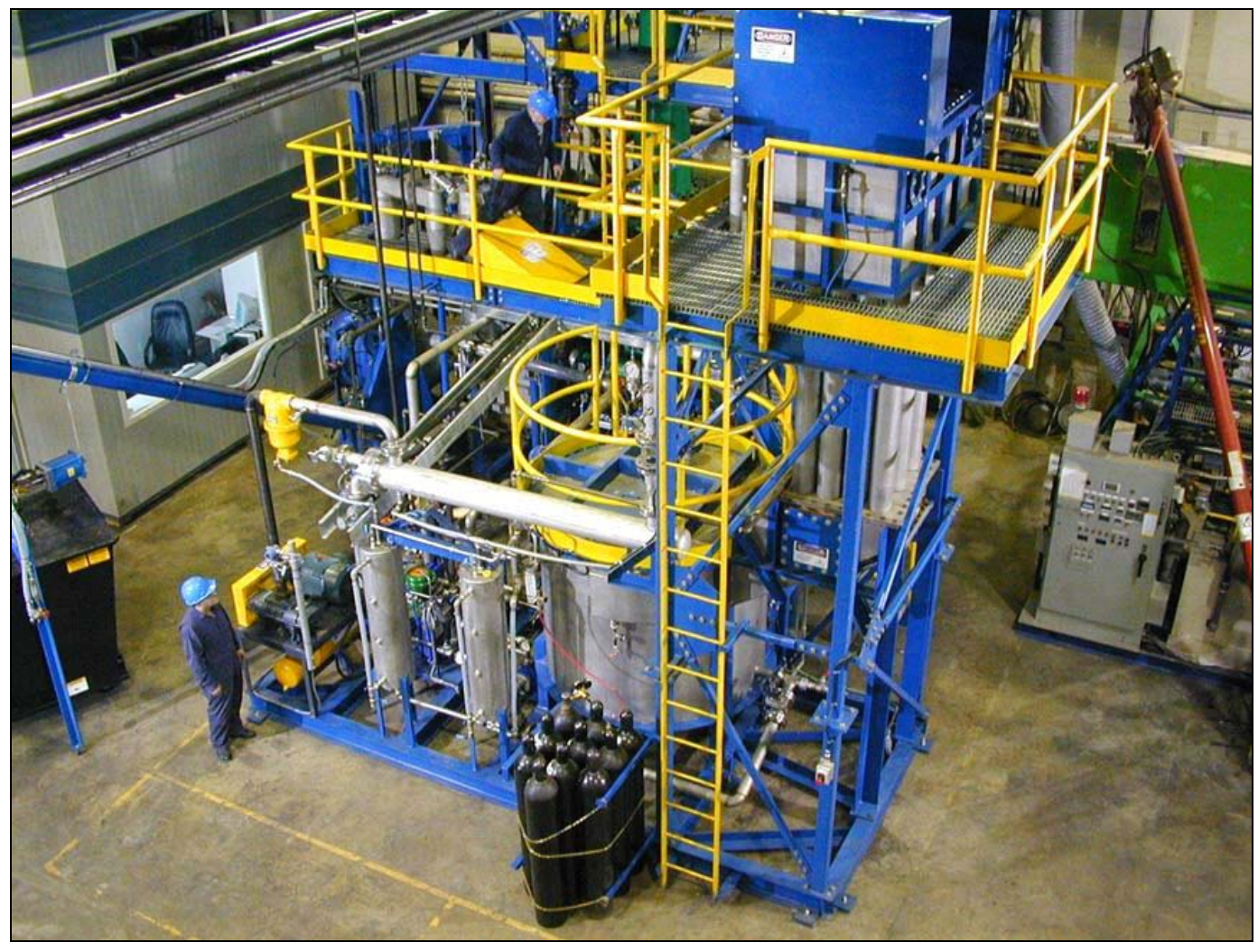

Figure 3-3. BioTherm ${ }^{\text {TM }} 15$ TPD Pilot Plant, Vancouver, BC. 


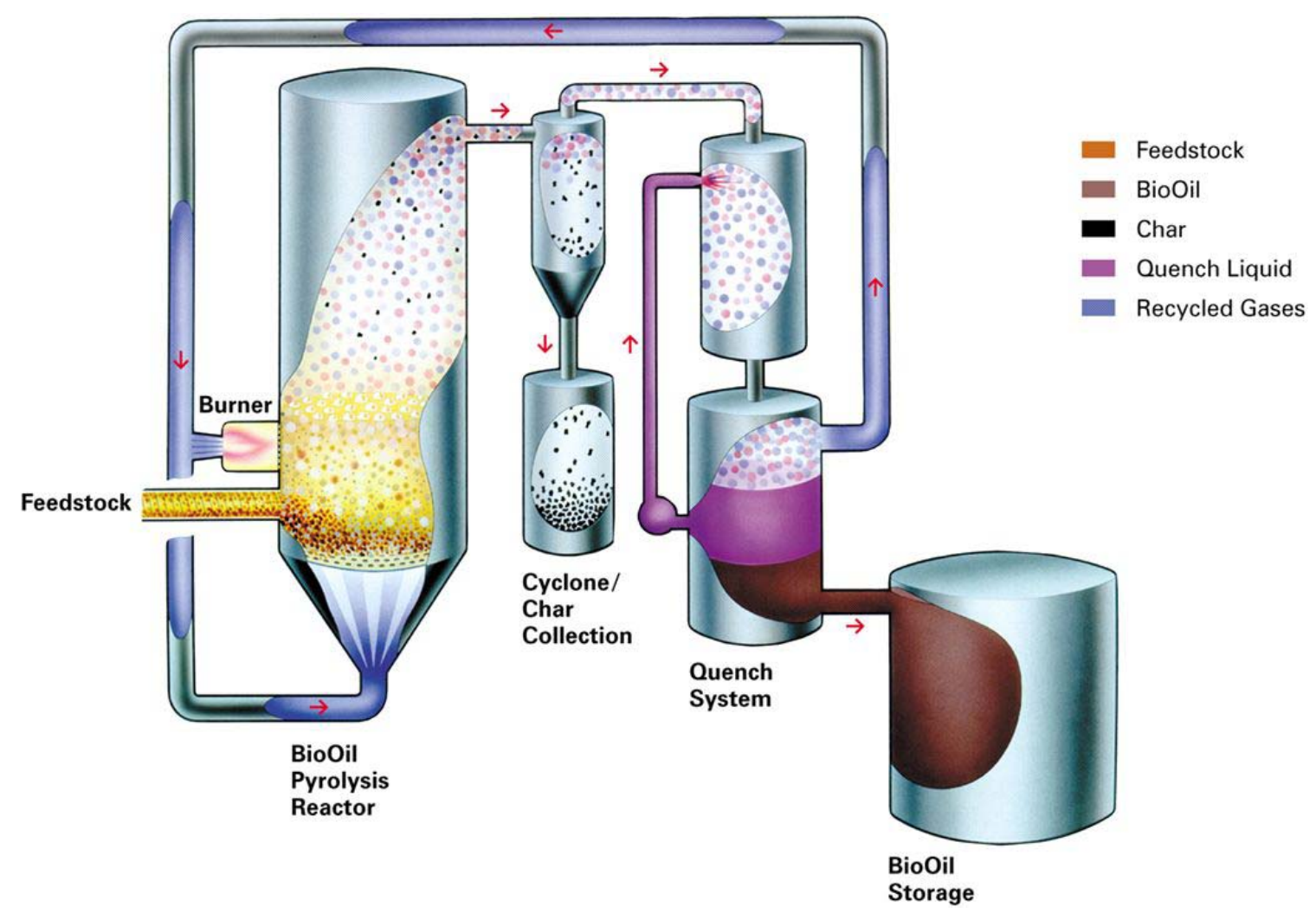

Figure 3-4. BioTherm ${ }^{\text {TM }}$ Flow Sheet.

\subsubsection{Fast Pyrolysis Heat and Mass Balance}

Feedstock for the fast pyrolysis process can be any biomass waste material including agricultural wastes and wood by-products. To maximize yield and minimize process development risk, DynaMotive has focused on near term bio-oil production from oat hulls, corn stover, sugarcane bagasse and wood waste (white wood and bark) feedstock. For the DOE Alliant Energy study the key biomass fuels under consideration are oat hulls and corn stover. The chemical properties of these two materials are sufficiently similar to enable them to be treated as the same for this level of analysis.

Preparation includes drying the feedstock to less than 10 percent moisture content to minimize the water content in the bio-oil and then grinding the feed to small particles to ensure rapid heat transfer rates in the reactor.

When processing bagasse feedstock, the conversion yield to liquid bio-oil, solid char and non-condensable gas is approximately 68 percent, 20 percent and 12 percent by weight, respectively, on an as fed basis. These yield rates were identical to those determined previously in laboratory size apparatus using the same operating conditions (Piskorz, 1999). For the oat hull and corn stover biomass the anticipated commercial yields are the conversion yield to liquid bio-oil, solid char and non-condensable gas is approximately 68 percent, 20 percent and 12 percent by weight, respectively, on an as fed 
basis. The dry ground oat hull material appears to be suitable for direct use as a pyrolysis feedstock for 68 percent bio-oil yield after additional hammer mill preparation. Depending on the moisture content of the as-received corn stover, additional drying may be necessary. However, for the purposes of this investigation, it is assumed that in-field and on site drying are sufficient to result in an "as-fired" moisture content of 10 percent or less. Further discussion of biomass properties are provided in Section 4, Fuel Supply Availability and Cost.

The heat required for thermolysis is the total heat that must be delivered to the reactor to provide all the sensible, radiation and reaction heat for the process to proceed to completion. The heat of reaction for the fast pyrolysis process is marginally endothermic. When operating the pilot plant using prepared feedstock, the total heat requirement to produce bio-oil at a 68 percent yield rate (including radiation and exhaust gas losses) is approximately $2.5 \mathrm{MJ}$ per kilogram of bio-oil produced. The net heat required from an external fuel source, such as natural gas, is only $1.0 \mathrm{MJ}$ per kilogram of bio-oil produced. This applies when the non-condensable gases produced in the process are directly injected into the reactor burner. This represents approximately 5 percent of the total calorific value of the bio-oil being produced.

To date the operation and scale-up of the DynaMotive BioTherm fast pyrolysis technology has shown very reliable, stable operation with predicable fuel characteristics and energy yield. The consistency of the BioTherm bio-oil products has been critical in long term stable handling characteristics of the bio-oil produced with this technology.

\subsubsection{Bio-Oil Analysis}

Bio-oil is a dark brown liquid that is free flowing. It has a pungent smoky odor. Bio-oil contains several hundred different chemicals with a wide-ranging molecular weight distribution.

The following Table 3-2 lists the properties of bio-oil produced by the BioTherm ${ }^{\mathrm{TM}}$ pilot plant, derived from three different biomass feedstocks.

The density of bio-oil is high, approximately $1.2 \mathrm{~kg} / \mathrm{liter}$. On a volumetric basis bio-oil has 55 percent of the energy content of diesel oil and 40 percent on a weight basis.

The solids entrained in the bio-oil principally contain fine char particles that are not removed by the cyclones. As can be seen, the solids in the bio-oil have been reduced significantly to levels of approximately 0.1 percent by weight. The ash content in these solids ranges from 2 percent to 20 percent, depending on the ash content in the feedstock.

Table 3-3 lists the chemical composition of major constituents in the bio-oil produced in the BioTherm ${ }^{\mathrm{TM}}$ process derived from different feedstock, namely bagasse, wood/bark, and wood. 
Table 3-2. DynaMotive Bio-Oil Properties.

\begin{tabular}{|c|c|c|c|}
\hline Biomass Feedstock & Bagasse & $\begin{array}{c}\text { Pine/Spruce } \\
\text { (53\% Wood + } \\
\text { 47\% Bark) }\end{array}$ & $\begin{array}{c}\text { Pine/Spruce } \\
\text { (100\% Wood) }\end{array}$ \\
\hline Moisture wt $\%$ & 2.1 & 3.5 & 2.4 \\
\hline Ash Content wt $\%$ & 2.9 & 2.6 & 0.42 \\
\hline \multicolumn{4}{|l|}{ Bio-Oil Properties } \\
\hline $\mathrm{pH}$ & 2.6 & 2.4 & 2.3 \\
\hline Water Content wt $\%$ & 20.8 & 23.4 & 23.3 \\
\hline Lignin $w t^{0} \%$ & 23.5 & 24.9 & 24.7 \\
\hline Solids Content wt $\%$ & $<0.10$ & $<0.10$ & $<0.10$ \\
\hline Ash Content wt $\%$ & $<0.02$ & $<0.02$ & $<0.02$ \\
\hline Density kg/L & 1.20 & 1.19 & 1.20 \\
\hline Calorific Value $\mathrm{MJ} / \mathrm{kg}$ & 15.4 & 16.4 & 16.6 \\
\hline Kinematic Viscosity, cSt $@ 20^{\circ} \mathrm{C}$ & 57 & 78 & 73 \\
\hline Kinematic Viscosity, cSt $@ 80^{\circ} \mathrm{C}$ & 4.0 & 4.4 & 4.3 \\
\hline
\end{tabular}

\begin{tabular}{|l|c|c|c|}
\hline \multicolumn{4}{|c|}{ Table 3-3. Bio-Oil Composition (Wt\%). } \\
\hline \hline Biomass Feedstock & Bagasse & $\begin{array}{c}\text { Pine/Spruce } \\
\text { (53\% Wood + } \\
\text { 47\% Bark) }\end{array}$ & $\begin{array}{c}\text { Pine/Spruce } \\
(\mathbf{1 0 0 \%} \text { Wood) }\end{array}$ \\
\hline Water & 20.8 & 24.3 & 23.3 \\
Lignin & 23.5 & 24.9 & 24.7 \\
Cellobiosan & - & 1.9 & 2.3 \\
Glyoxal & 2.2 & 1.9 & 2.3 \\
Hydroxyacetaldehyde & 10.2 & 10.2 & 9.4 \\
Levoglucosan & 3.0 & 6.3 & 7.3 \\
Formaldehyde & 3.4 & 3.0 & 3.4 \\
Formic Acid & 5.7 & 3.7 & 4.6 \\
Acetic Acid & 6.6 & 4.2 & 4.5 \\
Acetol & 5.8 & 4.8 & 6.6 \\
\hline
\end{tabular}




\subsubsection{Market Competitiveness}

In the proprietary DynaMotive process, bio-oil and char are commercial products and the non-condensable gases are recycled back into the process. No waste is produced in the DynaMotive process. The overall simplicity of the technology gives DynaMotive significant competitive advantages over other pyrolysis technologies in terms of capital and operating costs. DynaMotive's process also produces higher quality fuel and higher yields of bio-oil compared to competing technologies. This section provides an overview of the DynaMotive process production economics. A complete economic analysis of the overall system including the integrated pyrolysis portion is provided in Section 5, Economic Analysis.

DynaMotive has set a fully burdened production cost target of $\$ 3$ per gigajoule (GJ) of net plant output (US\$18.36 /BOE). This target was developed based on historic and current cost projections and an understanding of the potential optimizations yet to be realized in the current process.

Over the short term, these targets are expected to be met by concentrating on process optimization and minimizing expenses (e.g. low cost feedstocks, such as surplus agricultural biomass; heat recovery) and over the longer term by innovation and new technologies to balance increasing expenses (e.g. self generation, cutting edge drying technologies).

DynaMotive's target cost for bio-oil production is $\$ 3$ per gigajoule (GJ) of net plant output (US\$18.36 /BOE) based on a 400 tonne per day (tpd) commercial plant. The earliest and most appropriate market application for bio-oil is as a clean fuel to produce "green power" and heat in boilers, kilns, gas turbines and diesel engines. Over the past year, the company has established partnerships with gas turbine manufacturers (Orenda Aerospace, Solar/Caterpillar) to develop packaged bio-oil fueled gas turbine power systems and is collaborating with NRCan's CANMET combustion laboratory to develop burner nozzles for industrial boiler/kiln applications.

DynaMotive is also developing higher value fuel and chemicals applications for bio-oil including ethanol blended fuels, diesel/bio-oil emulsions and catalytic upgrading of bio-oil to synthesis gas, which can be converted to synthetic transport fuels and biomethanol for use in hydrogen fuel cells.

\subsubsection{Conclusions}

Converting biomass wastes produced from agriculture and forestry operations to a liquid bio-oil, using DynaMotive fast pyrolysis technology, has been demonstrated at the pilot plant level as a reliable and repeatable process. Test programs to demonstrate bio-oil application as a fuel in gas turbine engines, diesel engines and boilers are underway with 
a host of engine manufacturers. To date the results have been most encouraging for small scale, high efficiency conversion of biomass to electric power opportunities. For example, Figure 3-5 compares the efficiency of three biomass electricity generation options for a Tanzanian sugar mill. Use of gas turbine combined cycle as proposed in this study appears particularly promising.

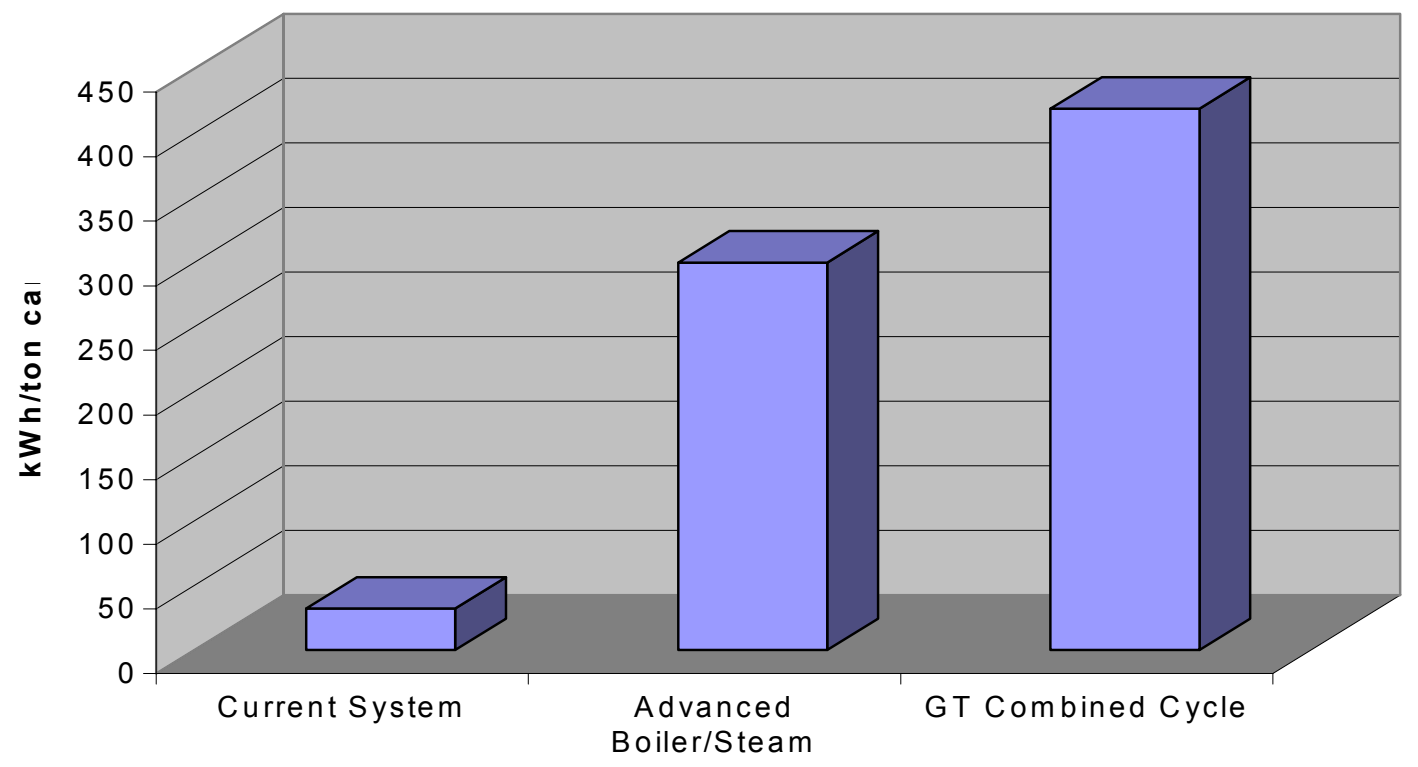

Figure 3-5. Comparison of Electrical Generating Options for a Tanzanian Sugar Mill (ref. Gabra and Kjellstrom).

\subsection{Fuel Clean-up Strategies}

Both pre and post-pyrolysis strategies were investigated to produce a suitable biooil feedstock for production of power and / or value-added chemicals. This section describes the technical and economic considerations of these systems.

\subsubsection{Technology}

Current systems for production of bio-oil yield products of only marginal quality as gas turbine fuel. Although pyrolytic products transported out of a pyrolyzer pass through a solids separator to remove char and ash from the gas flow, a significant quantity of particulate matter is often found in the condensed bio-oil. Most fast pyrolysis systems employ a gas cyclone to remove char and ash, which is inadequate for particulate matter finer than $10 \mu \mathrm{m}(33 \mu \mathrm{ft})$. The result is bio-oil containing fine char, which gives the liquid a characteristic dark brown or black color (Bridgwater et al., 1999). 
The fine char in bio-oil represents an undesirable contaminant. Char is reported to catalyze chemical reactions that degrade pyrolysis liquids and promotes polymerization (Agblevor et al., 1995; Diebold et al., 1996). This char also interferes with atomization of bio-oil when injected into gas turbine combustors, which extends vaporization and burnout times of the fuel. Furthermore, alkali in biomass becomes concentrated in char upon pyrolysis (Diebold et al., 1996). Alkali can produce corrosion of gas turbine blades at even very low concentrations.

Both pre-pyrolysis and post-pyrolysis strategies for removing contaminants from the bio-oil were investigated. The pre-pyrolysis strategy consists of removing alkali by washing the biomass. Even rinsing biomass with water has proved effective in removing alkali, which exists in water-soluble form (Dayton et al., 1999; Turn et al., 1997). However, since removal of char also removes most of the alkali, the washing strategy was not pursued as a means of contaminant control. On the other hand, it is an integral element in the production of certain high-value products, as described in the section on recovery of chemicals from bio-oil. The rest of this section focuses on filtration of char from bio-oil as a dual-contaminant control strategy.

Although removal of char from bio-oil will simultaneously solve the particulate and alkali contamination problems, bio-oil is not readily filtered because the organic compounds in the liquid tend to clump around the char particles (Elliott, 1994). More effective is hot gas clean up of gases and vapors exiting the pyrolyzer.

DynaMotive includes a high efficiency cyclone in its standard pyrolysis plant design, and this system was included as part of the base case conceptual design of the IPCC plant. If further removal of char is necessary, alternate methods are available. For example, experiments have shown that a ceramic candle filter operating at temperatures above the condensation points of the pyrolysis vapors effectively removes fine char. Ash content as low as 0.01 percent and alkali content as low as $3 \mathrm{ppm}$ have been obtained by vapor filtration of bio-oil at $400^{\circ} \mathrm{C}\left(752^{\circ} \mathrm{F}\right)$ (Diebold, 1996). However, long-term operation of candle filters for this purpose is problematic. Pyrolytic char is cohesive and the resulting dust cake is not readily removed from surface of a ceramic candle filter.

A more promising approach to hot vapor filtration may be the use of a moving bed granular filter. These filters pass hot, dirty gas through a bed of refractory granules, where fine particulate matter impacts and adheres to the granules. The granules continuously flow downward by gravity through the bed, removing the dirty granules and replacing them with fresh media (Saxena et al., 1985). Thus, even moderately cohesive dust will flow out of the filter without fouling the filter.

Iowa State University has developed a moving bed granular filter (MBGF) for dry scrubbing of product gas from biomass gasifiers, which may prove suitable for hot 
filtration of pyrolytic vapors. In this filter, illustrated in Figure 3-6, granular material moving downward by gravity spills from a centrally located dipleg to form an interfacial region where dust cake forms and most particulate removal occurs. The lower edge of the filter cake is dispersed by the downward flow of granular material while the upper interface is continuously covered by a fresh layer of granular material cascading from the dipleg above the interface. In this fashion, the interface establishes a dust cake of quasisteady thickness, which is controlled to give high collection efficiency and acceptable pressure drop. Details of the filter construction and operation are found in Brown et al. (2000). Recent cold-flow evaluations of the filter yielded particulate removal efficiencies exceeding 99 percent (Colver et al., 2002). Iowa State University is presently constructing a MBGF to operate on the hot vapors from a fast pyrolysis pilot plant.

\subsubsection{Economics}

The base conceptual design includes a high efficiency cyclone as a standard component for char removal. Its cost is nominal and is included in the overall pyrolysis plant cost estimate described in Section 5.

Moving bed granular filters are not commercially available at this time. However, Energy Products of Idaho (EPI), which is evaluating the commercial potential for this kind of filter, estimates that a unit designed for $606 \mathrm{~m}^{3} / \mathrm{min}(21,400 \mathrm{acfm})$ of gas will cost $\$ 400,000$. The pyrolysis power system proposed in the present study, processing $5,390 \mathrm{~kg}$ of biomass $/ \mathrm{h}$, would be considerably smaller than the unit being evaluated by EPI. The flow rate of pyrolytic vapors and gases is estimated as follows:

Approximately 15 percent of the feedstock is converted into non-condensable gases; application of the ideal gas law at the pyrolysis temperature of $450^{\circ} \mathrm{C}\left(840^{\circ} \mathrm{F}\right)$ and atmospheric pressure indicates at non-condensable gas flow of $28 \mathrm{~m}^{3} / \mathrm{min}(1003 \mathrm{acfm})$. Using the rule of thumb that the flow rate of condensable vapors is approximately three times that of non-condensable gases, yields an approximate volumetric flow rate through the hot filter of $84 \mathrm{~m}^{3} / \mathrm{min}$ (3009 acfm). 


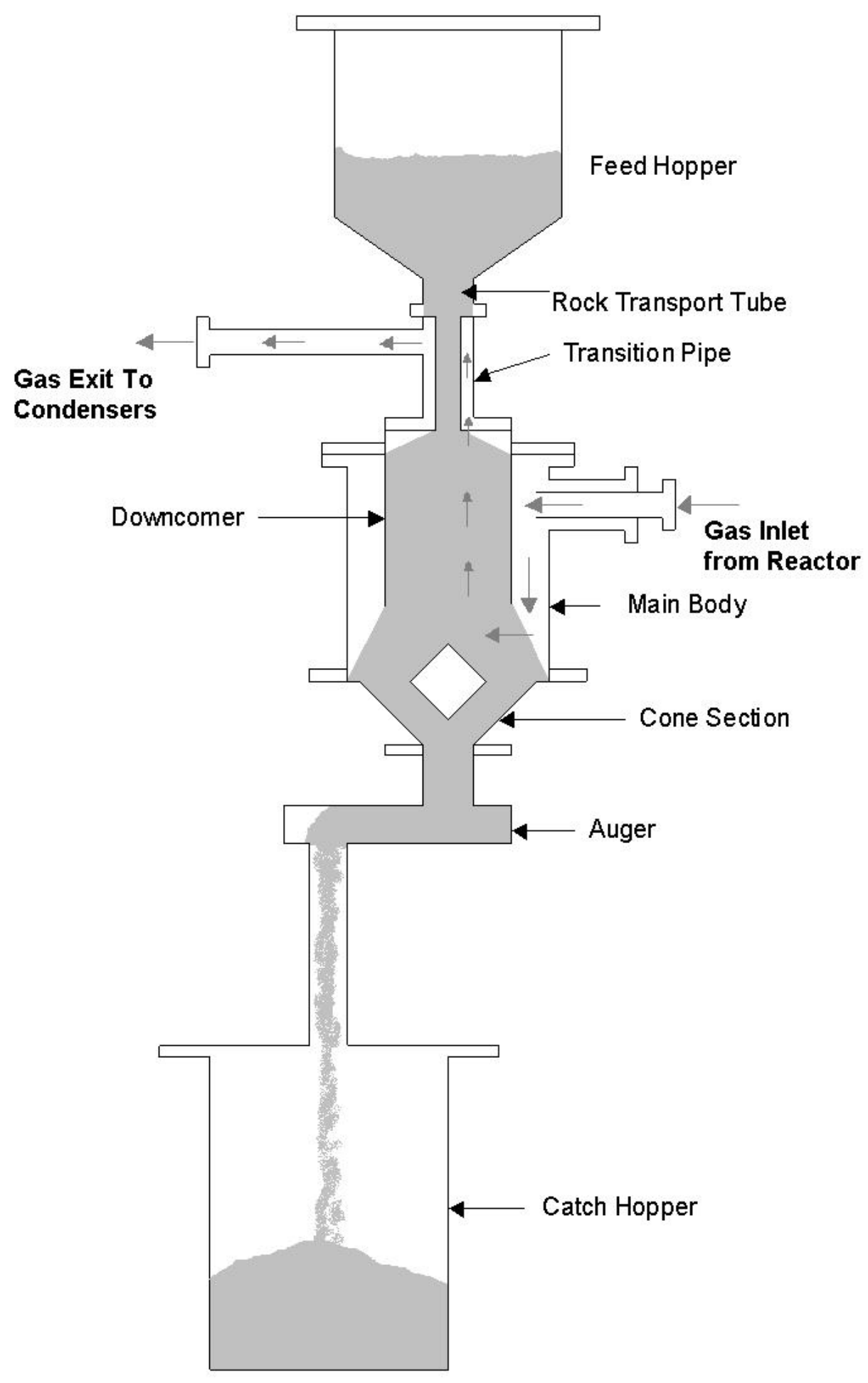

Figure 3-6. Moving Bed Granular Filter for Removing Particulate Matter from Pyrolysis Vapors. 
Applying the "sixth-tenths" scaling rule suggests that the cost of a moving bed granular filter for a $5,390 \mathrm{~kg} / \mathrm{h}(12,077 \mathrm{lb} / \mathrm{h})$ plant will be:

$$
C=\$ 400,000(84 / 606)^{0.6}=\$ 122,220 \text { (Free on Board or f.o.b) }
$$

This does not include installation costs, which are conservatively estimated by the methodology outlined in Table 3-4 (Ulrich, 1984). Inclusion of these costs results in a total module cost of $\$ 294,000$ for the moving bed granular filter.

\subsection{Pyrolysate Condenser Design}

Many commercial and pilot-plant pyrolysis systems employ a wet scrubber or quench system to recover pyrolysis liquid from the gas stream exiting the solids separator. In this case, cold pyrolysis liquid is sprayed into the hot gas stream entering the scrubber/quencher, cooling the gas and forcing pyrolysis vapors to condense on droplets of cold liquid. Essentially all the heat added to the pyrolyzer at $400-500^{\circ} \mathrm{C}$ $\left(752-932^{\circ} \mathrm{F}\right)$ is recovered here as low quality heat at temperatures below $100^{\circ} \mathrm{C}$ $\left(212^{\circ} \mathrm{F}\right)$. This approach is wasteful from the perspective of integrated energy management and does not allow separation of different compounds from the bio-oil since they are all condensed in a single chamber. In addition to the standard quench condenser included in the base case conceptual design, two alternative approaches to collecting condensate were explored: one proposed by Iowa State University and the other by DynaMotive. These are each discussed in the following paragraphs.

\subsubsection{Staged Condenser}

Iowa State is investigating the feasibility of a pyrolysate condenser, which employs several water-cooled condensers in series to gradually cool the hot vapors exiting the fast pyrolysis reactor. The concept offers the possibility of recovering thermal energy at temperatures well above $100^{\circ} \mathrm{C}\left(212^{\circ} \mathrm{F}\right)$ as well as selectively condensing compounds in different sections of the condenser. This work, supported by the Iowa Energy Center, has not yet been published. However, preliminary results are reported here. 
Table 3-4. Summary of Methodology for Capital Cost Calculations.

\begin{tabular}{|c|c|c|}
\hline Cost & Calculation & Description \\
\hline \multicolumn{3}{|l|}{ Direct Project Expenses } \\
\hline Equipment (f.o.b.) & $\mathrm{C}_{\mathrm{p}}$ & $\begin{array}{l}\text { "Free on board" or f.o.b- } \\
\text { cost when placed aboard the } \\
\text { shipping carrier. Obtained } \\
\text { from suppliers or estimated } \\
\text { from tabulations of purchased } \\
\text { equipment costs or installed } \\
\text { bare module costs (Blazej et } \\
\text { al., 1993) Adjusted for size } \\
\text { and inflation. }\end{array}$ \\
\hline Materials for installation & $\mathrm{C}_{\mathrm{M}}=\mathrm{MMF} \times \mathrm{C}_{\mathrm{p}}$ & $\begin{array}{l}\text { Based on tabulated materials } \\
\text { module factors (MMF) found } \\
\text { in References } 1 \text { and } 2 \text {; } \\
\text { expressed as fraction of } C_{p}\end{array}$ \\
\hline Direct Labor & $\mathrm{C}_{\mathrm{L}}=\mathrm{LMF} \times\left(\mathrm{C}_{\mathrm{p}}+\mathrm{C}_{\mathrm{M}}\right)$ & $\begin{array}{l}\text { Based on tabulated labor } \\
\text { module factors (LMF) in } \\
\text { (Agblevor et al., 1995) and } \\
\text { (Bridgewater et al., 1999); } \\
\text { expressed as fraction of } \\
C_{\mathrm{P}}+C_{M}\end{array}$ \\
\hline TOTAL DIRECT & $\mathrm{C}_{\mathrm{D}}=\mathrm{C}_{\mathrm{P}}+\mathrm{C}_{\mathrm{M}}+\mathrm{C}_{\mathrm{L}}$ & \\
\hline \multicolumn{3}{|l|}{ Indirect Project Expenses } \\
\hline Freight, insurance, taxes & $\mathrm{C}_{\mathrm{FIT}}=0.08 \mathrm{C}_{\mathrm{P}}$ & $\begin{array}{l}\text { Estimated as } 8 \text { percent of } \\
\text { total purchased equipment } \\
\text { costs }\end{array}$ \\
\hline Construction overhead & $\mathrm{C}_{\mathrm{O}}=0.7 \mathrm{C}_{\mathrm{L}}$ & $\begin{array}{l}\text { Estimated as } 70 \text { percent of } \\
\text { total labor installation costs }\end{array}$ \\
\hline Engineering expenses & $\mathrm{C}_{\mathrm{E}}=0.15\left(\mathrm{C}_{\mathrm{P}}+\mathrm{C}_{\mathrm{M}}\right)$ & $\begin{array}{l}\text { Estimated as } 15 \text { percent of } \\
\text { total equipment and materials } \\
\text { costs }\end{array}$ \\
\hline TOTAL INDIRECT & $\mathrm{C}_{\mathrm{ID}}=\mathrm{C}_{\mathrm{FIT}}+\mathrm{C}_{\mathrm{O}}+\mathrm{C}_{\mathrm{E}}$ & \\
\hline BARE MODULE COST & $\mathrm{C}_{\mathrm{BM}}=\mathrm{C}_{\mathrm{D}}+\mathrm{C}_{\mathrm{ID}}$ & $\begin{array}{l}\text { Defined as combined direct } \\
\text { and indirect costs }\end{array}$ \\
\hline Contingency \& fee & $\mathrm{C}_{\mathrm{CF}}=0.18 \mathrm{C}_{\mathrm{BM}}$ & $\begin{array}{l}\text { Estimated at } 18 \text { percent of } \\
\text { bare module cost }\end{array}$ \\
\hline TOTAL MODULE COST & $\mathrm{C}_{\mathrm{TM}}=\mathrm{C}_{\mathrm{BM}}+\mathrm{C}_{\mathrm{CF}}$ & $\begin{array}{l}\text { Defined as bare module cost } \\
\text { plus contingency and fee }\end{array}$ \\
\hline
\end{tabular}


The four-stage condenser is illustrated in Figure 3-7. Typical gas temperatures and catches of bio-oil for each stage are indicated on the drawing. Although quantitative analyses have not been performed on the bio-oils collected with this condenser system, qualitative differences among the four stages were evident. The first stage, which operates above the condensation temperature for water, is very viscous, indicating that it contains very little liquid water. In some trials, the bio-oil from the first stage of condensation is so viscous that it cools to a solid in the collection jar. Only about 5 percent of the bio-oil condenses in this stage. Careful design of this first stage of condensation, which employs a single, large diameter tube rather than several small diameter tubes, can prevent plugging of the condenser. The third stage, on the other hand, yields bio-oil of very low viscosity, which suggests that much of the water condenses from the gas flow at this point. Future work will quantify the distribution of water and organic compounds collected from each stage of condensation. The overall condenser was able to collect 75 percent of the total bio-oil yield, which is better than many spray quenchers used commercially.

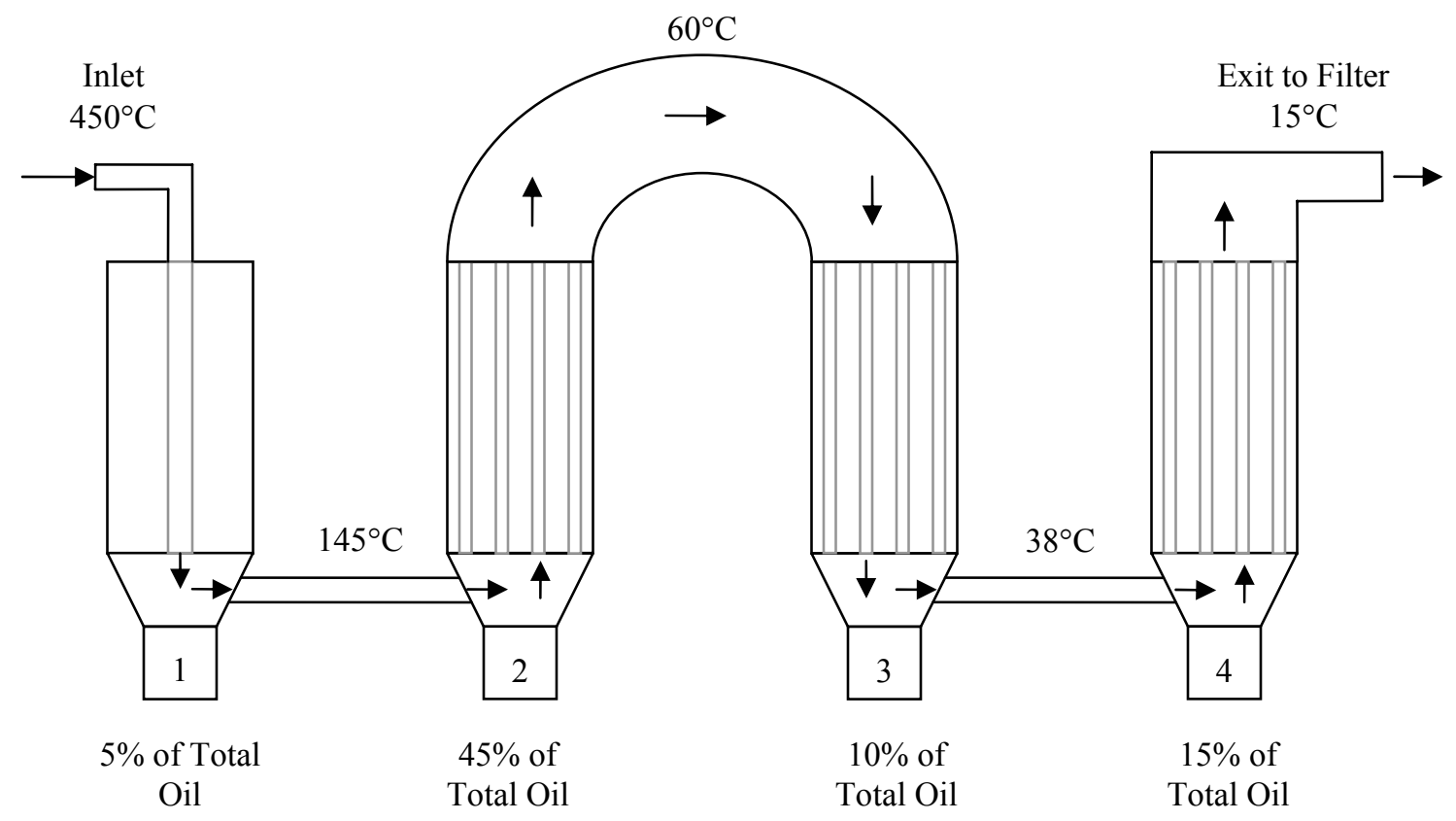

Remaining $25 \%$ of Total Oil collected in Filter

Figure 3-7. Pyrolysis Condensers: Water Cooled Shell-in-Tube Design. 
This research showed that levoglucosan, of which the potential as a value-added product is discussed in the next section, was concentrated to 46 weight-percent in the first stage of a four-stage condenser while the second stage contained only 18 weight-percent of levoglucosan. Enrichment occurred despite the lack of careful temperature control at condensation surfaces. This approach to separation of pyrolysis products takes its inspiration from "integral reactive distillation" in which products are removed in-situ before side reactions can occur that produce undesirable products (Garside, 1994).

The original reason for investigating the staged condenser was to recover waste heat for use in feedwater heaters in the bottoming steam cycle. However, analysis of the power cycle dismissed the value of this waste heat for this purpose and the focus of the pyrolysate condenser turned to recovery of chemicals from the bio-oil. DynaMotive suggested the use of a fractionating quencher rather than the staged condenser envisioned by Iowa State University. The fractionating quencher, described in the following paragraphs, allows some recovery of organic chemicals and a relatively modest amount of low temperature waste heat.

\subsubsection{Fractionating Quencher}

The change in character on demineralization of biomass can be appreciated from Table 3-5, which compares the bio-crude oil (BCO) from untreated and demineralized softwood. The latter has a substantially lower content of low molecular weight carbonyls resulting in a $\mathrm{BCO}$ of greatly diminished volatility (a fact which also has implications for pyrolyzer performance). Gas yields are also dramatically lower. Similar changes upon demineralizing corn stover are evident in Table 3-6.

Some additional points of note:

- When the BCO is hydrolyzed to convert anhydrosugars to free sugars, the glucose equivalent yield of fermentable sugars is appreciably greater than that calculated on the basis of monomers (levoglucosan/anhydromannose) and dimers (cellobiosan) listed. Further, this is apart from the automatic 11 percent weight gain of glucose over levoglucosan. Thus the sugars listed in the table underestimate the total fermentable sugar yield.

- Although acetic acid is low for this feedstock, in some cases in can be as high as $6-10$ percent. 
Table 3-5. Pyrolysis Products for Woody Biomass (Bone-Dry Western Hemlock; Reaction Temperatures $450-490^{\circ} \mathrm{C}\left(842-914^{\circ} \mathrm{F}\right)$.

\begin{tabular}{|l|c|c|}
\hline \hline Pretreatment & None & De-mineralization \\
Additive & None & 0.1 percent $\left(\mathrm{NH}_{4}\right)_{2} \mathrm{SO}_{4}$ \\
Hexosan Content of Feed (weight percent) & $\sim 62$ & $\sim 62$ \\
Yields (weight percent of feed) & 12.0 & 5.1 \\
Gas & 18.2 & 17.3 \\
Coke/Char & 65.9 & 74.2 \\
BCO & & \\
BCO Composition (weight percent): & 14.3 & 12.8 \\
Water & 0.5 & 2.6 \\
Cellobiosan & 2.4 & 16.8 \\
Levoglucosan & 0.0 & 5.3 \\
Anhydromannose & 10.6 & 2.2 \\
Glycolaldehyde & 1.4 & 1.6 \\
Acetic Acid & 7.4 & $\sim 0$ \\
Other C $\mathrm{C}_{3}$ Oxo Compounds & 19.9 & 21.6 \\
Pyrolytic Lignin & 3 & 33 \\
Percent Hexosan Conversion to Sugars &
\end{tabular}

Table 3-6. Pyrolysis Products for Herbaceous Biomass (Bone-Dry Corn Stover; Reaction Temperatures $450-490^{\circ} \mathrm{C}\left(842-914^{\circ} \mathrm{F}\right)$.

\begin{tabular}{|l|c|c|}
\hline Pretreatment & None & $\begin{array}{c}\text { De-mineralization } \\
\text { Additive }\end{array}$ \\
Yields (weight percent of feed) & None & \\
$\quad$ Gas & 22.6 & 7.9 \\
Coke/Char & 15.8 & 13.2 \\
BCO & 61.6 & 78.9 \\
BCO Composition (weight percent) & & \\
Water & $\sim 4.2$ & 13.2 \\
Cellobiosan & Trace & 3.3 \\
Levoglucosan & 2.8 & 20.1 \\
Glycolaldehyde & 11.6 & 3.7 \\
Acetic Acid & 3.4 & 1.3 \\
Pyrolytic Lignin & $\sim 33.4$ & 17.7 \\
\hline
\end{tabular}


The following is a first proposal for a scheme to recover these chemicals together with the potential to recover heat. It should be understood that this is hardly a definitive proposal as there are many associated uncertainties. Some specific examples are:

- Boiling points of various specific compounds and condensate fractions are highly uncertain. These will have to be established more definitively by experimentation.

- On account of the reactive nature of fresh bio-oil, subjecting it to repetitive heating and cooling sequences could cause irreversible changes in its physicochemical properties that render some aspect of the scheme inoperable; for example by forming polymeric materials that cause fouling of surfaces.

- The viscosity of the various condensate fractions could play an important role in the possible designs for heat exchangers. While there are published studies of viscosity of whole bio-oil and an identification of some of the factors that influence it, the available information is insufficient to predict the rheological properties of specific fractions.

- The question is whether one can one build a column that is efficient and has low residence times (to minimize secondary reactions to which the $\mathrm{BCO}$ is prone). The high stability of the aerosols is problematic as are the low diffusion coefficients in viscous liquid fractions.

With these caveats, the proposed design, shown in Figure 3-8, is based on the following considerations:

- The irreversible nature of $\mathrm{BCO}$ vaporization suggest that we attempt to fractionate it during the cooling process rather than by re-boiling, using the sensible heat of the pyrolyzer effluent as the driving force for fractionation rather than through a reboiler.

- Unfortunately levoglucosan appears to have a boiling point that partially overlaps those of some of the higher MW phenolic monomers. This is not necessarily a serious problem as the phenols, unlike the anhydrosugars, have low water solubility. However this aspect is neglected in the proposed scheme.

- The aqueous overhead condensate is re-mixed with the bottoms (largely pyrolytic lignin) to restore lower viscosity.

- This mixture is adjusted to a proper temperature and injected into the column above the entry point of the $\mathrm{BCO}$ vapors at a rate sufficient to lower the temperature from about $480^{\circ} \mathrm{C}\left(896^{\circ} \mathrm{F}\right)$ to about $300^{\circ} \mathrm{C}\left(572^{\circ} \mathrm{F}\right)$. 


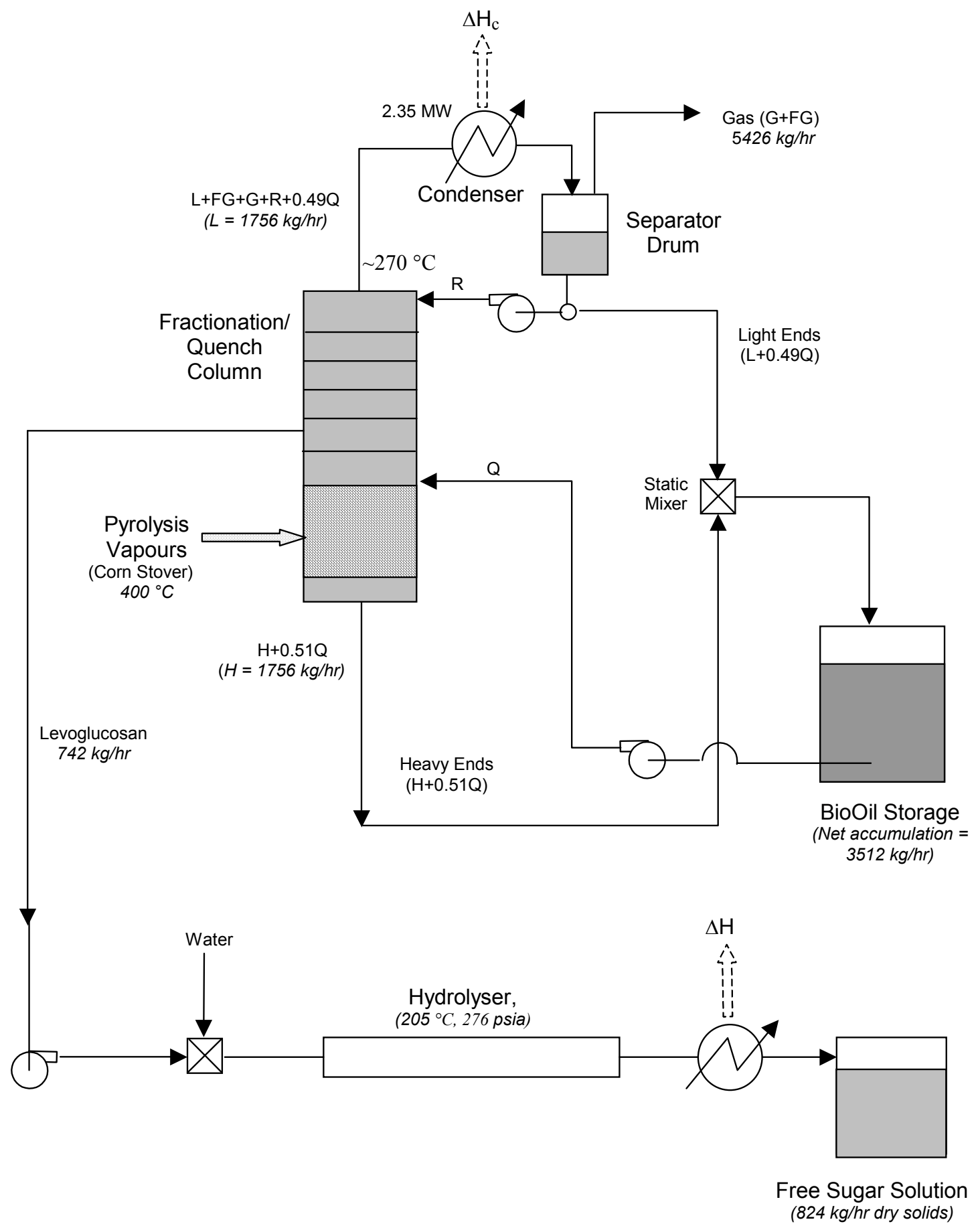

Figure 3-8. Concept for Fractionating Quencher. 
- Optionally the difference in solubility of the pyrolytic lignin and anhydrosugars in water can be exploited by extracting the bottoms from the column with water to remove oligomeric sugars of low volatility.

Assuming the raw biomass material is de-mineralized corn stover, a rate of $5,390 \mathrm{~kg} / \mathrm{h}(11,883 \mathrm{lb} / \mathrm{h})$ of corn stover to the pyrolyzer will generate $(0.789+0.079) \times 5,390=4,679 \mathrm{~kg} / \mathrm{h}(10,316 \mathrm{lb} / \mathrm{h})$ of volatiles $(\mathrm{V}) . \quad$ The volatiles comprise gas (G) at $426 \mathrm{~kg} / \mathrm{h}(938 \mathrm{lb} / \mathrm{h})$, water $(\mathrm{W})$ at $562 \mathrm{~kg} / \mathrm{h}(1,240 \mathrm{lb} / \mathrm{h})$ and organics (O) at 3,692 kg/h $(8,139 \mathrm{lb} / \mathrm{h})$.

$$
\mathrm{V}=\mathrm{W}+\mathrm{G}+\mathrm{O}
$$

In view of the uncertainties mentioned above, we shall apply a highly simplified scheme in which it will be assumed that the bio-oil is composed of the following components:

- The heavy fraction is composed mainly of pyrolytic lignin (PL)

- Levoglucosan (LG)

- A residual light fraction boiling below $300^{\circ} \mathrm{C}\left(572^{\circ} \mathrm{F}\right)$

- A residual heavy fraction boiling above $300^{\circ} \mathrm{C}\left(572^{\circ} \mathrm{F}\right)$

The residual organics exclusive of LG and PL will be arbitrarily assumed to be divided equally between light and heavy fractions, that is, we write for the total light (L) and heavy $(\mathrm{H})$ fractions, respectively:

$$
\begin{aligned}
& \mathrm{L}=\mathrm{W}+1 / 2(\mathrm{O}-\mathrm{LG}-\mathrm{PL})=1,711 \mathrm{~kg} / \mathrm{h}(3,751 \mathrm{lb} / \mathrm{h}) \\
& \mathrm{H}=\mathrm{PL}+1 / 2(\mathrm{O}-\mathrm{LG}-\mathrm{PL})=1,824 \mathrm{~kg} / \mathrm{h}(3,978 \mathrm{lb} / \mathrm{h}) \\
& \mathrm{LG}=742 \mathrm{~kg} / \mathrm{h}(1,639 \mathrm{lb} / \mathrm{h}), \\
& \text { so that overall, the total bio-oil (B) is divided into: } \\
& \mathrm{B}=\mathrm{LG}+\mathrm{H}+\mathrm{L} .
\end{aligned}
$$

After separation of LG, the stored part of the bio-oil is $\mathrm{H}+\mathrm{L}$. The boiling points of $\mathrm{L}$ and $\mathrm{H}$ will also be arbitrarily assumed to be $120^{\circ} \mathrm{C}\left(248^{\circ} \mathrm{F}\right)$ and greater than $300^{\circ} \mathrm{C}$ $\left(572^{\circ} \mathrm{F}\right)$ respectively.

For simplicity, the numerical values of the material flows shown in the process diagram assume that the only chemical recovered is levoglucosan - no phenols, acetic acid or other light fractions; however, as pointed out earlier, we believe that a high valued phenolic fraction could be easily recovered.

Levoglucosan production rate is $742 \mathrm{~kg} / \mathrm{h}(1,639 \mathrm{lb} / \mathrm{h})$ assuming 100 percent recovery efficiency. Since hydrolysis to free sugars involves the addition of a water 
molecule to each LG molecule, this would correspond to a production rate of $824 \mathrm{~kg} / \mathrm{h}$ $(1,811 \mathrm{lb} / \mathrm{h})$ of free sugars.

Katritzky et al (1996) have described what appears to be a cheap and simple method that involves nearly stoichiometric hydrolysis of levoglucosan with high-pressure water. They report that a 0.30 Molar aqueous solution of LG was quantitatively converted to predominantly glucose and traces of another glucose isomer at $205^{\circ} \mathrm{C}$ and $1,906 \mathrm{kPa}\left(401^{\circ} \mathrm{F}\right.$ and $\left.276 \mathrm{psi}\right)$ so the required conditions are relatively mild and thus, such a process step would be expected to be rather inexpensive. We show this operation as a simple heat exchange.

Cellobiosan (C), which is a dimer of levoglucosan, is expected to appear in $\mathrm{H}$. We show on the process diagram a water extraction of the cooled heavy fraction to remove $\mathrm{C}$ and accumulate it with LG. This is tentative since although PL is insoluble in water, it would be surprising if there were not other components of $\mathrm{H}$ that are. In that case a simple water extraction without additional clean up (lime, adsorption, etc.) to remove potentially bio-toxic compounds may not be practical. Recovery of $\mathrm{C}$ would provide an additional $122 \mathrm{~kg} / \mathrm{h}(270 \mathrm{lb} / \mathrm{h})$ of hydrolysable sugars or $136 \mathrm{~kg} / \mathrm{h}(302 \mathrm{lb} / \mathrm{h})$ of fermentable sugars.

A reflux stream $\mathrm{R}$ composed of light ends controls the upper temperature of the fractionator temperature while a quench stream $\mathrm{Q}$ composed of the components in the stored bio-oil controls the lower temperatures. The stored bio-oil is comprised of the primary oil less the anhydrosugars. Its composition is thus 49 percent $\mathrm{L}$ and 51 percent H.

The magnitudes of the various heat transfer operations in the indicated directions are denoted by $\Delta \mathrm{H}_{\mathrm{i}}$. We have not shown any coupling between these various heat flows as there is too much uncertainty at the present time. However the net heat available from the process would be

$$
\Delta \mathrm{H}_{1}+\Delta \mathrm{H}_{2}+\Delta \mathrm{H}_{3}-\Delta \mathrm{H}_{4}-\Delta \mathrm{H}_{5}
$$

Of course not all of this is available at the same temperature. For example, $\Delta \mathrm{H}_{1}$ and $\Delta \mathrm{H}_{2}$ are available at about $300^{\circ} \mathrm{C}\left(572^{\circ} \mathrm{F}\right)$ but $\Delta \mathrm{H}_{3}$ is available at only about $120^{\circ} \mathrm{C}$ $\left(248^{\circ} \mathrm{F}\right)$. In view of the uncertainties in heats of evaporation of the various fractions it is perhaps not very meaningful to speculate on the total available heat at this time. However, using a published (Oasmaa and Peacocke, 2001) heat capacity for bio-oil of $3.2 \mathrm{~kJ} / \mathrm{kg}-\mathrm{K}(0.7 \mathrm{Btu} / \mathrm{lb}-\mathrm{F})$ (strictly applicable only to the range $26-61^{\circ} \mathrm{C}$ or $\left.78-142^{\circ} \mathrm{F}\right)$, and so considering only the sensible heat, and also using a baseline reference temperature of $20^{\circ} \mathrm{C}\left(68^{\circ} \mathrm{F}\right)$, we find that $2,280 \mathrm{MJ} / \mathrm{h}(2.2 \mathrm{MBtu} / \mathrm{h})$ (i.e. from $\left.\mathrm{LG}+\mathrm{H}\right)$ would be 
available at about $300^{\circ} \mathrm{C}\left(572^{\circ} \mathrm{F}\right)$ and $683 \mathrm{MJ} / \mathrm{h}(0.65 \mathrm{MBtu} / \mathrm{h})($ i.e. from $\mathrm{L}+\mathrm{G})$ would be available at about $120^{\circ} \mathrm{C}\left(248^{\circ} \mathrm{F}\right)$.

These may be compared with the net heat required for pyrolysis which is, very roughly, just the sensible heat required to raise the biomass feed to the pyrolysis temperature, namely about 5,390 MJ/h $(5.39 \mathrm{MBtu} / \mathrm{h})$ at about $480^{\circ} \mathrm{C}\left(896^{\circ} \mathrm{F}\right)$. Thus, roughly half of the input heat could be recovered usefully under the conditions stated in the previous paragraph.

It is clear that substantial additional experimental work will be required to make more definitive statements.

\subsection{Opportunities for Recovering Pyrolysis Byproducts}

As discussed in the introduction to this section, the project team has proposed two conceptual designs for this project:

- Maximum Power Production Design

- Value-Added Chemicals Design

Previous sections have discussed the implementation of fuel clean-up strategies and advanced pyrolysate condenser designers as optional equipment to the base case IPCC cycle design (that is, maximum power production design). The intent of this additional equipment is to target recovery of value-added chemicals, primarily the organic components of the bio-oil (and in particular anhydrosugars). In addition, the carbonaceous solid char recovered from the hot vapor filtration system is a potential feedstock for production of activated carbon. This section explores in further detail the opportunities for recovery of these byproducts.

\subsubsection{Recovery of Activated Carbon from Pyrolysis Char}

The proposed pyrolyzer is estimated to generate char at the rate of $776 \mathrm{~kg} / \mathrm{h}$ $(1,711 \mathrm{lb} / \mathrm{h})$. With a heating value of $23.3 \mathrm{GJ} / \mathrm{t}(20.0 \mathrm{MBtu} / \mathrm{t})$, this could provide significant energy to the steam turbine bottoming cycle. If not used on site, the fuel might also make an attractive boiler fuel for co-firing at existing coal fired power plants. However, potentially more lucrative is activation of the char with steam to yield about half the weight of char as an inexpensive sorbent (Scott et al., 1999). This byproduct, which already sequesters the original alkali content of the biomass feedstock, could be marketed as an activated carbon sorbent for the control of mercury emissions from coalfired power plants. As part of this project, chars produced from the pyrolysis of corn stover and oat hulls was characterized and activated, as described in the following paragraphs. 


\subsubsection{Preparation and characterization of chars}

The biomass used to produce the char was pyrolyzed in the system shown in Figure 3-9. The tested biomass materials used in this research include oat hull and corn stover. The biomass was injected into a fluidized sand bed reactor at approximately $500^{\circ} \mathrm{C}\left(932^{\circ} \mathrm{F}\right)$ with inert nitrogen as the fluidizing agent. The typical biomass feed rate was $7 \mathrm{~kg} / \mathrm{h}(15 \mathrm{lb} / \mathrm{h})$. This process typifies fast pyrolysis because of the high heating rates of the rather small particles of biomass (less than $1 \mathrm{~mm}$ or $0.003 \mathrm{ft}$ ). Once the biomass has been injected into the sand bed and pyrolyzes, the resulting gas stream exits the freeboard of the reactor and enters into two heated cyclones in series as labeled in Figure 3-9. The cyclones are enclosed in a heating jacket at $450^{\circ} \mathrm{C}\left(842^{\circ} \mathrm{F}\right)$, and therefore they are not in open view. This is the point in the flow in which the char is collected. A vast majority of the char (more than 95 percent) is collected by the first cyclone. Typical char yields at the prescribe temperature in the system are approximately 12 percent on a mass basis of biomass injected. At the end of the run, the char is removed from the cyclone collection bins, weighed, and sealed in containers. The remaining hot gas flow continues through a set of condensers and exits the system.

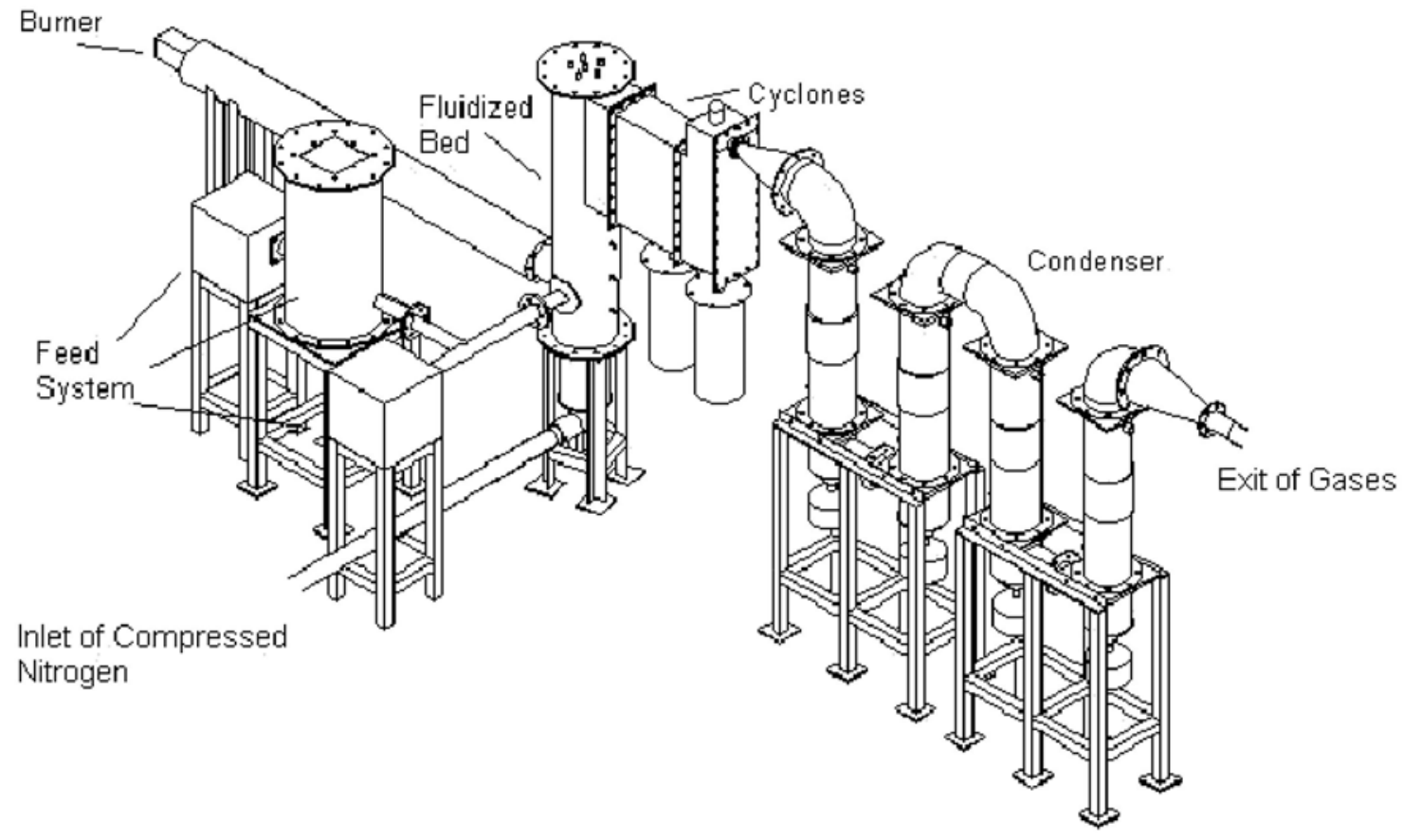

Figure 3-9. Schematic of Fast Pyrolysis Pilot Plant Used in the Production of Pyrolytic Chars from Oat Hulls and Corn Stover. 
Contents of carbon in chars obtained from oat hull and corn stover were measured with thermogravimetric analyses, which were performed with a programmable Perkin Elmer TGA-7. Char samples were heated in an oven prior to the TGA tests to remove moisture in the same manner as used in the LOI tests. The first step of a TGA test was to load $25 \pm 5 \mathrm{mg}(60 \pm 10 \mu \mathrm{lb})$ char sample into the TGA sample holder and then introduce nitrogen into the TGA furnace at a flow rate of $30 \mathrm{ml} / \mathrm{min}\left(0.001 \mathrm{ft}^{3} / \mathrm{min}\right)$ for approximately a half hour to purge the oxygen in the environment of the furnace. The loaded sample was then heated in the nitrogen atmosphere after the TGA apparatus was stabilized. The sample was first heated from room temperature to $750^{\circ} \mathrm{C}\left(1,382^{\circ} \mathrm{F}\right)$ at a heating rate of $20^{\circ} \mathrm{C} / \mathrm{min}\left(68^{\circ} \mathrm{F} / \mathrm{min}\right)$ the nitrogen environment to drive off volatile materials, including water from dehydration, carbon dioxide from calcinations of calcium carbonate and low molecular-weight hydrocarbons. Once $750^{\circ} \mathrm{C}\left(1,382^{\circ} \mathrm{F}\right)$ was reached, the temperature was held constant until the TGA curve became flat so that the volatile materials were completely released. Finally, nitrogen flow was stopped and the same flow rate $\left(30 \mathrm{ml} / \mathrm{min}\right.$ or $\left.0.001 \mathrm{ft}^{3} / \mathrm{min}\right)$ of air was admitted. The oxygen in the introduced air was used to oxidize carbon in char into carbon dioxide. The whole TGA test was completed when the height of the weight loss curve stopped changing.

Concentrations of other elements in chars, including $\mathrm{Na}, \mathrm{Mg}, \mathrm{Al}, \mathrm{Si}, \mathrm{P}, \mathrm{S}, \mathrm{K}, \mathrm{Ca}$, $\mathrm{Mn}, \mathrm{F}$, and Zn, were also evaluated using a Philips PW 2404 X-ray fluorescence spectrometer ( $\mathrm{Rh} \mathrm{X}$-ray tube operated at 3,600 watts). Several steps need to be taken to conduct these tests. First, char samples were homogenized by mixing in a Spex Mixer/Grinder for 5 minutes. Then, samples were also diluted 1:1 with lithium tetraborate. Standards were made by mixing NIST or Reagent grade standards with graphite or lithium tetraborate.

Mixtures were again homogenized by mixing in a Spex mixer/grinder for 5 more minutes. Specimens were presented to the spectrometer as loose powders. The powders were contained in disposable sample cups covered with polypropylene film. Scans were

made using both the raw samples and the samples that had been diluted. All scans were performed in a Helium atmosphere. The measured intensities were converted to concentration using the Philips IQ+ program (a fundamental parameters package). The measured intensity of one of the standards (Std 1) was used to check the procedure. Agreement was reasonable for all elements except for Iron $(\mathrm{Fe})$.

\subsubsection{Preparation and characterization of activated carbon}

One hundred grams of either oat hull char or corn stover char were placed in a porcelain evaporating dish and heated to $800^{\circ} \mathrm{C}$ in a Lindberg box furnace equipped with a gas-tight retort (Lindberg/Blue M, Watertown, WI). The char was heated in an inert 
atmosphere of nitrogen gas supplied to the retort at a flow rate of $0.1 \mathrm{~m}^{3} / \mathrm{hr}\left(3.5 \mathrm{ft}^{3} / \mathrm{hr}\right)$. Once the furnace temperature reached $800^{\circ} \mathrm{C}\left(1,472^{\circ} \mathrm{F}\right)$, water was pumped into the nitrogen gas stream at a rate of $3 \mathrm{~mL} / \mathrm{min}\left(0.0001 \mathrm{ft}^{3} / \mathrm{min}\right)$ in order to achieve steam activation. The chars were steam activated for 30, 60, 90, and $120 \mathrm{~min}$. At the conclusion of these time periods, the water flow was stopped and the heat source shut down. The chars were allowed to cool in the furnace overnight under an atmosphere of nitrogen gas.

The activated carbons were weighed to determine activation burn-off or mass loss due to activation. The following relationship was used:

Activation burn-off $($ percent $)=100-\{[$ mass after activation $(\mathrm{g}) /$ original mass $(\mathrm{g})] \times 100\}$

The activated carbons were washed with $0.1 \mathrm{M} \mathrm{HCl}$ to remove ash and then washed with water to remove residual acid. In each case, the carbon particles were retained on a 325 mesh sieve. The samples were then dried at $102^{\circ} \mathrm{C}\left(216^{\circ} \mathrm{F}\right)$. A final product yield or loss due to washing was recorded.

Surface area and pore size distribution of the carbons was determined by nitrogen adsorption at $77^{\circ} \mathrm{K}\left(-321^{\circ} \mathrm{F}\right)$ using a Micromeritics Gemini 2375 surface area analyzer (Micromeritics Inc., Norcross, GA) and a 15-points BET analysis. Micropore surface area and external surface area (mesopore + macropore surface area) were calculated by use of a t-plot.

\subsubsection{Results: concentrations of elements in chars}

TGA tests show that the carbon contents in oat hull char and corn stover char are 72.3 weight-percent and 68.0 weight-percent, respectively.

The results of other elements measured with Philips PW 2404 X-ray fluorescence spectrometer are listed in Table 3-7. 


\section{Table 3-7. Concentrations of Several Elements (as Oxide Forms) in Oat Hull Char and Corn Stover Char.}

\begin{tabular}{|c|c|c|}
\hline \hline Elements (as oxides) & $\begin{array}{c}\text { Oat Hull } \\
\text { (weight-percent) }\end{array}$ & $\begin{array}{c}\text { Corn Stover } \\
\text { (weight-percent) }\end{array}$ \\
\hline $\mathrm{Na}_{2} \mathrm{O}$ & 0.22 & $<0.02$ \\
\hline $\mathrm{MgO}$ & 1.11 & 0.17 \\
\hline $\mathrm{Al}_{2} \mathrm{O}_{3}$ & 0.06 & 0.06 \\
\hline $\mathrm{SiO}_{2}$ & 1.50 & 0.89 \\
\hline $\mathrm{P}_{2} \mathrm{O}_{5}$ & 1.55 & 0.07 \\
\hline $\mathrm{SO}_{3}$ & 0.44 & 0.06 \\
\hline $\mathrm{K}_{2} \mathrm{O}$ & 2.54 & 1.79 \\
\hline $\mathrm{CaO}$ & 0.33 & 1.67 \\
\hline $\mathrm{Mn}_{2} \mathrm{O}_{3}$ & $<0.02$ & 0.13 \\
\hline $\mathrm{Fe}_{2} \mathrm{O}_{3}$ & 0.47 & 0.17 \\
\hline $\mathrm{ZnO}$ & 0.1 & $<0.02$ \\
\hline
\end{tabular}

\subsubsection{Results: characterization of activated carbon}

The characterization results of activated carbon obtained from oat hull and corn stover are shown in Table 3-8 and Table 3-9, respectively.

Both activation burn-off and BET surface area appear to exhibit a linear relationship with respect to activation time of oat hulls (Table 3-8). Activated carbons with good surface area $\left(>500 \mathrm{~m}^{2} / \mathrm{g}\right.$ or $\left.2.4 \mathrm{Mft}^{2} / \mathrm{lb}\right)$ can be obtained with steam activation times of 90 min or longer. Total yields of activated carbon from the original mass of oat hulls need to be calculated from the char yield and the activation burn-offs.

Table 3-9 shows that for corn stover activated carbons, there is no linear relationship between activation time and BET surface area. However, activation burn-off and activation time appear to relate in a linear manner. BET surface area reaches a maximum at an activation time of $60 \mathrm{~min}$, and then declines at higher activation times. This may be due to the fragile structure of the corn stover char. As more surface area is generated there is a breakdown of the char particles. This explanation would explain the high mass loss due to washing at activation times of 90 and $120 \mathrm{~min}$ and the decline in BET surface area at those activation times. Corn stover is not likely to be a good candidate for activated carbon production. On the other hand, oat hulls seem to be a good source material for activated carbon production. 
Table 3-8. Activation Burn-Off, Loss Due to Washing, BET Surface Area and Pore Size Distribution of Oat Hull Activated Carbons.

\begin{tabular}{|c|c|c|c|c|}
\hline \hline $\begin{array}{c}\text { Activation } \\
\text { Time } \\
\text { (minute) }\end{array}$ & $\begin{array}{c}\text { Activation } \\
\text { Burn-Off } \\
\text { (percent) }\end{array}$ & $\begin{array}{c}\text { Mass Loss Due } \\
\text { to Washing } \\
\text { (percent) }\end{array}$ & $\begin{array}{c}\text { BET Surface } \\
\text { Area } \\
\left.\text { ( } \mathbf{m}^{\mathbf{2}} / \mathbf{g}\right)\end{array}$ & $\begin{array}{c}\text { Percent Micropores; } \\
\text { Percent (Meso + } \\
\text { Macropores) }\end{array}$ \\
\hline 0 (char) & none & none & 4.8 & 100 \\
30 & 20.8 & 9.2 & 349 & $91.4 ; 8.6$ \\
60 & 27.6 & 13.4 & 431 & $88.4 ; 11.6$ \\
90 & 33.5 & 10.5 & 522 & $86.8 ; 13.2$ \\
120 & 39.7 & 16.0 & 625 & $84.2 ; 15.8$ \\
\hline
\end{tabular}

Table 3-9. Activation Burn-Off, Loss Due to Washing, BET Surface Area and Pore Size Distribution of Corn Stover Activated Carbons.

\begin{tabular}{|c|c|c|c|c|}
\hline $\begin{array}{c}\text { Activation } \\
\text { Time } \\
\text { (minute) }\end{array}$ & $\begin{array}{c}\text { Activation } \\
\text { Burn-Off } \\
\text { (percent) }\end{array}$ & $\begin{array}{c}\text { Mass Loss Due } \\
\text { to Washing } \\
\text { (percent) }\end{array}$ & $\begin{array}{c}\text { BET Surface } \\
\text { Area } \\
\left(\mathbf{m}^{2} / \mathbf{g}\right)\end{array}$ & $\begin{array}{c}\text { Percent Micropores; } \\
\text { Percent (Meso + } \\
\text { Macropores) }\end{array}$ \\
\hline 0 (char) & none & none & 5.8 & 100 \\
30 & 26.2 & 18.7 & 424 & $88.7 ; 11.3$ \\
60 & 30.5 & 22.0 & 442 & $86.2 ; 13.8$ \\
90 & 37.5 & 28.8 & 374 & $85.0 ; 15.0$ \\
120 & 40.2 & 27.1 & 311 & $84.2 ; 15.8$ \\
\hline
\end{tabular}

\subsubsection{Recovery of Organic Compounds from Bio-oil}

The bio-oil contains a wide variety of organic compounds, as illustrated in Table 3-10 for corn stover. These include alcohols, aldehydes, carboxylic acids, ketones, saccharides, anhydrosugars, furans, and pyrolytic lignin. Of particular interest is the anhydrosugars, as detailed below. 
Table 3-10. Yields of Organic Compounds in Pyrolysis Syrups for Pretreatments of Corn Stover.

\begin{tabular}{|l|c|c|c|c|}
\hline \hline $\begin{array}{l}\text { Organics } \\
\text { (Weight Percent) }\end{array}$ & $\begin{array}{c}\text { No } \\
\text { Pretreatment }\end{array}$ & $\begin{array}{c}\text { Acid } \\
\text { Hydrolysis }\end{array}$ & $\begin{array}{c}\text { Demineraliza- } \\
\text { tion }\end{array}$ & $\begin{array}{c}\text { Demineralization } \\
\text { with catalyst }\end{array}$ \\
\hline Cellobiosan & Trace & 4.97 & 4.55 & 3.34 \\
\hline Levoglucosan & 2.75 & 23.10 & 17.69 & 20.12 \\
\hline $\begin{array}{l}\text { Hydroxy- } \\
\text { acetaldehyde }\end{array}$ & 11.57 & 3.93 & 5.97 & 3.73 \\
\hline Formic acid & 2.61 & 0.73 & trace & Trace \\
\hline Acetic acid & 3.40 & 0.40 & 1.51 & 1.26 \\
\hline Acetol & 4.53 & trace & trace & Trace \\
\hline Formaldehyde & 2.75 & 0.70 & 1.63 & Trace \\
\hline Pyrolytic lignin & 33.40 & 20.08 & 16.89 & 17.74 \\
\hline
\end{tabular}

Among the various components in bio-oil (or $\mathrm{BCO}$ ) those with a reasonable vapor pressure include:

- Low molecular weight carbonyl compounds

- Water

- Monomeric sugars

- Monomeric phenols

Other components are high molecular weight oligomeric phenolic fragments ("pyrolytic lignin") and oligomeric sugars and their partial decomposition products. Some researchers believe that this oligomeric material is not formed by vaporization but rather by direct ejection into the gas phase as aerosol particles and that this is partially why BCO shows irreversibility of distillation.

The volatility characteristics of the lower boiling components may be inferred from their known or estimated boiling points.

\subsubsection{Monomeric phenols}

Monomeric phenols (excluding phenol itself) derived from lignin include compounds with one or two methoxy groups ortho to the phenol group together with side chains of from $0-3$ carbons, para to the phenol group. Their molecular weights range from 124 (guaiacol) up to about 210 (sinapyl alcohol). Boiling points are given in Table 3-11. 
Table 3-11. Boiling Points of Some Monomeric Lignin-Related Phenols.

\begin{tabular}{|c|c|c|}
\hline $\begin{array}{l}\text { Monomeric Lignin-Related } \\
\text { Phenols }\end{array}$ & $\begin{array}{l}\text { Experimental } \\
{ }^{\circ} \mathrm{C}\left({ }^{\circ} \mathrm{F}\right)\end{array}$ & $\begin{array}{c}\text { Estimated" } \\
{ }^{\circ} \mathrm{C}\left({ }^{\circ} \mathrm{F}\right)\end{array}$ \\
\hline Phenol & $182(360)$ & - \\
\hline Guaiacol & $205(401)$ & $211(412)$ \\
\hline Methyl Guaiacol & - & $230(446)$ \\
\hline Vinyl Guaiacol & - & $247(477)$ \\
\hline Syringol & - & $249(480)$ \\
\hline Eugenol & $254(489)$ & - \\
\hline IsoEugenol & - & $270(518)$ \\
\hline Vanillin & $\begin{array}{c}170 @ 15 \mathrm{mmHg} \\
(338 @ 0.3 \mathrm{psi})\end{array}$ & $274(525)$ \\
\hline AcetoGuaiacone & - & $281(538)$ \\
\hline Syringaldehyde & $\begin{array}{c}193 @ 14 \mathrm{mmHg} \\
(379 @ 0.3 \mathrm{psi})\end{array}$ & $305(581)$ \\
\hline Coniferyl Alcohol & $\begin{array}{l}164 @ 3 \mathrm{mmHg} \\
(327 @ 0.06 \mathrm{psi})\end{array}$ & $325(617)$ \\
\hline Sinapyl Alcohol & - & $350(662)$ \\
\hline Ferulic Acid & - & $354(669)$ \\
\hline
\end{tabular}

Note that the yields of individual compounds are small (0.5 - 2 percent each) and it would perhaps be simplest to collect impure fractions and to vacuum distil if higher purity was required.

Some of these phenols are quite valuable, $\sim$ tens of dollars $/ \mathrm{kg}$, as flavors or flavor/pharmaceutical precursors and other specialty chemicals. For example, ferulic acid, coniferyl alcohol, 4-vinyl guaiacol and eugenol can all be fermented to valuable natural vanillin. On the other hand, phenol itself sells at about $\$ 1 / \mathrm{kg}(\$ 0.5 / \mathrm{lb})$. Given the present interest in BCO derived ("green") resin formulations, it seems likely that impure mixtures of monomeric phenols could command something in this price range.

\subsubsection{Levoglucosan}

Levoglucosan is an anhydrosugar with only limited commercial production at present but having broad potential as a platform molecule for green chemistry. A recent review by Radlein (2000) suggests its use in applications ranging from production of fermentation products (lactic acid, citric acid, etc.) to pharmaceuticals. However, 
levoglucosan has been little studied for commercial applications because technical grade levoglucosan costs as much as $\$ 50 / \mathrm{g}(\$ 22,680 / \mathrm{lb})$. Pyrolysis of raw biomass typically yields only a few percent levoglucosan. However, studies by several researchers reveal that pyrolytic yields can be dramatically increased to as much as 30 percent by pretreating biomass to remove alkaline compounds (primarily potassium). Pretreatment is very simple, consisting of washing the biomass in weak acid to remove water-soluble alkali (this pretreatment also mitigates the previously described problem of alkali corrosion and erosion in gas turbines).

The principal monomeric anhydrosugar is levoglucosan (1,6 anhydro- $\beta-\mathrm{D}-$ glucose). Its yield is generally in the range 3 - 10 weight percent for untreated biomass and up to 17 percent for demineralized biomass. E. Suuberg et al (1996) has measured the vapor pressure of levoglucosan as:

$$
\text { In } \mathrm{P} \text { [torr }]=32.391-14452 / \mathrm{T}[\mathrm{K}]
$$

indicating a boiling point of about $288^{\circ} \mathrm{C}\left(550^{\circ} \mathrm{F}\right)$. (Compare glycerol which also has three hydroxyl groups and which boils - with decomposition - at $290^{\circ} \mathrm{C}$ or $554^{\circ} \mathrm{F}$.) The estimate therefore seems reasonable - especially in view of the fact that the hydroxyl groups of levoglucosan are rigidly held and presumably therefore less able to form strong intermolecular hydrogen bonds that decrease volatility. For comparison, the Stein and Brown method (Stein and Brown, 1994) gives a boiling point of $314^{\circ} \mathrm{C}\left(597^{\circ} \mathrm{F}\right)$. For the purposes of separation, it should also be noted that levoglucosan and other oligomeric sugars are water-soluble while most of the pyrolytic lignin is not.

\subsubsection{3 $C_{1}-C_{3}$ carbonyl compounds}

The predominant low molecular weight carbonyls include formaldehyde, glycolaldehyde, glyoxal, acetol and acetic acid. The aldehydes are characterized by a high affinity for water with the formation of hydrates of much reduced volatility. (This fact is also a contributor to the irreversibility in the distillation of BCO.) Examples of boiling points are given in Table 3-12.

The aldehydes are also very reactive. For example, anhydrous formaldehyde is a gas at room temperature but in the presence of liquid water it will exist mainly in solution as a hydrate even at elevated temperatures. 
Table 3-12. Boiling Points of Some Low Molecular Weight Carbonyls.

\begin{tabular}{|c|c|c|}
\hline $\begin{array}{l}\text { Low Molecular Weight } \\
\text { Carbonyls }\end{array}$ & $\begin{array}{l}\text { Experimental } \\
\quad{ }^{\circ} \mathrm{C}\left({ }^{\circ} \mathrm{F}\right) \\
\end{array}$ & $\begin{array}{c}\text { Estimated } \\
{ }^{\circ} \mathrm{C}\left({ }^{\circ} \mathrm{F}\right)\end{array}$ \\
\hline Formaldehyde & $-19.5(-3)$ & - \\
\hline $\begin{array}{l}\text { Methylene Glycol } \\
\text { (Formaldehyde Hydrate) }\end{array}$ & $145^{* *}(293)$ & $131(268)$ \\
\hline Glycolaldehyde & - & $126(259)$ \\
\hline Glycolaldehyde Hydrate & - & $205(401)$ \\
\hline Acetic Acid & $118(244)$ & - \\
\hline Acetol & $146(295)$ & - \\
\hline Glyoxal & $51(124)$ & - \\
\hline Glyoxal Dihydrate & - & $252(486)$ \\
\hline
\end{tabular}

It is therefore exceedingly difficult to predict the likely boiling points of condensates from this fraction. The kinetics of the various reactions that they can undergo will play a major role. Nevertheless, collectively these constitute the lowest boiling fraction in the bio-oil.

For untreated biomass feedstocks the total amount of these compounds is of the order of 10 - 20 weight percent of the bio-oil and they arise mainly from the thermal decomposition of the holocellulose fraction. On the other hand, the available data suggest that if the feedstock is demineralized to enhance levoglucosan yields, their total amount falls significantly to only a few percent. The decision as to whether to attempt to recover a low molecular carbonyls fraction would be determined by its economic value.

\subsubsection{Utilization of Levoglucosan}

\subsubsection{Ethanol production}

Radlein (2000) has discussed applications of levoglucosan as a fermentation feedstock recently in some detail. It was pointed out that naturally occurring microorganisms have been discovered that can utilize levoglucosan as a substrate. For example, Kitamura et al (1991) have studied the metabolism of levoglucosan. They refer to prior work indicating that many yeasts and fungi can use it as a carbon source and suggest that for eucaryotic microorganisms (i.e. yeasts and fungi) capable of utilizing 
levoglucosan, the first step involves phosphorylation to glucose-6-phosphate. The responsible enzyme, termed "levoglucosan kinase" was isolated. In earlier work they also showed that Aspergillus terreus converts levoglucosan to itaconic acid with the same yield and rate as in the conversion of glucose. Subsequently (Nakahara et al, 1994) a new organism, Arthrobacter sp., isolated from soil was found to hydrolyze levoglucosan to glucose by a novel enzyme, levoglucosan dehydrogenase. Thus, somewhat surprisingly perhaps, levoglucosan specific enzymes do occur in nature; a fact that should no doubt have a strong bearing on the feasibility of genetic modification of organisms for levoglucosan specific activity.

Indeed an old German patent (Schuchardt, 1943) suggests that levoglucosan or wood carbonization liquors containing it can be used as a nutrient in the production of yeast, e.g. torula utilis. Blazej and Kosik (1993) reported that aureobasidium pollulans CCI-2771-14 showed good growth rates using anhydrosugars as a single carbon source on which basis they suggested that direct conversion of anhydrosugars to fodder yeast has great potential.

Prosen et al, (1993) have also identified several yeast species that grow on, albeit slowly, and produce ethanol from aqueous pyrolysates extract containing levoglucosan and other anhydrosugars.

Thus the available information is that there exist microorganisms that convert levoglucosan and other anhydrosugars directly to various products. However ethanol production seems to be the only existing large scale fermentative application that offers immediate markets. Unfortunately direct fermentation of anhydrosugars to ethanol is slow. No doubt specific development of organisms for this purpose would give dramatic improvements. Nevertheless it is clear that at the present state of the art, the anhydrosugars must first he hydrolysed to free sugars then fermented. It is therefore imperative that a cheap and efficient hydrolysis method be available.

The most obvious approach is acid hydrolysis that is well known to convert anhydrosugars to free sugars. The kinetics have been studied by Ménard et al (1984). Using $\sim 3 \mathrm{~N} \mathrm{H}_{2} \mathrm{SO}_{4}$, hydrolysis of pure levoglucosan was essentially complete in less than 30 minutes at $100^{\circ} \mathrm{C}\left(212^{\circ} \mathrm{F}\right)$. At the same temperature, complete conversion required about 3 hour. using $0.3 \mathrm{~N}$ acid.

Katritzky et al (1996) have described an even cheaper and simpler method that requires no acid. They report that a 0.30 Molar aqueous solution of LG was quantitatively converted to predominantly glucose and traces of another glucose isomer at $205^{\circ} \mathrm{C}\left(401^{\circ} \mathrm{F}\right)$. This result is probably because liquid water intrinsically becomes both more acidic and more basic at elevated temperatures so besides the normal thermal acceleration there is an enhanced catalytic effect. At $205^{\circ} \mathrm{C}\left(401^{\circ} \mathrm{F}\right)$, the vapor pressure 
of pure water is $1,906 \mathrm{kPa}$ (276 psi) so the required conditions are relatively mild and thus, such a process step would be expected to be rather inexpensive. Unfortunately, kinetic data, which is required for equipment sizing, were not given so a precise cost estimate cannot be made. Nevertheless, it requires only the single extra unit operation of pumping an aqueous solution through a pressurized and heated tube.

\subsubsection{Higher value uses}

Although production of fermentable sugars is the most immediate application, there are other potential higher value uses for levoglucosan. These have also been discussed by Radlein (2000). We are interested here in possible large-scale usage so that it might be compatible with the scale of energy production. In the author's view, the only presently viable potential candidate is the production of biodegradable and "renewable" alkyl glycoside surfactants. These are premium products that find current application in soaps and cosmetics. They are presently made by condensation reactions of sugars with vegetable oil derived alcohols or acids.

A major issue with the current method is that the reactions are generally nonselective so that purification of the product is a difficult and expensive operation. On the other hand, preliminary experiments have indicated that levoglucosan can be combined by direct addition reaction with alkanols under non-aqueous conditions to give alkyl glucosides in almost stoichiometric yield (D. Radlein, unpublished data), as shown in Figure 3-10.

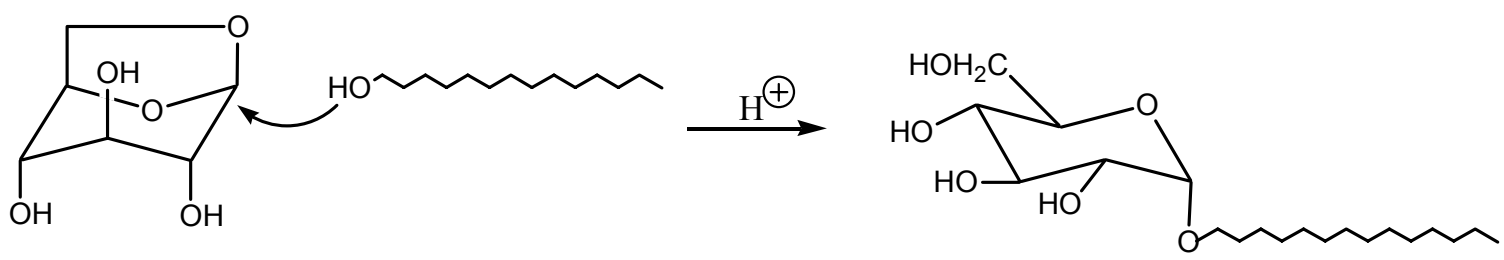

Figure 3-10. Addition Reaction of Levoglucosan with an Alkanol to give an Alkyl Glucoside.

Such an application would require pure levoglucosan. It is difficult to estimate a value for such an application. However, given that prices of alkyl glucosides appear to be in the range $\$ 1,500-2000 /$ ton, and considering that pure sugars costing $>\$ 1 / \mathrm{kg}$ $(\$ 0.5 / \mathrm{lb})$ are the normal starting materials for alkyl glycoside synthesis, while considering the advantages that a method giving a pure product might provide, it seems reasonable to 
estimate that such an application could generate a price of at least $\$ 1-2 / \mathrm{kg}(\$ 0.5-1 / \mathrm{lb})$ for pure levoglucosan. The degree of product purity required would be higher though.

\subsubsection{Economics of Levoglucosan Recovery from Bio-oil Production}

Although activated carbon and several organic compounds are potential coproducts from the production of bio-oil, only the economics of recovering levoglucosan are reviewed here. Although economically attractive, entry into the activated carbon market is purportedly very difficult to achieve. Levoglucosan, among the organic compounds in bio-oil, occurs in the highest yield (when the raw biomass is demineralized) and has the most potential as a platform chemical for high-value product development.

No commercially available system for obtaining anhydrosugar from bio-oil is available at this time. Standard cost-estimating methods were used to estimate the cost of such a system. The system consists of two subsystems: a pretreatment system to demineralize the raw biomass and a fractionating quencher described in the previous section.

The pretreatment system, illustrated in Figure 3-11, consists of: a hammermill to reduce biomass to fibers of lengths of $1-3 \mathrm{~mm}(0.003-0.01 \mathrm{ft})$; a washing unit to remove alkali from the biomass; a press to remove wash water from the biomass; and a dryer to bring moisture to $10-20$ percent. The hammermill and press were designed to process $5,390 \mathrm{~kg} / \mathrm{h}(11,883 \mathrm{lb} / \mathrm{h})$ of biomass. The washing unit was sized to $10.6 \mathrm{~m}^{3}$ $\left(373 \mathrm{ft}^{3}\right)$, which provides a residence time of 15 minutes for biomass with a bulk density of $130 \mathrm{~kg} / \mathrm{m}^{3}\left(8.1 \mathrm{lb} / \mathrm{ft}^{3}\right)$. The dryer was designed to give about $100 \mathrm{~s}$ residence time to the biomass and is estimated to require $2.0 \mathrm{~m}^{2}$ of cross-sectional area.

The estimated f.o.b. costs for these various components and the assumptions made in deriving these estimates are detailed in Table 3-13. Bare-module costs for installed equipment, also given in Table 3-13, were calculated according to the methodology of Table 3-4. The total cost of the pretreatment system is estimated to be $\$ 0.72$ million.

The major operating cost for the pretreatment system is acid to demineralize the biomass. Very little data is available on the optimum amount of acid for this purpose. Based on data on the use of steep water in the wet corn milling industry, it was assumed that $0.75 \mathrm{~kg}(1.6 \mathrm{lb})$ of acid solution (20 weight-percent nitric acid) was required for every kilogram of biomass. This equates to 29 million $\mathrm{kg} / \mathrm{yr}$ of acid. At $\$ 77 / \mathrm{Mg}$, the annual cost of acid is $\$ 2.3$ million. 
Biomass

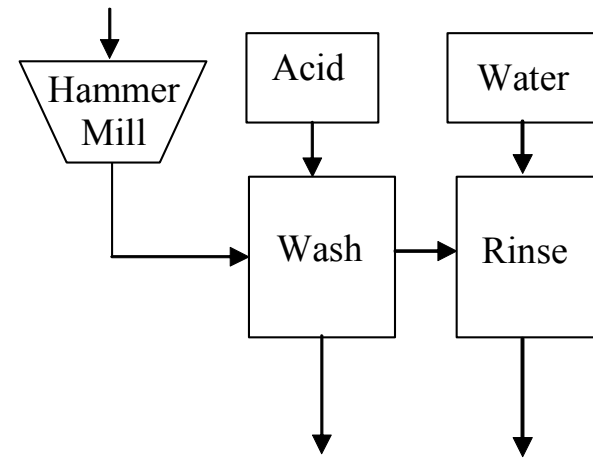

Discharge

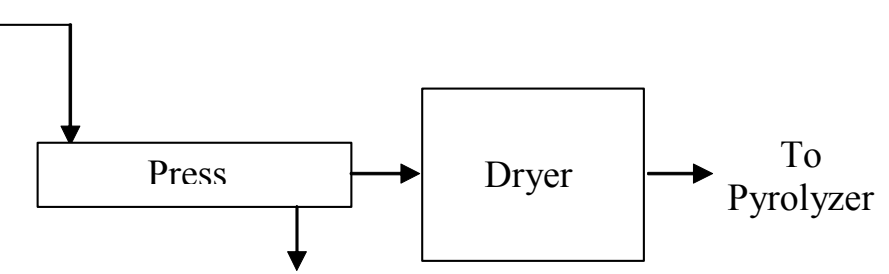

Discharge

Figure 3-11. Biomass Washing and Drying System for Demineralizing Biomass.

Table 3-13. Cost Estimate for Biomass Pretreatment System.

\begin{tabular}{|c|c|c|c|}
\hline Component & Cost f.o.b. & Scaling Relationship" & Bare Module Cost \\
\hline Hammermill & $\$ 11,720$ & $\$ 2,800$ (ton per hour) $)^{0.85}$ & $\$ 33,510$ \\
\hline Wash vessel & $\$ 25,560$ & $\$ 6,200\left(\mathrm{~m}^{3}\right)^{0.6}$ & $\$ 92,640$ \\
\hline Press & $\$ 224,000$ & Ulrich, 1984 & $\$ 542,000$ \\
\hline Dryer & $\$ 21,400$ & $\$ 16,000\left(\mathrm{~m}^{3}\right)^{0.42}$ & $\$ 59,100$ \\
\hline & & TOTAL & $\$ 727,250$ \\
\hline
\end{tabular}

A cost estimate was also prepared for the fractionating quencher and related separation equipment to extract levoglucosan from bio-oil. The proposed design is shown in Figure 3-8. The following major components are included in the design:

- Fractionating Column

- Heat Exchanger (Condenser)

- Separator Drum

- Hydrolyser

- Sugar Solution Storage Tank

- Pumps 
The capital cost estimating approach for the fractionating condenser is detailed in Appendix A. The estimated capital cost is $\$ 545,480$. Operating costs for chemical recovery were estimated at $\$ 1.0$ million.

Table 3-14 summarizes the capital costs and operating costs estimated for the recovery of anhydrosugar from pyrolyzed biomass. The market price for levoglucosan is difficult to estimate because it is not currently produced in commercial quantities. However, other sugar derivatives, such as sorbitol, sell for as much as $\$ 1 / \mathrm{kg}(\$ 0.5 / \mathrm{lb})$. With an annual production of $5.8 \times 10^{6} \mathrm{~kg} / \mathrm{y}\left(12.8 \times 10^{6} \mathrm{lb} / \mathrm{y}\right)$, this represents annual revenue of $\$ 5.8$ million.

Table 3-14. Summary of Capital Costs and Operating Costs for Recovering Levoglucosan from Pyrolyzed Biomass.

\begin{tabular}{|l|c|c|}
\hline \hline Subsystem & $\begin{array}{c}\text { Capital Cost } \\
\text { (million) }\end{array}$ & $\begin{array}{c}\text { Annual Operating Cost } \\
\text { (million) }\end{array}$ \\
\hline Pretreatment & $\$ 0.73$ & $\$ 2.3$ \\
\hline Anhydrosugar separation & $\$ 0.55$ & $\$ 1.0$ \\
\hline TOTAL & $\$ 1.27$ & $\$ 3.3$ \\
\hline
\end{tabular}

\subsubsection{Comparative Economics of Levoglucosan for Ethanol Production}

In order to evaluate the economics of utilization of levoglucosan as a source for ethanol, the manner in which it could potentially integrate into the existing infrastructure must be examined.

Current large-scale (fuel) ethanol production in North America is largely from corn. Dry corn typically contains about 61 percent of starch that can be converted to fermentable sugars. Generally the corn is ground by either wet-milling or dry-milling following which the starch is hydrolysed in a first stage that reduces the starch to oligomeric fragments and in a second stage that converts the oligomers to free monomolecular sugars. Both acidic as well as enzymatic hydrolyses are used for these purposes. The solution of free sugars is then fermented to ethanol. In present practice, the overall efficiency of conversion of starch to ethanol is very high - well over 90 percent of the theoretical yield is attainable. Indeed while typical yields are around 9.5 L ethanol/bushel of corn (2.5 gal/bushel of corn), as high as $11 \mathrm{~L} / \mathrm{bushel}$ of corn ( $2.8 \mathrm{gal} / \mathrm{bushel}$ ) have been achieved with recent technology.

Since the fermentable sugar solution is not normally separated out as a final product, it is difficult to estimate a precise cost for it, without a detailed process analysis. However, data in Table 3-15, obtained from Program Evaluation Division, Office of the 
Legislative Auditor, Minnesota State Government: (http://www.auditor.leg.state.mn.us/ ped/pedrep/9704toc.html), may provide some guidance.

\begin{tabular}{|l|c|}
\hline \multicolumn{2}{|c|}{ Table 3-15. Costs of Dry Milling Corn in Minnesota } \\
\hline & \$/L of Ethanol (\$/gal) \\
\hline Costs & $0.23(0.88)$ \\
Corn (1988 - 95 average) & $0.10(0.37)$ \\
Variable costs, except for corn & $\underline{0.08(0.29)}$ \\
Fixed costs & $0.41(1.54)$ \\
$\quad$ Total & $0.34(1.27)$ \\
Revenues & $0.11(0.42)$ \\
Ethanol (1988 - 95 average price) & $\underline{0.05(0.20)}$ \\
Average DDGS* revenue & $0.50(1.89)$ \\
Minnesota state subsidy & \\
\hline Total & \\
\hline Note: & DDGS = Distillers Dry Grain with Solubles (fermentation residue principally used \\
for animal feed). & \\
\hline
\end{tabular}

The current cost of corn is approximately $\$ 2 /$ dry bushel. Since the starch content of the corn is about 61 percent, the effective cost of starch for fermentation works out at $\$ 0.116 / \mathrm{kg}(\$ 0.005 / \mathrm{lb})$ starch. As mentioned above it is not so easy to separate out the cost of the two hydrolytic steps involved in the conversion of the starch to fermentable sugar solution, but it must be less than the total non-corn variable costs of $\$ 0.10 / \mathrm{L}$ of ethanol (\$0.37/gal) as shown in Table 3-15.

One gallon ethanol is equivalent to $6.2 \mathrm{~kg}$ starch at the conversion rate of 2.5 gal/bushel. Assuming hydrolysis to be a quarter of non-corn variable costs gives an estimate of only $\$ 0.012 / \mathrm{kg}$ starch. Thus we estimate the total production cost of fermentable sugar solution from corn at $\$ 0.128 / \mathrm{kg}$ of dry sugars. This is therefore the target price at which "thermo - saccharification" becomes competitive with cornstarch for ethanol production.

As a check against these numbers one may compare current prices for food grade glucose syrups and high fructose corn syrups (HFCS):

Glucose Syrup (19.7 percent moisture) $\quad \$ 0.352 / \mathrm{kg}$ dry sugars (Wholesale list price, MidWest markets)

HFCS -42 (29 percent moisture) $\quad \$ 0.286 / \mathrm{kg}$ dry sugars (MidWest spot price, July '02) 
They appear to be compatible with our estimate for cost estimate for fermentative sugars in solution in that they are more refined products.

In order to justify the production of such solutions from levoglucosan rich pyrolysates within the power production system under study, one must compare with the alternative product, namely electrical power. There is even more uncertainty here as electrical energy prices vary very considerably with location and season. However, as an example one might consider that residential the electrical price in Iowa was $\$ 0.081 / \mathrm{kWh}$ in 2001. (See: http://www.blueowltechnologies.com/pmcPricesUSA.asp)

A part of this price represents distribution and transmission charges. Assume that the actual energy commodity price is 60 percent of the total cost then we estimate the former at $\sim \$ 0.050 / \mathrm{kWh}$.

Now assume that the pyrolysis liquids have a heating value of $17 \mathrm{MJ} / \mathrm{kg}$ $(7,309 \mathrm{Btu} / \mathrm{lb})$ and that this is converted to electrical power at 30 percent efficiency. Then the value of the electrical energy product is about $\$ 71 /$ ton $(\$ 0.03 / 1 b)$ pyrolysis liquids. On the other hand, the value of that fraction of the pyrolysis liquids that can be converted to fermentable sugars is $\$ 128 /$ ton $(\$ 0.06 / \mathrm{lb})$ of the convertible fraction of pyrolysis liquid - approximately double the value per ton than power production.

More detailed comparison of the production of levogluasan versus the production of electrical power is provided in Section 5, Economic Analysis.

\subsection{Gas Turbine Cycle Design}

There are a variety of energy conversion options for the bio-oil produced by the pyrolysis process. These include boilers, internal combustion engines, combustion or "gas" turbines, and perhaps advanced devices including Stirling engines. Each of these devices has its own advantages and disadvantages. However, the low cost, high efficiency, established commercial maturity, and suitability for recovery of waste heat in a combined cycle makes combustion turbines the preferred alternative for this study.

This section provides an introduction to gas turbine technology, properties of biooil relevant to gas turbines, gas turbine options, and a description of the turbine proposed for this project, the Orenda Aerospace OGT2500.

\subsubsection{Introduction to Gas Turbine Technology}

The first successful gas turbine was completed in 1903. Over the next forty years, rapid advances were made to improve the technology to make it a viable means of aircraft propulsion. As the technology matured, gas turbines were adapted to land-based energy generation uses. With the deregulation of the power industry in the 1990s, gas 
turbines became the generator of choice for a vast majority of all new power projects. Gas turbines currently have lower capital costs, shorter construction durations and lower operation and maintenance costs than any other large central plant available on the market.

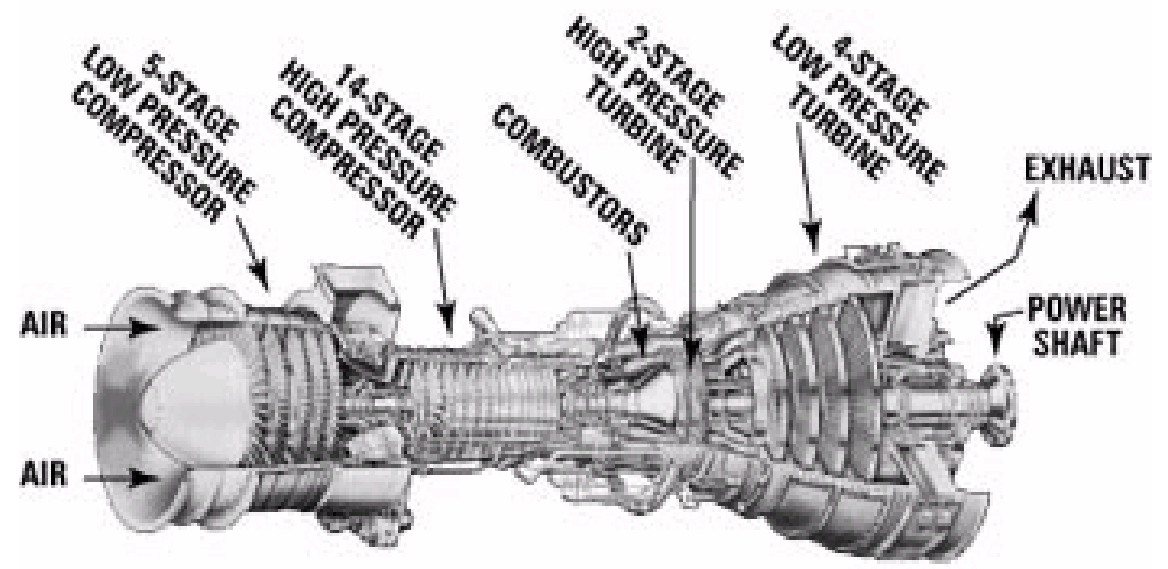

Figure 3-12. Gas Turbine Section (Source: Langston).

Power is generated when the combustion turbine compresses ambient air to approximately 12 to 16 atmospheres, heats the pressurized air to $1,100^{\circ} \mathrm{C}\left(2,000^{\circ} \mathrm{F}\right)$ or more by burning oil, natural gas or other fuels, and then expands those hot gases through a turbine. The turbine then drives both the air compressor and an electric generator. A typical combustion turbine would convert 30 to 35 percent of the fuel energy to electric power, with a substantial portion of the fuel energy exhausted in the form of hot gases exiting the turbine. When the combustion turbine is used to generate power and no energy is captured from the hot exhaust gasses, the power cycle is referred to as a "simple cycle" power plant.

Simple cycle combustion turbines are the power generation technology of choice for peaking service in the current domestic power industry. Simple cycle technology provides many of the same positive attributes as reciprocating engines, including rapid startup and modularity for ease of maintenance. In addition, combustion turbines have several advantages over reciprocating engines, including lower emissions and lower capital cost.

Simple cycle turbines can burn natural gas, diesel, propane, biogas and some bioderivative fuels such as bio-diesel and bio-oil. The next section describes some of the bio-oil properties relevant to gas turbines. 


\subsubsection{Bio-Oil Properties Relevant to Gas Turbine Engines}

As a clean fuel, bio-oil has a number of environmental advantages over fossil fuels:

- $\mathrm{CO} 2$ / Greenhouse Gas Neutral - because bio-oil is derived from biomass (organic waste), it is considered to be greenhouse gas neutral and can generate carbon dioxide credits.

- No SOx Emissions - As biomass does not contain sulfur, bio-oil produces virtually no SOx emissions and, therefore, would not be subjected to SOx taxes.

- Low NOx - Bio-oil fuels generate more than 50 percent lower NOx emissions than diesel oil in gas turbines.

- Renewable and Locally Produced - Bio-oil can be produced in countries where there are large volumes of organic waste.

As bio-oil has unique properties as a fuel, it requires special consideration and design modifications. Some of these properties are presented in Table 3-16 and are compared to those of diesel fuel.

Table 3-16. Typical Properties of Bio-Oil Compared to Diesel Fuel.

\begin{tabular}{|l|c|c|}
\hline \hline & Bio-Oil & Diesel \\
\hline Calorific Value MJ/kg & $15-20$ & 42.0 \\
\hline Kinematic Viscosity cSt & $3-9 @ 80^{\circ} \mathrm{C}$ & $2-4 @ 20^{\circ} \mathrm{C}$ \\
\hline Acidity $\mathrm{pH}$ & $2.3-3.3$ & 5 \\
\hline Water wt $\%$ & $20-25$ & \multirow{2}{*}{$0.05 \mathrm{v} \%$ (combined) } \\
\hline Solids wt $\%$ & $<0.1$ & 0.01 \\
\hline Ash wt $\%$ & $<0.02$ & $<1$ \\
\hline Alkali $(\mathrm{Na}+\mathrm{K}) \mathrm{ppm}$ & $5-100$ & \\
\hline
\end{tabular}

\subsubsection{Combustion Turbine Options}

A number of manufacturers offer combustion turbine systems in the size range appropriate for this study. Table 3-17 provides key characteristics for small combustion turbines. It must be noted that not all of these turbines are suitable for bio-oil use. The next section discusses criteria for selecting an appropriate combustion turbine. 
Table 3-17. Small Gas Turbine Characteristics.

\begin{tabular}{|c|c|c|c|c|c|c|}
\hline Manufacturer & CT Model & $\begin{array}{c}\text { Base Load Output } \\
\text { kW }\end{array}$ & $\begin{array}{c}\text { Heat Rate }^{2} \\
\text { Btu/kWh }\end{array}$ & $\begin{array}{c}\text { Efficiency }^{2} \\
\text { Percent }\end{array}$ & $\begin{array}{c}\text { Budget Price } \\
\text { USS }\end{array}$ & $\begin{array}{c}\text { Budget Price }^{1} \\
\text { US\$/kW }\end{array}$ \\
\hline Dresser-Rand & KG2-3E & 1,830 & 21,070 & 16 & $1,200,000$ & 656 \\
\hline Pratt \& Whitney & ST18A & 1,960 & 11,300 & 30 & $1,200,000$ & 612 \\
\hline Orenda Aerospace & OGT2500 & 2,730 & 12,515 & 27 & $1,435,000$ & 526 \\
\hline Mashproekt & UGT-2500 & 2,850 & 12,430 & 28 & $1,390,000$ & 488 \\
\hline Kawasaki Heavy Industries & M1T13D & 2,900 & 14,460 & 24 & $1,625,000$ & 560 \\
\hline Vericor Power Systems & VPS3 & 3,105 & 12,775 & 27 & $1,520,000$ & 490 \\
\hline Pratt \& Whitney & ST30 & 3,340 & 10,660 & 32 & $1,600,000$ & 479 \\
\hline Solar Turbine & Centaur 40 & 3,515 & 12,240 & 28 & $1,400,000$ & 398 \\
\hline Vericor Power Systems & VPS4 & 3,570 & 11,800 & 29 & $1,601,000$ & 448 \\
\hline Rolls-Royce & 501-KB5S & 3,950 & 11,765 & 29 & $1,600,000$ & 405 \\
\hline Iskra Energetika & GTES-4 & 4,100 & 14,130 & 24 & $1,230,000$ & 300 \\
\hline Pratt \& Whitney & ST40 & 4,040 & 10,310 & 33 & $1,800,000$ & 446 \\
\hline Solar Turbine & Centaur 50 & 4,600 & 11,630 & 29 & $1,600,000$ & 348 \\
\hline Iskra Energetika & GTES-5 & 5,200 & 13,050 & 26 & $1,534,000$ & 295 \\
\hline Solar Turbine & Taurus 60 & 5,200 & 11,225 & 30 & $1,800,000$ & 346 \\
\hline GE Oil \& Gas & PGT5 & 5,220 & 12,720 & 27 & $1,900,000$ & 364 \\
\hline Alstom Power & Typhoon 5.25 & 5,250 & 11,200 & 31 & $1,850,000$ & 352 \\
\hline Rolls-Royce & $501-\mathrm{KB} 7$ & 5,275 & 11,200 & 31 & $1,750,000$ & 332 \\
\hline Kawasaki Heavy Industries & M7A-01 & 5,840 & 11,230 & 30 & $2,310,000$ & 396 \\
\hline GE Oil \& Gas & PGT5B & 5,900 & 10,700 & 32 & $2,050,000$ & 347 \\
\hline Iskra Energetika & GTES-6 & 6,200 & 12,780 & 27 & $1,705,000$ & 275 \\
\hline Rolls-Royce & 501-KH5 (Steam Injection) & 6,420 & 8,560 & 40 & $2,300,000$ & 358 \\
\hline Rolls-Royce & $601-K B 9$ & 6,450 & 10,615 & 32 & $2,450,000$ & 380 \\
\hline
\end{tabular}

Source: Gas Turbine World 2001-2002 Handbook.

1. Budget prices in 2001US\$ for basic electric power generator packages including a single-fuel gas turbine, air cooled electric generator, skid and enclosure, inlet and exhaust ducts with silencers, standard control and starting systems, and conventional combustion system.

2. Based on ISO conditions of $15^{\circ} \mathrm{C}\left(59^{\circ} \mathrm{F}\right)$ at sea level site conditions and 60 percent relative humidity with zero inlet and zero outlet duct losses. 


\subsubsection{OGT2500 Combustion Turbine}

DynaMotive and Orenda Aerospace have cooperated on development of the 2.5 MW OGT2500 industrial gas turbine engine for applications with bio-oil. Based on promising results from testing completed so far, this turbine (see Figure 3-13) appears to be a viable candidate for bio-oil utilization. The project design includes two OGT2500 turbines. Table 3-18 shows the predicted OGT2500 performance on bio-oil.

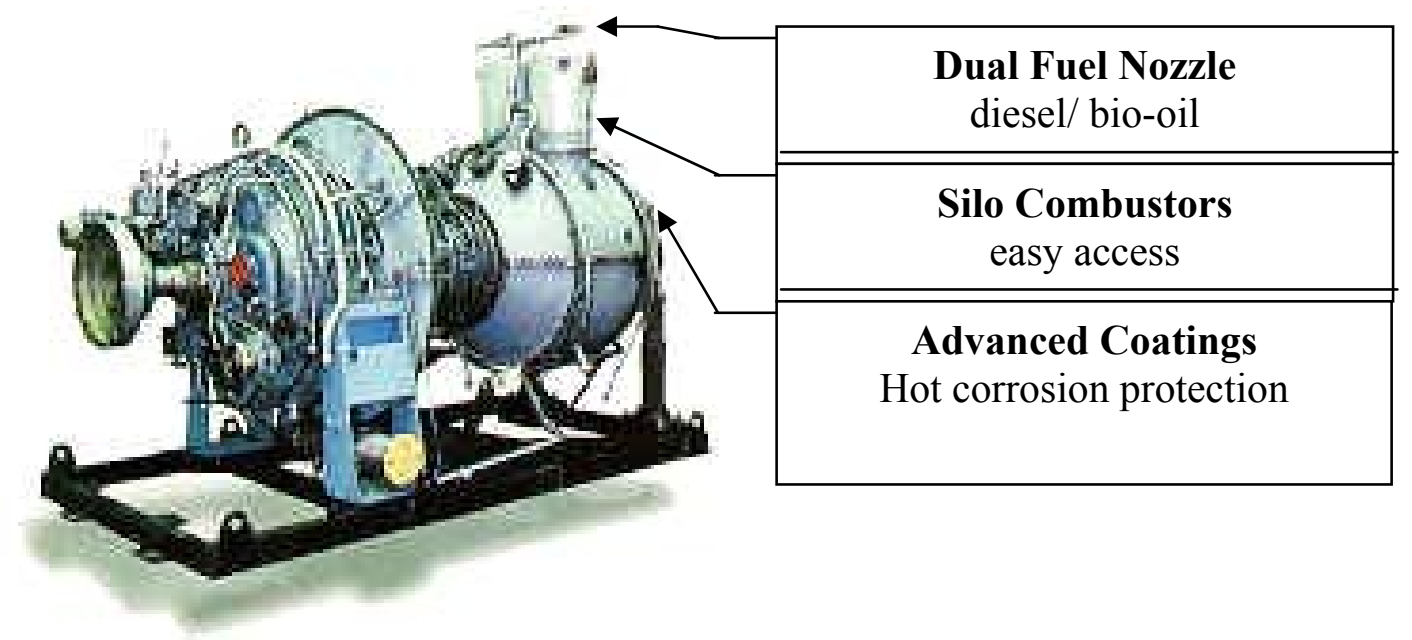

Figure 3-13. Application of Pyrolysis Oil to Gas Turbine Operation (OGT2500).

\begin{tabular}{|l|c|c|}
\hline \multicolumn{2}{|c|}{ Table 3-18. OGT2500 Predicted Performance on Bio-oil. } \\
\hline \hline & Metric Units & English Units \\
\hline Ambient Conditions & $101.4 \mathrm{kPa}$ & $14.7 \mathrm{psia}$ \\
Barometric Pressure & $15.0^{\circ} \mathrm{C}$ & $59^{\circ} \mathrm{F}$ \\
Dry Bulb Temperature & $60^{\circ} \%$ & $60^{\circ}$ \\
Relative Humidity & $10.81^{\circ} \mathrm{C}$ & $51.47^{\circ} \mathrm{F}$ \\
Wet Bulb Temperature & $0.63 \%$ & $0.63 \%$ \\
Humidity Ratio & & \\
Fuel Parameters & $2,073 \mathrm{kG} / \mathrm{hr}$ & $4,569 \mathrm{lb} / \mathrm{hr}$ \\
Fuel Flow & $35.5 \mathrm{GJ} / \mathrm{hr}$ & $33.6 \mathrm{MBtu} / \mathrm{hr}$ \\
Heat Input (LHV) & & $118,275 \mathrm{lb} / \mathrm{hr}$ \\
Exhaust Properties & $53,649 \mathrm{~kg} / \mathrm{hr}$ & $848^{\circ} \mathrm{F}$ \\
Mass Flow Rate (total) & $453{ }^{\circ} \mathrm{C}$ & $2,642 \mathrm{~kW}$ \\
Temperature & $2,642 \mathrm{~kW}$ & \\
Generator Gross Output, (each) & & \\
\hline
\end{tabular}


The OGT2500 offers distinct technical advantages over other engines. Unlike aero-derivative engines, it has been designed as an industrial engine with durability being one of the main design criteria and not weight. In addition to its ruggedness, the distinct "silo" type combustion system allows for easy access and modifications to the entire combustion system, which is one of the critical systems for the adaptation of the engine to bio-oil.

In addition to the engine design, important design modifications are necessary to compensate for the unique properties of bio-oil. These modifications will be discussed in order and based on the bio-oil properties listed in Table 3-16.

Bio-oil has an energy density approximately half that of diesel fuel. Therefore, to meet the same energy input requirement, the flow rate must be double. This requires design changes to the fuel system to be able to control higher flow rates and also modify the fuel nozzle to accommodate this larger flow. This lower energy density also can affect combustion since physically there must be twice as much fuel in the combustion chamber as with diesel. This, however, is another advantage of using an industrial engine in the fact that the combustion chambers are designed with a significantly longer residence time (and therefore a larger volume) for a given power output.

Higher viscosity of the fuel reduces the efficiency of atomization, which is critical to complete combustion. Large droplets take too long to burn. Proper atomization is addressed in three ways. Firstly, the fuel system is designed to deliver a high-pressure flow since atomization is improved with larger pressure drops across the fuel nozzle. Secondly, the fuel is pre-heated to lower the viscosity to acceptable levels. Thirdly and most importantly, the fuel nozzle has been redesigned to improve spray characteristics. These design improvements are important for complete combustion and effectively reducing $\mathrm{CO}$ emissions.

Due to its relatively low $\mathrm{pH}$, material selection is also critical for all components wetted by BioOil. This does not require the use of exotic materials; however, it does eliminate some standard fuel system materials. Typically, 300 series stainless steels are acceptable metallic materials and high-density polyethylene (HDPE) or fluorinated HDPE for polymers.

Although looked at as a contaminant for diesel fuel, the water content in bio-oil has some advantages. Firstly, it is helpful in reducing the viscosity, since it is a relatively low viscosity fluid. As well, it is a factor in lowering thermal $\mathrm{NO}_{\mathrm{x}}$ emissions.

The solids content is a combination of ash and char fines which have carried-over to the liquid part of the bio-oil. The effect of these solids is to cause sticking of close tolerance surfaces. They can result in particulate emissions because of the long residence 
time required to fully combust. It is important that the solids level in the bio-oil is controlled to be less than $0.1 \mathrm{wt} \%$.

The ash content in the fuel represents the material that cannot be combusted. Depending on the elements in the ash, it can result as a deposit on the hot gas path components that will reduce the turbine efficiency. This operational problem is a familiar one with the use of low-grade fuel oils that also have high ash content. The solution is a turbine wash system. This typically consists of two separate systems in which an abrasive medium is injected during operation to physically 'scrub' off the deposits. This allows turbine cleaning without any downtime. The second system is an offline process, which injects a cleaning fluid and allows a soak period to loosen the deposits that are then removed when the engine is started.

Within the ash are alkali elements that can result in hot corrosion of the hot gas path components with sodium and potassium being the most critical elements found in bio-oil. These elements form low melting temperature compounds that, as a liquid, will stick to the hot gas path components and then react and corrode the component. This effect can be mitigated through the use of fuel additives. As with the turbine wash systems, this technology was developed for the use of heavy fuel oils in gas turbines and has been in use for decades. The concept is to inject specific elements that preferentially react with the alkali metals such that they do not liquefy. This both reduces the propensity to stick to a surface and also reduces or completely eliminates its rate of attack. In combination with the additives, hot section coatings are being developed specifically for the type of attack that may be associated with bio-oil.

Due to the poor ignition characteristics of bio-oil, one other key design requirement is a bio-oil specific ignition system or process. To overcome this, the OGT2500 system starts on diesel fuel flowing through the primary channel in the fuel nozzle. Following a warm-up period, bio-oil is fed into the secondary channel at an increasing rate while the diesel fuel flow is reduced until 100 percent bio-oil flow is achieved.

Polymerization is also a key issue with bio-oil. This is the growing of molecular chains that can result in an increase in fuel viscosity. This process is highly dependent on the char level, time and temperature. For example, the equivalent change in properties can be achieved in 6 months at room temperature, compared to 8 hours at $90^{\circ} \mathrm{C}$ (R.G. Andrews et al., 1997). Therefore, as part of the fuel and combustion system design, maximum temperatures and fuel re-circulating are carefully controlled to ensure polymerization is maintained at a rate that is inconsequential to engine operation. 


\subsubsection{Combustion Turbine Testing}

DynaMotive and Orenda Aerospace have been cooperating on development of the OGT2500 for applications with bio-oil. A first generation fuel system and combustion system were designed and tested, demonstrating the capability to operate a $2.5 \mathrm{MW}$ industrial gas turbine on bio-oil (P. Gogolek et al., 1999). These tests not only revealed the feasibility of operation but also demonstrated that similar performance could be achieved for bio-oil and diesel. Although $\mathrm{CO}$ and particulate emissions were comparable to diesel, testing revealed that $\mathrm{NO}_{\mathrm{x}}$ emissions were about half that from diesel fuel and the $\mathrm{SO}_{2}$ emissions levels were so low as to be undetectable by the instrumentation.

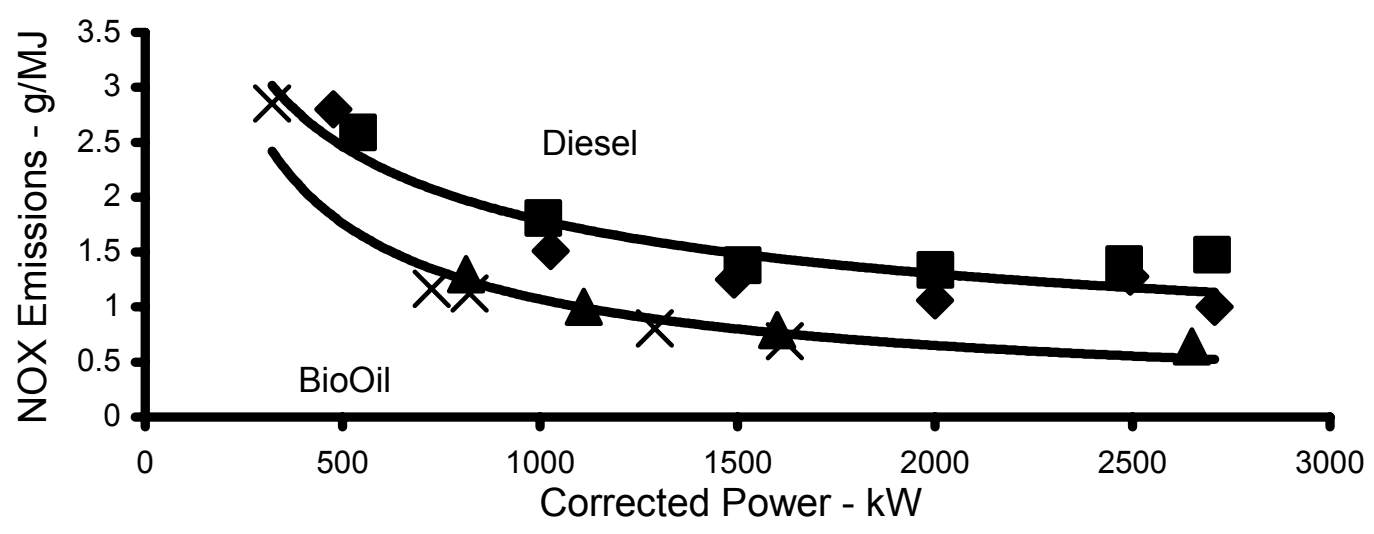

Figure 3-14. Pyrolysis Oil NO $_{\mathrm{x}}$ Emission Reduction.

\subsection{Rankine Steam Cycle Design}

By capturing the energy of the hot exhaust from the combustion turbine, additional power can be generated in a combined cycle configuration. This section discusses the steam or "Rankine" cycle portion of the combined cycle. This section also provides a heat and mass balance for the overall combined cycle and defines efficiency measures for the IPCC power plant.

\subsubsection{Rankine Steam Cycle Overview}

In comparison to other portions of the IPPC power plant, the Rankine steam cycle is relatively conventional technology with minimal technical risk. The steam cycle recovers the energy in the hot gases of the combustion turbine thereby raising steam in a heat recovery steam generator (HRSG). The steam from the HRSG is used to rotate a steam turbine generator and produce electrical power. The exhaust from the steam turbine is cooled until the water condenses, whereupon it is returned to the HRSG to be heated again. Heat is rejected from the condenser via a cooling tower. An alternative 
approach would be to send the turbine exhaust steam to a district heating loop or an industrial steam user. In this manner the heat could be put to a productive use thereby raising cycle efficiency. However, such applications are site specific and were not evaluated in this general study.

\subsubsection{Design Approach}

Early configurations of the Rankine steam cycle were designed to maximize efficiency and power output. Items such as a dual pressure level HRSG, high steam pressures and temperatures, and mid-stage steam admission to the steam turbine were included. These features resulted in a combined cycle design of over 41 percent efficiency with a net power block output of $8.43 \mathrm{MW}$. However, at the small sizes contemplated here, these design choices are non-standard and often result in significant cost premiums versus more conventional designs. For example, indicative estimates from vendors showed that a steam turbine with a throttle pressure of $6,200 \mathrm{kPa}(900 \mathrm{psia})$ costs nearly three times as much as a turbine with a $4,140 \mathrm{kPa}(600 \mathrm{psia})$ throttle pressure (\$2.5 million compared to $\$ 850,000$ ). Further, this cost differential does not include the additional costs for the higher pressure HRSG, pumps, piping, and other balance of plant equipment. Based on these considerations, a compromise design was selected that balances efficiency with cost. These changes resulted in a cycle design of about 37 percent efficiency with a net combined cycle power block output of 7.66 MW. Even at this reduced efficiency, the design is much more efficient than conventional biomass power plants, which often struggle to meet 20 percent efficiency in this size range.

\subsubsection{Combined Cycle Heat and Mass Balance}

Based on the design choices selected above, a heat and mass balance of the combined cycle portion of the plant was prepared using the GateCycle software. A summary of this heat balance is presented in Table 3-19. Based on the GateCycle model, the net power output from the combined cycle portion of the plant is estimated to be $7,660 \mathrm{~kW}$. The heat input to the gas turbines is $70.9 \mathrm{GJ} / \mathrm{h}(67.2 \mathrm{MBtu} / \mathrm{h})$ on a lower heating value basis (LHV). A small amount of additional heat is added to the cycle from the exhaust of the pyrolysis plant (the pyrolyzer indirect heating gas stream). This amounts to $2.6 \mathrm{GJ} / \mathrm{h}(2.5 \mathrm{MBtu} / \mathrm{h})$. With a total heat input of $73.6 \mathrm{GJ} / \mathrm{hr}(69.8 \mathrm{MBtu} / \mathrm{h})$ (LHV), the estimated combined cycle net plant heat rate (LHV) is $9,610 \mathrm{~kJ} / \mathrm{kWh}(9,110$ $\mathrm{Btu} / \mathrm{kWh}$ ). This is equivalent to 37.5 percent efficiency. This efficiency measures the combined cycle portion of the project only and does not include the efficiency of the pyrolyzer in converting the solid biomass fuel into bio-oil. This is discussed further in the next section. 
Table 3-19. Combined Cycle Heat and Mass Balance.

\begin{tabular}{|c|c|c|}
\hline $\begin{array}{l}\text { Fuel } \\
\text { Ambient Temperature } \\
\text { Number of CTG/HRSG Units Operating } \\
\text { STG Throttle Conditions } \\
\text { Condenser Pressure } \\
\end{array}$ & $\begin{array}{c}\text { Bio-Oil } \\
15 \mathrm{C} \\
2 \mathrm{kPa} / \mathrm{C} \\
4140 / 340 \mathrm{~km} \\
103.429 \mathrm{mmHgA} \\
\end{array}$ & $\begin{array}{c}\text { Bio-Oil } \\
59 \text { F } \\
2 \text { psia/F } \\
600 / 650 \text { pin } \\
4.072 \text { in } \mathrm{HgA} \\
\end{array}$ \\
\hline New \& Clean Performance Summary & & \\
\hline Number of CTG Operating & 2 & 2 \\
\hline $\begin{array}{l}\text { Gross CTG Output (each) } \\
\text { Gross CTG Output (total) }\end{array}$ & $\begin{array}{ll}2,642 & \mathrm{~kW} \\
5,284 & \mathrm{~kW}\end{array}$ & $\begin{array}{ll}2,642 & \mathrm{~kW} \\
5,284 & \mathrm{~kW}\end{array}$ \\
\hline Gross CTG Heat Rate (LHV) & $13,426 \mathrm{~kJ} / \mathrm{kWh}$ & $12,727 \quad \mathrm{Btu} / \mathrm{kWh}$ \\
\hline Total CTG Heat Input (LHV) & $70.9 \mathrm{GJ} / \mathrm{h}$ & $67.2 \mathrm{MBtu} / \mathrm{h}$ \\
\hline Heat Input - Pyrolyzer Indirect Heating Gas Exhaust & $2.6 \mathrm{GJ} / \mathrm{h}$ & $2.5 \mathrm{MBtu} / \mathrm{h}$ \\
\hline $\begin{array}{l}\text { Gross STG Output } \\
\text { STG Output, percent of CTG Output }\end{array}$ & $\begin{array}{c}2,566 \mathrm{~kW} \\
48.6 \%\end{array}$ & $\begin{array}{c}2,566 \mathrm{~kW} \\
48.6 \%\end{array}$ \\
\hline $\begin{array}{l}\text { Gross Plant Output } \\
\text { Gross Cycle Heat Rate (LHV) }\end{array}$ & $\begin{array}{ll}7,850 & \mathrm{~kW} \\
9,037 & \mathrm{~kJ} / \mathrm{kWh}\end{array}$ & $\begin{array}{ll}7,850 & \mathrm{~kW} \\
8,567 & \mathrm{Btu} / \mathrm{kWh} \\
\end{array}$ \\
\hline $\begin{array}{l}\text { Auxiliary Power/Losses } \\
\text { Auxiliary Power/Losses, percent of gross }\end{array}$ & $\begin{array}{c}195 \mathrm{~kW} \\
2.48 \%\end{array}$ & $\begin{array}{c}195 \mathrm{~kW} \\
2.48 \% \\
\end{array}$ \\
\hline Combined Cycle Plant Heat Input, MBtu/h (LHV) & $73.6 \quad \mathrm{GJ} / \mathrm{h}$ & 69.8 MBtu/h \\
\hline $\begin{array}{l}\text { Net Combined Cycle Plant Output } \\
\text { Net Combined Cycle Plant Heat Rate (LHV) }\end{array}$ & $\begin{array}{ll}7,655 & \mathrm{~kW} \\
9,613 \mathrm{~kJ} / \mathrm{kWh}\end{array}$ & $\begin{array}{l}7,655 \mathrm{~kW} \\
9,112 \mathrm{Btu} / \mathrm{kWh}\end{array}$ \\
\hline Net Combined Cycle Plant Efficiency (LHV) & $37.5 \%$ & $37.5 \%$ \\
\hline Combustion Turbine Generator (per unit) & & \\
\hline $\begin{array}{l}\text { Ambient Conditions } \\
\text { Barometric Pressure } \\
\text { Dry Bulb Temperature } \\
\text { Relative Humidity } \\
\text { Wet Bulb Temperature } \\
\text { Humidity Ratio } \\
\text { Fuel Parameters } \\
\text { Fuel Flow } \\
\text { Heat Input (LHV) } \\
\text { Exhaust Properties } \\
\text { Mass Flow rate } \\
\text { Temperature } \\
\text { Generator Gross Output, kW (each) }\end{array}$ & $\begin{array}{rl}101.4 & \mathrm{kPa} \\
15.0 \mathrm{C} \\
60.00 \% \\
10.81 \mathrm{C} \\
0.63 \% \\
\\
2,073 \mathrm{~kg} / \mathrm{h} \\
35.5 \mathrm{GJ} / \mathrm{h} \\
\\
53,649 . & \mathrm{kg} / \mathrm{h} \\
453 & \mathrm{C} \\
2,642 & \mathrm{~kW} \\
\end{array}$ & $\begin{array}{rl}14.7 & \text { psia } \\
59 & \mathrm{~F} \\
60.00 \% \\
51.47 & \mathrm{~F} \\
0.63 \% \\
& \\
4,569 & \mathrm{lb} / \mathrm{h} \\
33.6 & \mathrm{MBtu} / \mathrm{h} \\
& \\
118,275 . & \mathrm{lb} / \mathrm{h} \\
848 & \mathrm{~F} \\
2,642 & \mathrm{~kW} \\
\end{array}$ \\
\hline Heat Recovery Steam Generator (per unit) & & \\
\hline $\begin{array}{l}\text { HP Superheater Gas Side Parameters } \\
\text { Inlet } \\
\begin{array}{ll}\text { Mass Flow rate } \\
\text { Pressure } \\
\text { Temperature } \\
\text { Enthalpy }\end{array}\end{array}$ & $\begin{array}{rl}107,299 . & \mathrm{kg} / \mathrm{h} \\
101.4 & \mathrm{kPa} \\
453.27 & \mathrm{C} \\
478.0 & \mathrm{~kJ} / \mathrm{kg}\end{array}$ & $\begin{array}{rl}236,551 . & \mathrm{lb} / \mathrm{h} \\
14.7 & \mathrm{psia} \\
847.89 & \mathrm{~F} \\
205.5 & \mathrm{Btu} / \mathrm{lb}\end{array}$ \\
\hline
\end{tabular}


Table 3-19. Combined Cycle Heat and Mass Balance.

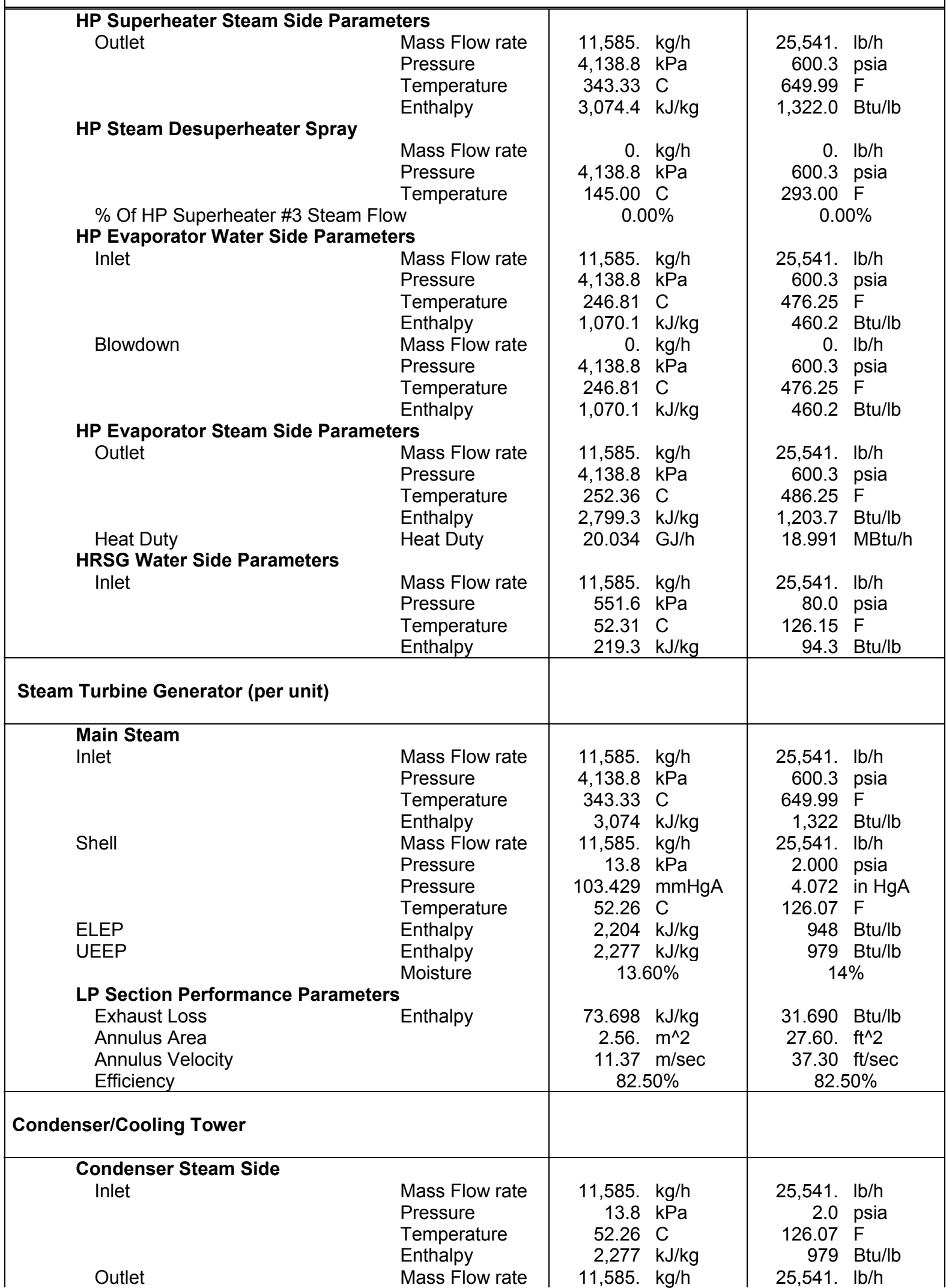


Table 3-19. Combined Cycle Heat and Mass Balance.

\begin{tabular}{|c|c|c|c|}
\hline $\begin{array}{l}\text { Heat Duty } \\
\text { Condenser Water Side } \\
\text { Inlet } \\
\text { Outlet } \\
\text { Heat Duty }\end{array}$ & $\begin{array}{l}\text { Pressure } \\
\text { Temperature } \\
\text { Enthalpy } \\
\text { Heat Duty } \\
\text { Mass Flow rate } \\
\text { Pressure } \\
\text { Temperature } \\
\text { Enthalpy } \\
\text { Mass Flow rate } \\
\text { Pressure } \\
\text { Temperature } \\
\text { Heat Duty }\end{array}$ & $\begin{array}{rl}13.8 & \mathrm{kPa} \\
52.26 & \mathrm{C} \\
218.7 & \mathrm{~kJ} / \mathrm{kg} \\
23.849 & \mathrm{GJ} / \mathrm{h} \\
& \\
512,828 & \mathrm{~kg} / \mathrm{h} \\
103.4 & \mathrm{kPa} \\
15.56 & \mathrm{C} \\
65.4 & \mathrm{~kJ} / \mathrm{kg} \\
512,828 & \mathrm{~kg} / \mathrm{h} \\
103.4 & \mathrm{kPa} \\
26.67 & \mathrm{C} \\
23.853 & \mathrm{GJ} / \mathrm{h} \\
\end{array}$ & $\begin{array}{rl}2.0 & \mathrm{psia} \\
126.07 & \mathrm{~F} \\
94.0 & \mathrm{Btu} / \mathrm{lb} \\
22.608 & \mathrm{Mbtu} / \mathrm{h} \\
& \\
1,130,581 & \mathrm{lb} / \mathrm{h} \\
15.0 & \mathrm{psia} \\
60.00 & \mathrm{~F} \\
28.1 & \mathrm{Btu} / \mathrm{lb} \\
1,130,581 & \mathrm{lb} / \mathrm{h} \\
15.0 & \mathrm{psia} \\
80.00 & \mathrm{~F} \\
22.612 & \mathrm{Mbtu} / \mathrm{h}\end{array}$ \\
\hline \multicolumn{4}{|l|}{ Miscellaneous } \\
\hline \multicolumn{4}{|l|}{ Boiler Feed Pump } \\
\hline Suction & $\begin{array}{l}\text { Mass Flow rate } \\
\text { Pressure } \\
\text { Temperature } \\
\text { Enthalpy }\end{array}$ & $\begin{array}{rl}11,585 . & \mathrm{kg} / \mathrm{h} \\
551.6 & \mathrm{kPa} \\
144.44 & \mathrm{C} \\
608.3 & \mathrm{~kJ} / \mathrm{kg} \\
\end{array}$ & $\begin{array}{rl}25,541 . & \mathrm{lb} / \mathrm{h} \\
80.0 & \mathrm{psia} \\
292.00 & \mathrm{~F} \\
261.6 & \mathrm{Btu} / \mathrm{lb}\end{array}$ \\
\hline Discharge & $\begin{array}{l}\text { Mass Flow rate } \\
\text { Pressure } \\
\text { Temperature } \\
\text { Enthalpy }\end{array}$ & $\begin{array}{rl}11,585 . & \mathrm{kg} / \mathrm{h} \\
4,138.8 & \mathrm{kPa} \\
145.00 & \mathrm{C} \\
612.9 & \mathrm{~kJ} / \mathrm{kg} \\
\end{array}$ & $\begin{array}{rl}25,541 . & \mathrm{lb} / \mathrm{h} \\
600.3 & \mathrm{psia} \\
293.00 & \mathrm{~F} \\
263.5 & \mathrm{Btu} / \mathrm{lb} \\
\end{array}$ \\
\hline \multicolumn{4}{|c|}{ HP BFP Performance Parameters } \\
\hline \multicolumn{4}{|l|}{ Condensate Pump } \\
\hline Suction & $\begin{array}{l}\text { Mass Flow rate } \\
\text { Pressure } \\
\text { Temperature } \\
\text { Enthalpy }\end{array}$ & $\begin{array}{rl}11,585 . & \mathrm{kg} / \mathrm{h} \\
13.8 & \mathrm{kPa} \\
52.26 & \mathrm{C} \\
218.7 & \mathrm{~kJ} / \mathrm{kg}\end{array}$ & $\begin{array}{rl}25,541 . & \mathrm{lb} / \mathrm{h} \\
2.0 & \mathrm{psia} \\
126.07 & \mathrm{~F} \\
94.0 & \mathrm{Btu} / \mathrm{lb}\end{array}$ \\
\hline Discharge & $\begin{array}{l}\text { Mass Flow rate } \\
\text { Pressure } \\
\text { Temperature } \\
\text { Enthalpy }\end{array}$ & $\begin{array}{rl}11,585 . & \mathrm{kg} / \mathrm{h} \\
551.6 & \mathrm{kPa} \\
52.31 & \mathrm{C} \\
219.3 & \mathrm{~kJ} / \mathrm{kg}\end{array}$ & $\begin{array}{rl}25,541 . & \mathrm{lb} / \mathrm{h} \\
80.0 & \mathrm{psia} \\
126.15 & \mathrm{~F} \\
94.3 & \mathrm{Btu} / \mathrm{lb} \\
\end{array}$ \\
\hline \multicolumn{4}{|c|}{ Condensate Pump Performance Parameters } \\
\hline Isentropic Efficiency & & $85.00 \%$ & $85.00 \%$ \\
\hline
\end{tabular}

\subsubsection{Overall Process Efficiency Calculations}

Measurement of the overall process efficiency (for example, solid biomass to electric power) is not straightforward in this application for several reasons:

- The pyrolysis process and combined cycle operate at different capacity factors. The pyrolysis process is expected to operate slightly more often than the combined cycle (90.4 versus 80 percent capacity factor). For this reason, the hourly throughputs of the two plants are slightly different. A bio-oil storage tank allows for temporary storage. The storage component makes calculation of a "steady-state" efficiency difficult. 
- Approximately twenty percent of the incoming biomass is converted to char. The char, which has value as a fuel or as a possible feedstock for activated carbon production, is not consumed in the pyrolysis process.

- Approximately twenty percent of the pyrolysis plant bio-oil production could be used to produce anhydrosugars. Anhydrosugars are a value-added product that is exported off-site. Anhydrosugar production will therefore significantly limit bio-oil fuel for the gas turbine and lower power output.

- A possible permutation of the process may involve several remote, distributed pyrolysis plants and power plants. These plants will be operated on different schedules to meet the needs of the different applications.

None of these represents limitations of the IPCC concept; rather, they all convey certain advantages. For this reason, the project team proposes three different measures of efficiency, as described below.

Net combined cycle efficiency, which measures the efficiency of the combined cycle in converting bio-oil (and a small amount of waste heat from the pyrolysis plant) to electrical power. The net combined cycle efficiency is calculated as:

$\frac{\text { net combined cycle }(\mathrm{CC}) \text { power output, } \mathrm{kW}}{(\text { bio - oil flow, } \mathrm{kg} / \mathrm{hr})(\text { bio }- \text { oil } \mathrm{HV}, \mathrm{kJ} / \mathrm{kg})+(\text { waste heat input from pyrolyzer to } \mathrm{CC}, \mathrm{kj} / \mathrm{hr})}$

Table 3-20 shows the calculated net combined cycle efficiency to be 37.5 percent (lower heating value basis).

Table 3-20. Net Combined Cycle Efficiency Calculations (LHV basis).

\begin{tabular}{|c|c|c|c|c|}
\hline Heat Input & \multicolumn{2}{|c|}{ Metric Units } & \multicolumn{2}{|c|}{ English Units } \\
\hline Bio-oil mass flow & 4,145 & $\mathrm{~kg} / \mathrm{hr}$ & 9,139 & $\mathrm{lb} / \mathrm{hr}$ \\
\hline Bio-oil heating value & 17,114 & $\mathrm{~kJ} / \mathrm{kg}$ & 7,359 & $\mathrm{Btu} / \mathrm{lb}$ \\
\hline Bio-oil heat input & 70.9 & $\mathrm{GJ} / \mathrm{hr}$ & 67.2 & $\mathrm{MBtu} / \mathrm{hr}$ \\
\hline Pyrolyzer waste heat input & 2.6 & $\mathrm{GJ} / \mathrm{hr}$ & 2.5 & $\mathrm{MBtu} / \mathrm{hr}$ \\
\hline Total combined cycle heat input & 73.6 & $\mathrm{GJ} / \mathrm{hr}$ & 69.8 & $\mathrm{MBtu} / \mathrm{hr}$ \\
\hline \multicolumn{5}{|l|}{ Power } \\
\hline Gross combined cycle power output & 7,850 & $\mathrm{~kW}$ & 7,850 & $\mathrm{~kW}$ \\
\hline Net combined cycle power output & 7,655 & $\mathrm{~kW}$ & 7,655 & $\mathrm{~kW}$ \\
\hline \multicolumn{5}{|l|}{ Efficiency } \\
\hline Net combined cycle heat rate & 9,613 & $\mathrm{GJ} / \mathrm{kWh}$ & 9,112 & $\mathrm{Btu} / \mathrm{kWh}$ \\
\hline Net combined cycle efficiency & $37.5 \%$ & percent & $37.5 \%$ & percent \\
\hline
\end{tabular}


Annual average total fuel cycle efficiency, which measures the overall efficiency of the IPCC plant in converting solid biomass (and a small amount of supplemental natural gas) to electrical power. This ratio is calculated on an annual basis to compensate for the different capacity factors of the pyrolysis and combined cycle plants. It assumes that on an annual basis, all of the bio-oil produced by the pyrolysis plant is consumed by the combined cycle. It does not account for the energy in the char or anhydrosugar. The annual average total fuel cycle efficiency is calculated as:

(annual net CC power production, kWh/yr) - (annual pyrolysis plant power consumption, kWh/yr) (biomass consumption, $\mathrm{kg} / \mathrm{yr}$ ) (biomass $\mathrm{HV}, \mathrm{kJ} / \mathrm{kg}$ ) + (natural gas heat input, kJ/yr)

Table 3-21 shows the annual average total fuel cycle efficiency to be 22.2 percent (lower heating value basis).

Table 3-21. Annual Average Total Fuel Cycle Efficiency Calculations (LHV).

\section{Heat Input}

Pyrolysis plant capacity factor

Biomass consumption (wet), design hourly

Biomass consumption (wet), annual

Biomass heating value

Biomass heat input, design hourly

Natural gas heat input, design hourly

Total IPCC heat input, design hourly

Biomass heat input, annual

Natural gas heat input, annual

Total IPCC heat input, annual

\section{Power}

Combined cycle capacity factor

Net combined cycle power output

Annual combined cycle power production

Pyrolysis plant power consumption

Pyrolysis plant capacity factor

Annual pyrolysis plant power consumption

Total annual IPCC net power production

\section{Efficiency}

Annual average total fuel cycle heat rate

Annual average total fuel cycle efficiency

\begin{tabular}{|rl|rl|}
\hline Metric Units & \multicolumn{2}{|c|}{ English Units } \\
90.4 & percent & 90.4 & percent \\
5.39 & tonne/hr & 5.94 & ton $/ \mathrm{hr}$ \\
42,705 & tonne/yr & 47,074 & ton $/ \mathrm{yr}$ \\
15,665 & $\mathrm{~kJ} / \mathrm{kg}$ & 6,732 & $\mathrm{Btu} / \mathrm{lb}$ \\
84.5 & $\mathrm{GJ} / \mathrm{hr}$ & 80 & $\mathrm{MBtu} / \mathrm{hr}$ \\
5.8 & $\mathrm{GJ} / \mathrm{hr}$ & 5.5 & $\mathrm{MBtu} / \mathrm{hr}$ \\
90.3 & $\mathrm{GJ} / \mathrm{hr}$ & 85.5 & $\mathrm{MBtu} / \mathrm{hr}$ \\
668,989 & $\mathrm{GJ} / \mathrm{yr}$ & 633,801 & $\mathrm{MBtu} / \mathrm{yr}$ \\
46,150 & $\mathrm{GJ} / \mathrm{yr}$ & 43,748 & $\mathrm{MBtu} / \mathrm{yr}$ \\
715,139 & $\mathrm{GJ} / \mathrm{yr}$ & 677,549 & $\mathrm{MBtu} / \mathrm{yr}$ \\
& & & \\
80 & $\mathrm{percent}$ & 80 & $\mathrm{percent}$ \\
7,655 & $\mathrm{~kW}$ & 7,655 & $\mathrm{~kW}$ \\
53.6 & $\mathrm{GWh} / \mathrm{yr}$ & 53.6 & $\mathrm{GWh} / \mathrm{yr}$ \\
1,197 & $\mathrm{~kW}$ & 1,197 & $\mathrm{~kW}$ \\
90.4 & $\mathrm{percent}$ & 90.4 & $\mathrm{percent}$ \\
9.5 & $\mathrm{GWh} / \mathrm{yr}$ & 9.5 & $\mathrm{GWh} / \mathrm{yr}$ \\
44.1 & $\mathrm{GWh} / \mathrm{yr}$ & 44.1 & $\mathrm{GWh} / \mathrm{yr}$ \\
& & & \\
16,198 & $\mathrm{GJ} / \mathrm{kWh}$ & 15,347 & $\mathrm{Btu} / \mathrm{kWh}$ \\
$22.2 \%$ & $\mathrm{percent}$ & $22.2 \%$ & $\mathrm{percent}$ \\
\hline
\end{tabular}


Corrected annual average total fuel cycle efficiency, which measures the efficiency of the IPCC plant in converting a portion of the overall solid biomass consumption (and a small amount of supplemental natural gas fuel) to net electrical power. The value used for the biomass consumption excludes the biomass used to produce value-added byproducts (that is, char and anhydrosugar). Further, the electrical and natural gas consumption of the pyrolysis plant are pro-rated for their applicability to bio-oil production. An equation for the corrected annual average total fuel cycle efficiency has not been developed at this time. 


\subsection{Fuel Supply Availability and Cost}

The state of Iowa was selected for establishing fuel supply availability and cost because of Alliant Energy's large service territory within the state and Iowa's desire to produce renewable energy from abundant indigenous fuel resources. Iowa is a state rich in agricultural resources that provide potential sources for biomass fuel. Biomass sources available in Iowa include herbaceous energy crops (HEC) like switchgrass, short-rotation woody crops (SRWC) such as poplar trees, forestry residues, wood by-products, animal manure, crop residues, municipal solid waste, and sewage sludge.

Iowa could become a world leader in the development of biomass fuels as a renewable energy resource because of its large quantity of agricultural products and a proficient agricultural knowledge base. The state has an estimated total biomass production of $4.3 \times 10^{5} \mathrm{TJ}\left(4.06 \times 10^{14} \mathrm{Btu}\right)$ with corn crop residue making up the largest portion of about 42 percent while herbaceous and short-rotation energy crops contribute about 22 percent each. The remainder is made up of animal and other wastes. In addition, Iowa has about $2.66 \times 10^{6}$ acres of marginal land (Land Capability Classification or LCC IV to VII) that is currently used for crop production or considered to be non-Conservation Reserve Program (CRP)/Wetlands Reserve Program (WRP) pasturelands. If this marginal land were committed to dedicated HEC or woody biomass crops production, an additional $2.2 \times 10^{5} \mathrm{TJ} / \mathrm{yr}\left(2.1 \times 10^{14} \mathrm{Btu} / \mathrm{yr}\right)$ of biomass energy could be obtained from this land (Brown, Hallam, et al., 2001). Based on the compatibility and availability, both corn stover and oat hulls were selected as the choice fuels for this study. This section explores the properties, availability, and cost of using these resources.

\subsection{Corn Stover}

Corn stover represents Iowa's largest biomass resource. On an annual basis, about 11.5 million tons of corn stover is theoretically available for energy production. Based on a heating value of about $17.4 \mathrm{MJ} / \mathrm{kg}(7,500 \mathrm{Btu} / \mathrm{lb})$, this translates into approximately $2 \times 10^{5} \mathrm{TJ} / \mathrm{yr}\left(1.7 \times 10^{14} \mathrm{Btu} / \mathrm{yr}\right)$, which is sufficient to provide heating and electricity requirements to slightly over 1 million homes annually (Iowa DNR, 2002). However, due to the current inefficient collection methods, the price of corn stover may be so high as to make it an infeasible energy source.

Recently, Iron Horse Custom Farms (IHCF) in Harlan, IA implemented the first large-scale corn stover collection operations, approaching 100,000 acres. The study team reviewed the IHCF 1999 Corn Stover Harvest Report, and used its findings as a basis to determine the feasibility of corn stover as potential biomass fuel in Iowa. 


\subsubsection{Corn Stover Fuel Properties}

Fuel properties have significant impacts on the technical and financial viability of biomass fueled power plants. Discussions of corn stover properties are outlined in the following subsections.

\subsubsection{Physical Properties}

Corn stover is essentially the remains of the corn harvest, which is made up of the leaves, husks, stalks, and corncobs. Figure 4-1 illustrates the remnants of corn stover in a field after the corn has been harvested. Corn stover is typically baled in round or square bales; Figure 4-2 illustrates the square bale method.

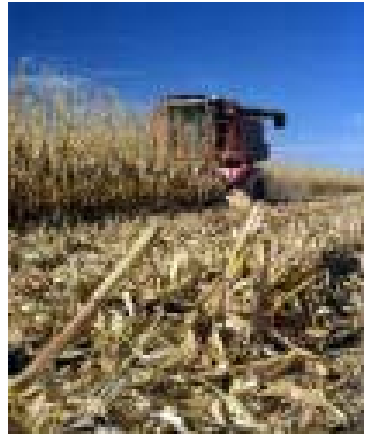

Figure 4-1. Corn Stover Remnants.

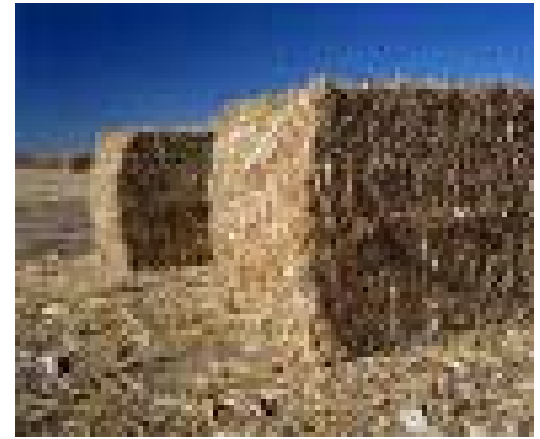

Figure 4-2. Square Baled Corn Stover.

\subsubsection{Moisture Content}

One major concern with corn stover is its moisture content. With increased moisture content, deterioration of the stover becomes a major concern. In addition, moisture in the feedstock for the pyrolysis process is undesirable as it lowers the quality of the bio-oil. The moisture content of corn stover at harvest is generally at about 35 percent. After three days of dry weather the moisture content usually drops below 20 percent (Schechinger et al., 09/30/1999). However, desired moisture content upon delivery to the plant is not always guaranteed.

The main reason farmers cannot guarantee moisture content is due to the variability in weather conditions. In addition, farmers generally do not have the necessary moisture testing equipment to measure the moisture content of corn stover. As a general rule, the lower the moisture content required the higher the cost of the corn stover. By lowering the moisture content requirement of the corn stover there is a much smaller window during which the corn stover can be harvested thereby raising the cost of the fuel. Therefore, a moisture criterion must be set that balances the fuel costs with the desired output of the plant. 
Another consideration to moisture content is the collection process. There are two common methods of collecting the corn stover, either by a windrow left by the combine or by raking the corn stover. Raking methods allow for better moisture control, given that evenly distributed corn stover will dry faster than the alternative windrow method should it rain.

\subsubsection{Contaminants}

The presence of contaminants in corn stover is also a major concern. These contaminants, which include dirt and rocks, make up about 2 to 5 percent of the total weight of corn stover. They can be very destructive to bailing equipment and power plant system components, and can increase operation and maintenance (O\&M) costs substantially. Rocks and gravel can be avoided to a degree during collection by flailing the corn stover high and keeping the rake off of the surface of the soil. Nevertheless, current corn stover collection methods do not eliminate these contaminants. During the bailing process or when mobile collection equipment travels over corn stover, dirt and soil clods can easily be mixed with corn stover.

\subsubsection{Chemical Properties}

Table 4-1 provides the chemical properties of the different components of corn stover. For this report, the as-fired (6.1 percent moisture) higher heating value of corn stover is assumed to be $16,754 \mathrm{~kJ} / \mathrm{kg}(7,200 \mathrm{Btu} / \mathrm{lb})$. The lower heating value is 15,665 $\mathrm{kJ} / \mathrm{kg}(6,730 \mathrm{Btu} / \mathrm{lb})$. 
Table 4-1. Corn Stover Analysis.

\begin{tabular}{|c|c|c|c|c|c|c|}
\hline & \multicolumn{2}{|c|}{ Seed Corn } & \multicolumn{2}{|c|}{ Corn Cobs } & \multicolumn{2}{|c|}{ Corn Husks } \\
\hline & As Rec. & Dry & As Rec. & Dry & As Rec. & Dry \\
\hline \multicolumn{7}{|l|}{ Proximate Analysis, percent: } \\
\hline Moisture & 9.0 & 0.0 & 4.2 & 0.0 & 6.5 & 0.0 \\
\hline Volatile Matter & 77.9 & 85.6 & 77.2 & 80.6 & 75.1 & 80.3 \\
\hline Fixed Carbon & 11.7 & 12.9 & 12.9 & 17.4 & 16.0 & 17.1 \\
\hline Ash & 1.4 & 1.5 & 1.2 & 1.3 & 2.4 & 2.6 \\
\hline \multicolumn{7}{|l|}{ Ultimate Analysis, percent: } \\
\hline $\mathrm{C}$ & 41.7 & 45.82 & 44.92 & 46.89 & 42.46 & 45.41 \\
\hline $\mathrm{N}$ & 6.43 & 5.96 & 5.66 & 5.42 & 5.89 & 5.52 \\
\hline $\mathrm{H}$ & 1.10 & 1.21 & 0.95 & 0.99 & 0.61 & 0.65 \\
\hline S & 0.13 & 0.14 & 0.07 & 0.07 & 0.06 & 0.06 \\
\hline $\mathrm{O}^{*}$ & 49.24 & 45.37 & 47.20 & 45.33 & 48.58 & 45.76 \\
\hline \multicolumn{7}{|l|}{ Trace Elements } \\
\hline $\mathrm{Cl}(\mathrm{ppm})^{* *}$ & \multicolumn{2}{|c|}{498} & \multicolumn{2}{|c|}{1640} & \multicolumn{2}{|c|}{1648} \\
\hline $\mathrm{K}$ (percent) ${ }^{* *}$ & \multicolumn{2}{|c|}{0.37} & \multicolumn{2}{|c|}{1.1} & \multicolumn{2}{|c|}{1.0} \\
\hline $\mathrm{Na}(\mathrm{ppm})^{* * *}$ & \multicolumn{2}{|c|}{22} & \multicolumn{2}{|c|}{4} & \multicolumn{2}{|c|}{74} \\
\hline $\mathrm{Ca}$ (percent) & \multicolumn{2}{|c|}{0} & \multicolumn{2}{|c|}{0} & \multicolumn{2}{|c|}{0.14} \\
\hline
\end{tabular}

\subsubsection{Corn Stover Fuel Availability and Requirements}

Topics on corn stover availability and requirements for the IPCC facility are explored in the following subsections.

\subsubsection{Harvest Potential}

Based on 2001 Department of Agriculture Data, Iowa produced over 1.6 billion bushels of corn with an average yield of 361 bushels/ha (146 bushels/acre). It is estimated that the weight of corn stover produced during harvest is essentially equal to the weight of corn harvested (Schechinger et al., 1999). The weight of corn harvested also varies with its moisture content. The equivalent weight/bushel of grain at various moisture contents can be estimated using the following formula (University of Wisconsin, 2002): 


$$
\mathrm{EW}_{\text {Corn }}=\mathrm{DW}_{\text {Corn }}+\left[(\mathrm{M})\left(\mathrm{DW}_{\text {Corn })} /(100-\mathrm{M})\right]\right.
$$

Where:

$$
\begin{aligned}
& \mathrm{EW}_{\text {Corn }}=\text { Estimated Weight of Corn per Bushel at Moisture Content } \mathrm{M} \\
& \mathrm{DW}_{\mathrm{Corn}}=\text { Dry Weight of Corn per Bushel= } 21.5 \mathrm{~kg} / \text { bushel }(47.3 \\
& \text { pounds/bushel) } \\
& \mathrm{M}=\text { Moisture Content of the Corn (percent) }
\end{aligned}
$$

Using the formula above and on the basis of 15 percent corn moisture content and 1.6 billion bushels annual production, the equivalent weight of corn available for harvest is about 40 million tonne/yr (44 million ton/yr). With 100 percent collection efficiency, this translates into about 40 million tonnes/yr of wet corn stover. By taking into account the inefficiencies in the collection methods and the restriction imposed by Soil Conservation Service on harvesting stover from farms with slopes that are 6 percent more, the corn stover harvest yield is approximately 3.36 dry tonnes/ha (1.5 dry tons/acre).

Figure 4-3 and Figure 4-4 illustrate the amount of corn stover available in Iowa on a tonne basis and on a tonne $/ \mathrm{km}^{2}$ basis, respectively, assuming soil conservation practices and a harvest yield of 3.36 dry tonnes/ha (1.5 tons/acre). In addition, Figure 4-3 and Figure 4-4 also show the electric transmission lines and locations of Alliant Energy generation facilities.

\subsubsection{Stover Requirements}

For this study it was assumed that the combined cycle biomass plant would consume biomass fuel at 5.39 tonnes/hr $(5.94$ tons/hr), with the pyrolysis portion of the plant operating 330 days per year on average. Table 4-2 summarizes the corn stover requirements for the plant operations.

Depending on the hours of operation, the power plant will need at peak consumption 129 tonnes/day (143 tons/day), which equates to approximately 220 round bails of stover/day. Industry contacts indicated that 220 bails/day was attainable. Since stover has such a small harvest window on-site storage or field storage will need to be considered. 


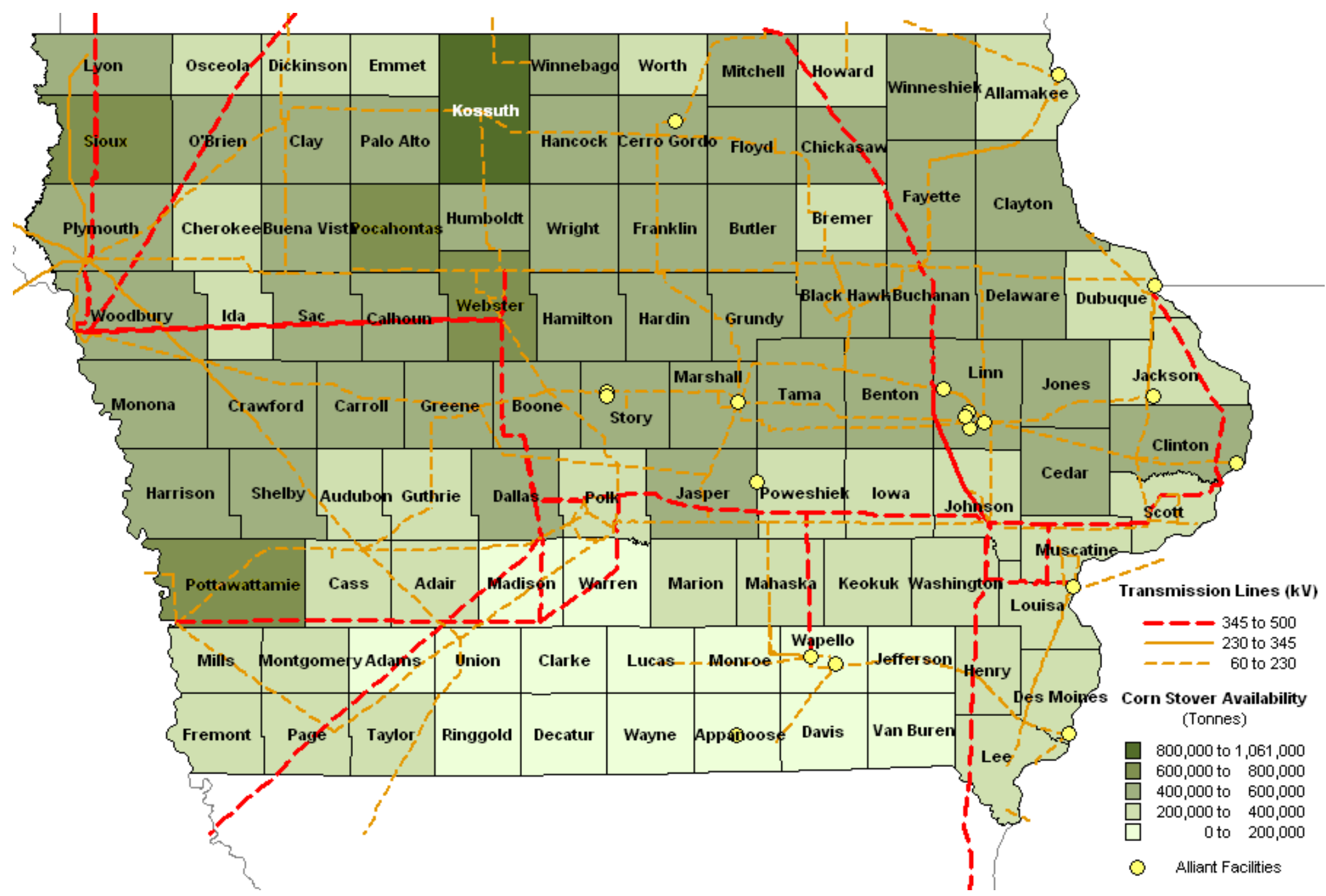

Figure 4-3. Annual Corn Stover Potential (tonnes). 


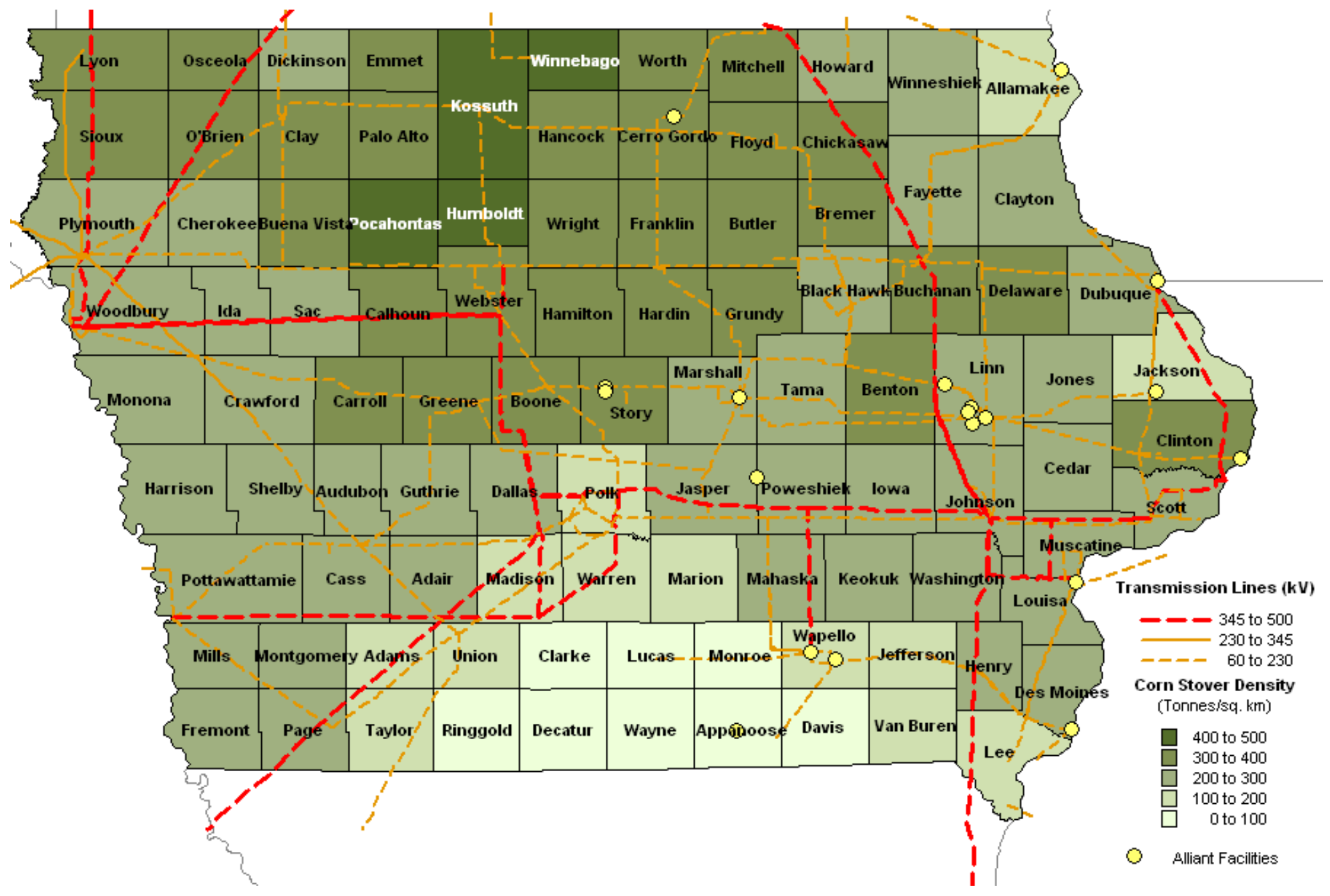

Figure 4-4. Annual Corn Stover Potential (tonnes $/ \mathbf{k m}^{2}$ ). 
Table 4-2. Corn Stover ${ }^{\mathrm{a}}$ Requirements for Pyrolysis Plant Operations.

\begin{tabular}{|c|c|c|}
\hline Item & Metric Units & English Units \\
\hline \multicolumn{3}{|l|}{ Design Capacity } \\
\hline Design Hourly Consumption & 5.39 tonne $/ \mathrm{hr}$ & $5.94 \mathrm{ton} / \mathrm{hr}$ \\
\hline Design Daily Consumption & 129 tonne/day & 143 ton/day \\
\hline \multicolumn{3}{|l|}{ Projected Average Consumption } \\
\hline Projected Pyrolysis Plant Capacity Factor ${ }^{\mathrm{b}}$ & 90.4 percent & 90.4 percent \\
\hline Projected Hourly Consumption & 4.88 tonne $/ \mathrm{hr}$ & $5.37 \mathrm{ton} / \mathrm{hr}$ \\
\hline Projected Daily Consumption & 117 tonne/day & 129 ton/day \\
\hline Projected Annual Consumption & 42,700 tonne/yr & 47,100 ton/yr \\
\hline Projected Annual Consumption (bone dry) & 40,100 tonne/yr & 44,200 ton/yr \\
\hline \multicolumn{3}{|l|}{ Farming Requirements } \\
\hline Stover Harvest Density ${ }^{\mathrm{c}}$ (bone dry) & 0.551 tonne/Ha & 1.5 ton/acre \\
\hline Required Harvest Acres (Annually) & $11,931 \mathrm{Ha}$ & 29,500 acre \\
\hline Average Iowa Farm Size ${ }^{d}$ & $139.6 \mathrm{Ha}$ & 345 acre \\
\hline Average Number of Farms Required & 85 & 85 \\
\hline \multicolumn{3}{|c|}{ Notes: } \\
\hline \multicolumn{3}{|c|}{$\begin{array}{l}\text { a Except as noted, refers to wet corn stover "as fired" at } 6 \text { percent moisture. } \\
\text { befers to pyrolysis portion of the cycle only. Combined cycle power generation } \\
\text { may operate on different schedule. }\end{array}$} \\
\hline
\end{tabular}

\subsubsection{Storage}

Storage is another key aspect to the feasibility of using corn stover as a potential fuel. Assuming that the plant operates with a fuel rate of $5.39 \mathrm{tonne} / \mathrm{hr}(5.94 \mathrm{ton} / \mathrm{hr})$, the plant will require about 220 round bails per day. For this study it was assumed that the plant would implement just-in-time stover delivery with 2 days of on-site storage. Recommended storage for round bales is that the bales are stacked 5 high in a pyramid formation as illustrated in Figure 4-5 (Schechinger et al., 1999). Therefore, 2 days of storage (440 bales) would require a minimum of $255 \mathrm{~m}^{2}\left(2,750 \mathrm{ft}^{2}\right)$ of storage area stacked approximately $7 \mathrm{~m}(23 \mathrm{ft})$ high.

Moisture control and ventilation must also be considered to reduce the risk of loss due to deterioration and fire. Should corn stover be selected as a fuel, additional storage considerations must be explored such as covered or indoor storage, drainage, rodent 
control, and moisture control. Alternative stover storage methods, such as ensiling in large concrete bunkers, are under development and may be considered in the future.

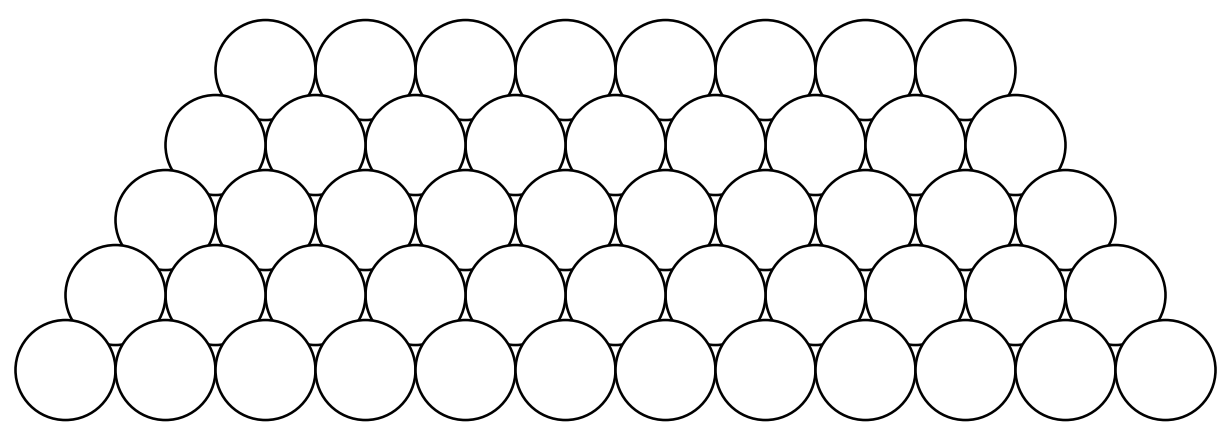

Figure 4-5. Recommended Round Bale Storage (Side View).

\subsubsection{Harvesting Equipment}

The majority of farmers that harvest corn do not have the necessary equipment for corn stover harvesting. Therefore, the power plant must either consider contracting with balers that have the necessary equipment or purchasing baling equipment and hiring operators to harvest the stover. Due to high equipment costs, operator training, and maintenance of baling equipment, it seems that contracting with balers may be the most economic alternative.

Presently, conventional harvesting systems do not treat the stover as a valuable commodity. It is left strewn on the ground and driven over by other equipment involved in the grain harvest. A whole stalk harvest system could improve the stover quality, reduce dirt contamination and lower the stover cost by collecting the stover in a one-step process and eliminating the need for wrapping or twining. New harvest systems are under development that should allow a substantial reduction in harvest cost of at least 50 percent per acre.

\subsubsection{Corn Stover Delivered Cost}

The study team conducted a market survey to determine the delivered cost of corn stover. Based on the literature (Schechinger et al., 1999) and information from current market sources, the study team estimates that facility might be expected to pay about $\$ 35 /$ wet tonne (\$31.8/ton) for delivered corn stover. This pricing is somewhat aggressive and will require diligence on the part of the project development team to ensure that it can be obtained. The economic model includes a high case sensitivity analysis at $\$ 50 /$ wet tonne ( $\$ 45.4 /$ ton). To simulate the effect of increased harvesting efficiency, a case was also examined at $\$ 20 /$ wet tonne $(\$ 18.1 /$ ton). Note that the delivered price includes a transportation component in the range of $\$ 5$ to $\$ 15 /$ tonne. 


\subsection{Oat Hulls}

Oat harvesting and processing in the Midwestern region make oat hulls an attractive alternative to corn stover as a candidate biomass fuel. Based on 2001 USDA agricultural data, Iowa produced about 9 million bushels of oats which is about 6 percent of US total. Not only is there an abundance of oats in the Midwestern region, but there are also numerous oat processing plants as well. These plants produce large quantities of oat hulls as a waste by-product. Unlike corn stover which is dispersed in fields and requires special harvesting, oat hulls are concentrated at oat processing plants. The study team contacted several Midwestern entities in the oat processing business to determine oat hull availability and market value.

\subsubsection{Oat Hull Fuel Properties}

Fuel properties have significant impacts on the technical and financial viability of biomass fueled power plants. Discussions of oat hull properties are outlined in the following subsections.

\subsubsection{Physical Properties}

When mature, the oat plant is about thirty six inches tall and has several stalks per plant as illustrated in Figure 4-6. There are normally up to four seeds per sheath, and the seeds hang on very fine, wiry stems. There are many seed sheaths per head, and the entire grain head can be up to eight or ten inches long. The oat seeds are covered with a hull, which is considered to be the oat hull as illustrated in Figure 4-7. Once the oats have been through the milling process the oat hull is removed as illustrated in Figure 4-8.

\subsubsection{Moisture Content}

Oat hulls have an obvious advantage over corn stover in that moisture content on an as received basis is approximately 9 percent, whereas corn stover moisture content ranges from 20 percent to 35 percent depending on stover harvesting conditions. To obtain lower moisture content for corn stover extended drying periods or thermal drying may be required. Since oat hulls are processed in a controlled environment, sheltered from rain and other environmental effects, moisture content of oat hulls is relatively simple to manage. The distribution of moisture in oat hulls is also relatively uniform, allowing the moisture content to be measured efficiently and accurately. Low moisture content in oat hulls ensures that there is lower tendency toward deterioration and better quality control. 


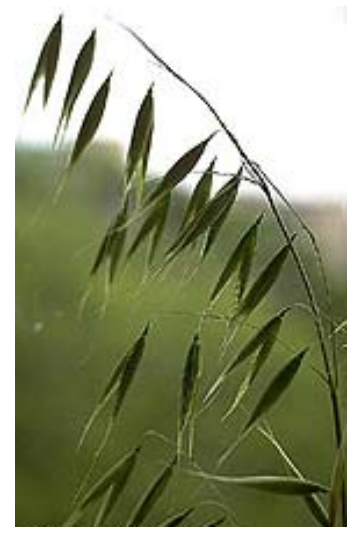

Figure 4-6. Oat Plant.

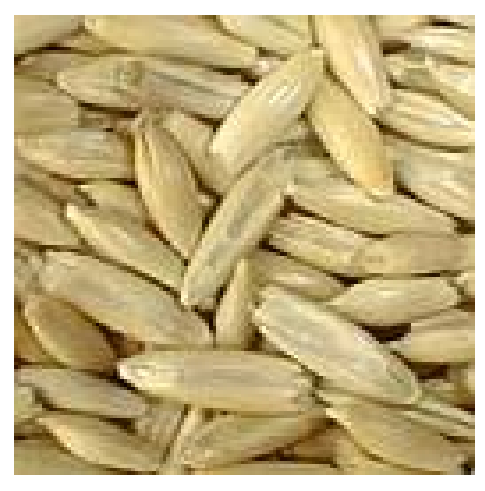

Figure 4-7. Oat Seeds with Hull.

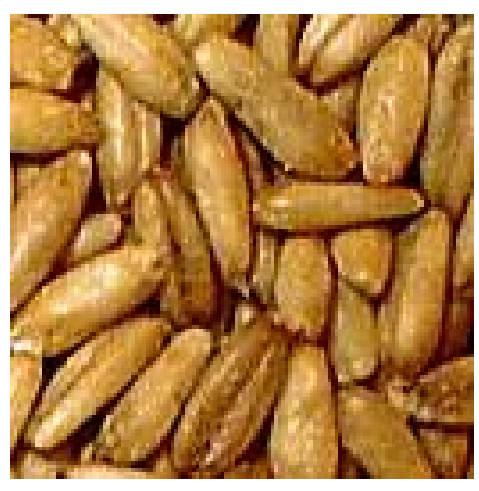

Figure 4-8.

Oat Seeds with Hull

Removed.

\subsubsection{Contaminants}

Contaminants are of much less concern in oat hulls than they are in corn stover, since they have had the majority of contaminants removed at the oat processing plant. Therefore, additional processing and cleaning equipment may not be needed for an oat hull fuel source.

\subsubsection{Chemical Properties}

Table 4-3 provides the chemical properties of oat hulls. For this report, the asfired (6.1 percent moisture) higher heating value of oat hulls is assumed to be 16,754 $\mathrm{kJ} / \mathrm{kg}(7,200 \mathrm{Btu} / \mathrm{lb})$. The lower heating value is $15,665 \mathrm{~kJ} / \mathrm{kg}(6,730 \mathrm{Btu} / \mathrm{lb})$. This is the same as the corn stover heating value.

Table 4-3 Ground Oat Hull Ultimate Analysis

\begin{tabular}{|l|c|c|}
\hline & As Received & Dry \\
\hline Moisture, percent & 9.56 & 0.00 \\
C, percent & 41.23 & 45.59 \\
H, percent & 5.35 & 5.914 \\
N, percent & 0.57 & 0.63 \\
S, percent & 0.05 & 0.05 \\
O, percent & 37.61 & 41.59 \\
Ash, percent & 5.63 & 6.23 \\
Heating Value, Btu/lb & 6,990 & 7,729 \\
\hline \multicolumn{2}{|l|}{ Source: Commercial Testing and Engineering CO. } \\
\hline
\end{tabular}




\subsubsection{Oat Hulls Fuel Availability}

Topics on oat hulls availability and requirements for the IPCC facility are explored in the following subsections.

\subsubsection{Oat Hull Availability and Market Value}

In order to determine the quantity of oat hulls available, several Midwestern oat processing plants and grain trading companies were contacted. The grain trading companies indicated that they could provide the facility with approximately 108 tonnes/week (15 tonnes/day) at an average of $\$ 50 /$ tonne delivered. The mills produced between 12 and 136 tonnes/day, and most would not disclose a price at this time. However, one of the mills indicated that it would be interested in meeting the biomass facility requirements by signing a long-term contract at an undelivered price of $\$ 31 /$ tonne. It may be possible to negotiate a lower rate.

Larger oat processing plants face greater disposal difficulties and were more likely to quote prices in the $\$ 25$ - 35/tonne range (not delivered). Smaller plants generally had short term contracts with local businesses and disposal is not a significant issue; they quoted between $\$ 40$ - 45/tonne. The study team also contacted LaBudde Group, a company out of Wisconsin that specializes in grain analysis and market pricing for grains and by-products. They suggested that the market price for oat hulls varied between $\$ 16$ - \$28/tonne. However, with a long term contract they believed that $\$ 22 /$ tonne was reasonable. Based on the preceding and the assumption that the pyrolysis plant will be near if not adjacent to a large oat hull processing facility, \$25/tonne was assumed for the base case economic model.

\subsubsection{Oat Hull Requirements}

At peak capacity the facility would need 129 tonnes (143 tons) of oat hulls per day. There are enough oat hulls available statewide to meet the facility's requirements; however, there are only two milling companies in the Midwestern region that can meet that demand entirely: Quaker Oats in Cedar Rapids and Con Agra in Sioux City. This demonstrates that the potential for oat hulls as a biomass resource is much smaller than corn stover. It may be advisable to locate the new power plant at one of these two facilities. Otherwise, a regional plant may need to be developed to collect the oat hulls from several sources. 


\subsubsection{Storage}

Storage of oat hulls is more straightforward than corn stover. Oat hulls are typically stored in grain silos so they do not encounter rain and other environmental effects that may result in degradation.

Two common types of grain silos are concrete and steel grain silos. Bridging is common with the storage of oat hulls. This is essentially the congregation of oat hulls that results in a bridge preventing the further filling or emptying of the silo. There is less bridging with a concrete structure since the concrete structure minimizes condensation build up. Storing oat hulls may require either a grain bin vibration system to keep the oat hulls from adhering to the walls of a steel silo or an auger system to prevent bridging.

Locating the new power plant at an oat mill may substantially reduce or eliminate the need for additional storage.

\subsubsection{Transportation}

Transportation costs are not an issue if the plant is located at an existing mill. However, if this is not possible, local contractors may be retained to transport the hulls. A survey was conducted to acquire information on the capacity of the local agricultural trucks, number of daily truckloads required to meet the facility's requirements, and the price per truckload. The capacity of the trucks varied with the type of truck. Hopper bottom trucks hold between 20 to 23 tonnes of ground oat hulls per load while the vans hold approximately 15 to 18 tons/load. To maintain operations, 129 tonnes/day (143 tons/day) would have to be shipped to the site. This corresponds to approximately 6 hopper truck loads/day. Trucking companies typically charge between $\$ 350$ to $\$ 500 /$ day for each of their trucks.

\subsection{Conclusions}

Both corn stover and oat hulls are suitable biomass fuels that are widely available in Iowa to support the IPCC power plant. However, our analysis indicates that oat hulls are more economical and technically feasible biomass fuel for the IPCC power plant for the following reasons:

- Oat hulls can be collected at a single source and involve only one contract. While corn stover would likely require the facility to contract with at least 40 different farmers.

- The moisture level in oat hulls (9 percent) is much less than corn stover (1830 percent) on an as received basis.

- Storage of oat hulls is much simpler utilizing grain silos, versus corn stover bales which require a much larger footprint and have a lower storage density. 
- The handling of oat hulls is also much simpler than corn stover which involves awkward bale stacking procedures, difficult moisture control, fire risk, the disposal of baling twine or plastic, etc.

- Oat hulls are a significantly cleaner fuel than corn stover requiring virtually no processing before pyrolysis.

- The delivered cost of oat hulls ( $\$ 25 /$ tonne) is lower than the cost of corn stover (\$35/tonne).

Nevertheless, the quantity of corn stover far exceeds oat hulls and stover collection and handling methods are being constantly improved. Though corn stover may not be the ideal source for biomass fuel at this time, it may be in the near future. 


\subsection{Economic Analysis}

An economic analysis was performed using the Black \& Veatch pro forma model to evaluate the economic viability of the proposed IPCC plant. The economic analysis considered two options for the IPCC project:

- Maximum Power Production Option - In this option the entire bio-oil output of the pyrolysis plant is used to fuel the combined power plant.

- Value-Added Chemicals Option - In this option, value-added chemicals are extracted from the bio-oil resulting in lower flow of bio-oil to the power cycle.

For each option, the pro forma evaluated a base case (most likely) scenario and a number of sensitivity scenarios based on the two types of biomass fuels; corn stover and oat hulls.

\subsection{Pro Forma Overview}

The pro forma determines the project return on investment, as measured by the project net present value (NPV) and the internal rate of return (IRR).

The NPV determines whether the financial returns will be high enough to justify the project. In the pro forma analysis, NPV is calculated by discounting the after-tax cash inflows to the beginning of the operating period and then subtracting the corresponding future value of the equity investment. If the difference is greater than zero, the project is acceptable, whereas a negative NPV would mean that the project is not acceptable at the chosen discount rate.

The IRR is the discount rate at which NPV is zero. An IRR higher than the chosen discount rate (or minimum equity return) indicates the project is acceptable.

\subsection{Base Case Assumptions}

The economic analysis for the base case maximum power production scenario is based on the study assumptions listed in Table 5-1. 
Table 5-1. Economic Analysis Assumptions (2003 \$US)

\section{Financial assumptions}

Construction period, months

Start date of commercial operation January 2005

Discount rate (minimum equity return), percent 12

Inflation rate, percent

Debt to equity ratio $50 / 50$

Project term, years

Interest rate on long term debt, percent

Effective tax rate, percent

30

Depreciation method

7-year, double declining balance

\section{Project revenues}

Average electric sales rate, $\$ / \mathrm{MWh} \quad 30$

Capacity credit, $\$ / \mathrm{kW}-\mathrm{yr} \quad 24$

Char sales rate, $\$ / G J$

Renewable energy credit, $\$ / \mathrm{MWh}$

Anhydrosugar value, $\$ / \mathrm{kg}$

\section{Power production and consumption}

Net combined cycle power block output, $\mathrm{kW}$

1.00

Annual combined cycle power production, GWh/yr

Pyrolysis plant power consumption, $\mathrm{kW}$

Annual pyrolysis plant power consumption, GWh/yr

\section{Fuel information}

Biomass fuel feed rate, tonne/hr

Oat hulls delivered cost, \$/wet ton

Corn stover delivered cost, \$/wet ton

Ash disposal cost, \$/ton

Supplemental natural gas consumption, MBtu/yr

0 (Land Applied)

Supplemental natural gas price, \$/MBtu

43,748

Operating profile

Operating mode 3.50

Pyrolysis plant capacity factor, percent

Base Load

Combined cycle capacity factor, percent

90.4

Operating and maintenance cost

Oat hulls O\&M cost, \$/yr

80.0

Corn stover O\&M cost, $\$ / y r$

$1,518,778$

Total project cost, $\$$

$1,678,778$

$18,392,770$

The following changes are made to the base case assumptions for the value-added chemicals option: 
- Recover $20 \%$ of the bio-oil yield as anhydrosugar (5.8 million $\mathrm{kg} / \mathrm{yr}$ )

- Add anhydrosugar sales revenue of $\$ 1 / \mathrm{kg}$

- Reduce capacity factor of the combined cycle plant by $20 \%$ (from $80 \%$ to $64 \%)$

- Raise the power sales price to $\$ 35 / \mathrm{MWh}$ (from $\$ 30 / \mathrm{MWh}$ ) due to the few operating hours

- Increase capital and operating costs (see the following sections)

\subsubsection{Capital Costs}

A total project capital cost estimate was prepared based on inputs from the various team members, vendor quotes, and historical construction industry data. This estimate is indicative in nature ( $+/-30$ percent) and will vary based upon the final system design. The cost estimate includes direct and indirect costs for design, equipment procurement and construction. Table 5-2 shows the estimate summary. It was determined that at this level of accuracy, the cost estimate for the oat hull and corn stover plants could be assumed to be the same.

\section{Table 5-2. Capital Cost Estimate (2003 US\$).}

\section{Maximum Power Production Option}

Turnkey Pyrolysis Plant

Combined Cycle Plant

Combustion Turbine Generators

Steam Turbine Generator

Heat Recovery Steam Generator

Combined Cycle Balance of Plant

Combined Cycle Installation

Subtotal Combined Cycle

IPCC Balance of Plant Equipment and Construction Indirect Expenses

Total Maximum Power Production Project Cost

Incremental Equipment for Value-added Chemicals

Biomass Pretreatment System

Fractionating Quencher

Subtotal Incremental Costs

Total Value-added Chemical Project Cost

Note: Estimated capital cost is the same for both oat hull and corn stover fuels.

The proposed IPCC system is estimated to have a total project cost of $\$ 18.4$ million, which, based on a net combined cycle output of $7,655 \mathrm{~kW}$, is equal to 
$\$ 2,400 / \mathrm{kW}$. This cost does not include the additional equipment required for production of value-added chemicals. This additional equipment is estimated to cost $\$ 1.3$ million. The IPCC capital cost compares favorably to conventional biomass power systems in this size range, which cost around $\$ 2,000$ for "bare-bones" systems to over $\$ 3,000 / \mathrm{kW}$ for systems designed for higher efficiency and reliability.

Because this is a first-of-a-kind facility, a certain amount of uncertainty in capital costs should be reasonably expected. Based on the indicative accuracy level (+/- 30 percent), the capital cost for the maximum power production option may vary from $\$ 12.9$ million to $\$ 23.9$ million. An investigation of the sensitivity of the project to capital cost variation is included later in this section.

\subsubsection{Operating and Maintenance Costs}

Operating and maintenance (O\&M) costs are defined as all expenses associated with the processing of the biomass feedstock and production of the char, bio-oil, and electricity. O\&M costs typically include production and maintenance labor, chemical costs, water costs, waste disposal costs, maintenance parts and materials, and various other expenses associated with plant operation and maintenance. Not included in O\&M costs are items such as fixed charges on capital investment which consist of return on investment, depreciation, and income tax.

Operation and maintenance costs are typically separated into two components: fixed costs and variable costs. The fixed component of O\&M costs consists primarily of the wages and wage-related overheads for the permanent plant staff of operators, maintenance personnel, and supervisory personnel. These costs are classified as fixed because the expense for normal straight-time work is incurred whether or not the plant is operating. Conversely, the variable component of O\&M costs includes expenses such as chemicals, electric power, maintenance parts and materials, and consumables, all of which are directly influenced by the amount of plant operation.

Even though the plant will be largely automated, by far the largest O\&M cost for the maximum power production option is personnel. For oat hulls, it is estimated that a total of six people operating on four shifts could operate the plant continuously. Corn stover will likely require additional fuel handling personnel, and a staff size of eight is estimated. Including staff costs and other miscellaneous O\&M expenses, the total estimated annual O\&M cost is about $\$ 1.5$ million and $\$ 1.7$ million for oat hulls and corn stover, respectively. These estimates are equivalent to about $\$ 30 / \mathrm{MWh}$, which is comparable to O\&M costs for other power plants in this size range. A breakdown of this estimate and estimates for the value-added chemicals option are provided in Table 5-3. The additional O\&M costs for production of value-added chemicals are very large, $\$ 3.3$ 
million extra per year. However, there is a proportionate increase in projected revenues from anhydrosugar sales.

Table 5-3. Operating and Maintenance Cost Estimate (2003 US\$).

\begin{tabular}{|l|r|r|}
\hline \hline & Oat Hulls & Corn Stover \\
\hline Maximum Power Production Option & 480,000 & 640,000 \\
Overall Plant Labor & 288,000 & 288,000 \\
Other Overall Fixed O\&M Costs (non-labor) & & \\
Pyrolysis Plant & 67,847 & 67,847 \\
$\quad$ Consumables \& Services & 261,406 & 261,406 \\
$\quad$ Maintenance & 153,118 & 153,118 \\
$\quad$ Supplemental Natural Gas Consumption & 268,406 & \\
Combined Cycle Plant & $\underline{\text { incl. above }}$ & $\underline{\underline{\text { incl. above }}}$ \\
$\quad$ Variable O\&M Expenses & $\mathbf{1 , 5 1 8 , 7 7 8}$ & $\mathbf{1 , 6 7 8 , 7 7 8}$ \\
$\quad$ Fixed O\&M Expenses & & \\
Total Maximum Power Production O\&M Cost & $2,300,000$ & $2,300,000$ \\
Incremental O\&M Costs for Value-added Chemicals & $\underline{1,000,000}$ & $\underline{1,000,000}$ \\
$\quad$ Biomass Pretreatment System & $\underline{3,300,000}$ & $\underline{\underline{3,300,000}}$ \\
Fractionating Quencher & $\mathbf{4 , 8 1 8 , 7 7 8}$ & $\mathbf{4 , 9 7 8 , 7 7 8}$ \\
$\quad$ Subtotal Incremental Costs &
\end{tabular}

\subsection{Renewable Energy Credits}

An additional and important consideration for this project is evaluation of renewable energy credits. The use of biomass for electricity generation may qualify for renewable energy incentives, green power sales, greenhouse gas emission credits, or other economic credits associated with renewable power. These are sometimes referred to as "Green Tags," "Renewable Energy Certificates," or "Tradable Renewable Credits". The emergence of renewable portfolio standards in various states (and perhaps on a national level) will support development of larger markets for trading these credits.

The base case assumptions do not assign any premium economic value for the renewable energy produced by the biomass plant. The green premium represents incremental costs above the indicated power sales prices $(\$ 30 / \mathrm{MWh})$. This premium, the value of which is captured in "renewable energy credits," may be marketed to retail customers, wholesale customers, or used to offset purchases of renewable energy that might be made from other power/credit suppliers. The green premium might also reflect the value of tax credits for renewable power generation. Currently there is a $\$ 18 / \mathrm{MWh}$ federal production tax credit available for wind projects. The tax credit is also available 
to biomass power produced from energy crops or poultry litter. There are current proposals in Congress to expand this credit to other biomass fuels, including those evalauted for this project.

As discussed in the next section, because there is no value assigned to the renewable attributes of the biomass power in the base case, most of the base case economic results are negative. The economic model was used to calculate the renewable energy credit value (breakeven value) for which the IRR equals the minimum equity return (the discount rate, 12 percent).

\subsection{Base Case Results}

Table 5-4 summarizes the results of the four scenarios investigated. These results are discussed further below. Appendix B includes an example pro forma model.

\begin{tabular}{|c|c|c|}
\hline & Oat hulls & Corn Stover \\
\hline \multicolumn{3}{|l|}{ Internal Rate of Return } \\
\hline Maximum Power Production Option & NA & NA \\
\hline Value-added Chemicals Option & $5.46 \%$ & $-1.58 \%$ \\
\hline \multicolumn{3}{|c|}{ Renewable Energy Premium Required to Meet Minimum Equity Return (12\%) } \\
\hline Maximum Power Production Option & $\$ 55.13 / \mathrm{MWh}$ & $\$ 66.15 / \mathrm{MWh}$ \\
\hline Value-added Chemicals Option & $\$ 17.99 / \mathrm{MWh}$ & $\$ 31.75 / \mathrm{MWh}$ \\
\hline
\end{tabular}

\subsubsection{Maximum Power Production Option}

For power production only, the base case economic model does not result in a positive internal rate of return (IRR). In other words, the project does not economically appear viable under the base case assumptions. These assumptions are based on dispatching the plant in a large utility system with relatively low power costs $(\$ 30 / \mathrm{MWh}$ energy, and $\$ 24 / \mathrm{kW}$-yr capacity). This scenario demonstrates how the IPCC plant would compete against traditional open-market utility coal, hydro, and gas resources, without considering any of the external benefits of biomass power.

The base case scenario does not include any credits for the renewable energy aspects of the plant. The model was used to calculate the "breakeven" incremental renewable energy credit $(\$ / M W h)$ for which the IRR equals the discount rate (12 percent). Based on the model results, the breakeven credit value is $\$ 55.13 / \mathrm{MWh}$ for oat hulls and $\$ 66.15 / \mathrm{MWh}$ for corn stover. These credits are in addition to the $\$ 30 / \mathrm{MWh}$ power sales rate; therefore the total breakeven power sales rate would be $\$ 85.13 / \mathrm{MWh}$ 
for oat hulls and $\$ 96.15 / \mathrm{MWh}$ for corn stover. Power generated by most traditional biomass power plants is $\$ 70$ to $\$ 100 / \mathrm{MWh}$. Thus, although the maximum power option would not likely be competitive with traditional wholesale utility assets, it appears to be competitive with other biomass options. Considering that this study characterized a small first-of-a-kind facility and that future plants will likely have improved economics, additional investigation is recommended.

\subsubsection{Value-Added Chemical Option}

Value-added chemical production greatly improves the economics of the project. Including a value of $\$ 1 / \mathrm{kg}$ for anhydrosugar in the base case economic assumptions indicates that the project may be viable in the base case, with a positive IRR of 5.46 percent for oat hulls. To obtain the minimum equity return (12\%), a renewable energy credit of $\$ 18 / \mathrm{MWh}$ (equal to the current production tax credit) would be needed for oat hulls, and \$31/MWh would be needed for corn stover. Because of the potential benefit of value-added chemical production, it is recommended that this alternative be investigated further.

\subsection{Sensitivity Cases}

The economic analysis evaluated a number of sensitivity cases to assess the impacts of key variables on the project economic viability. Key variables that were considered in the sensitivity analysis include:

- Capital cost

- Operating and maintenance cost

- Fuel cost

- Anhydrosugar value

For ease of comparison, the incremental renewable energy credit necessary to obtain minimum equity return is used as the economic metric. The following charts show sample results of the sensitivity investigations. 


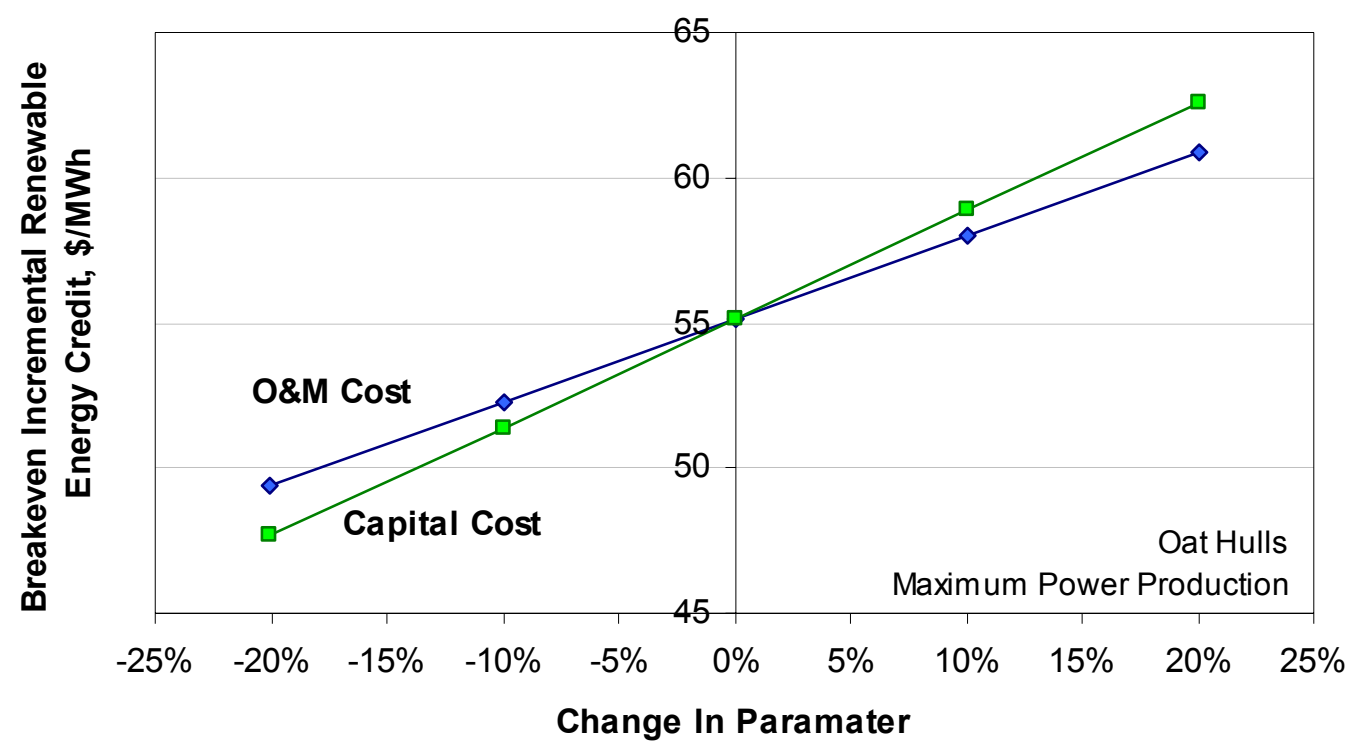

Figure 5-1. O\&M and Capital Cost Sensitivity Investigations.

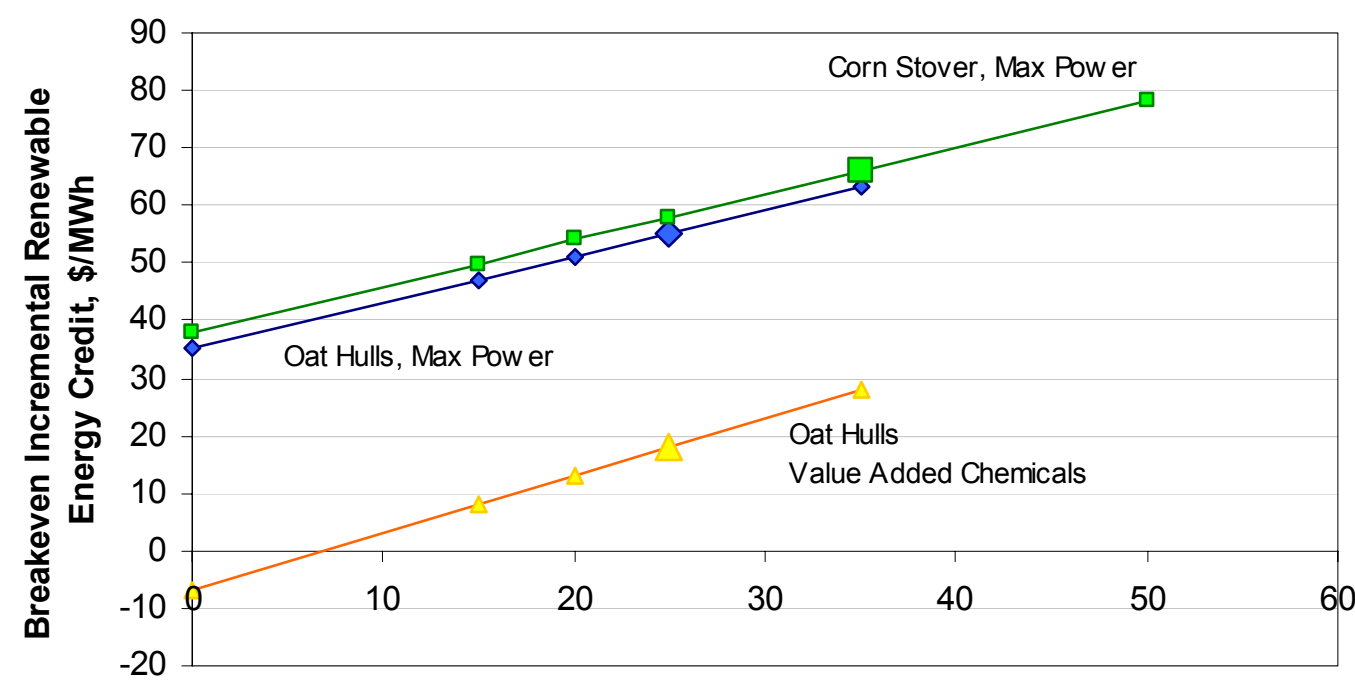

Biomass Cost, \$/wet ton delivered

Figure 5-2. Biomass Cost Sensitivity Investigations. 


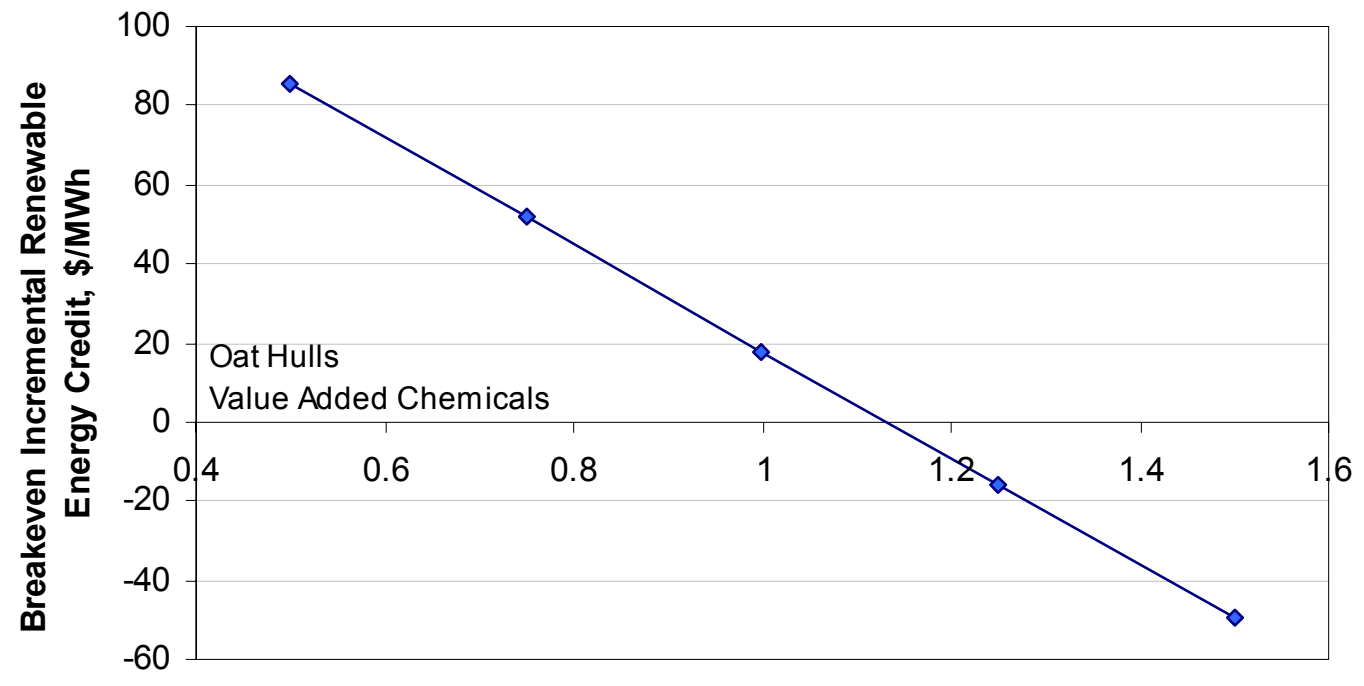

Anhydrosugar Value, $\$ / k g$

Figure 5-3. Anhydrosugar Sensitivity Investigation. 


\subsection{Benefits}

The proposed project has the ability to address multiple national benefits (power, heat, byproducts; rural development; environmental quality; greenhouse gas emissions; economic benefits; infrastructure and fuel supply benefits and impacts). These are discussed further in this section.

\subsection{Power, Heat, and Byproducts}

The proposed integrated pyrolysis combined cycle converts 5.39 tonne/hr of biomass into $7.66 \mathrm{MW}$ of electric power at 37.5 percent net combined cycle efficiency. Byproducts include 1.1 tonne/hr of char could be upgraded to activated carbon, and up to $742 \mathrm{~kg} / \mathrm{hr}$ of highly valuable anhydrosugar levoglucosan.

The major differentiator between the proposed IPCC power system and conventional biomass power systems is efficiency. Efficiency is low for small conventional biomass power systems, typically around 15 percent, and rarely exceeding 20 percent. By comparison, the net combined cycle efficiency for this process is estimated to be 37.5 percent, and the average total fuel cycle efficiency is estimated to be 22.2 percent. The flexibility of not having to co-locate the pyrolysis plant with the power plant also potentially improves project economics. The bio-oil could be generated at numerous distributed pyrolysis plants located near biomass resource concentrations. The oil could then be transferred to a large central biopower facility (perhaps $100 \mathrm{MW}$ or more) and utilized in state-of-the art combined cycle technologies with efficiencies of over 50 percent. The bio-oil would also be a suitable cofiring fuel for existing coal plants, with minimal retrofit costs necessary to cofire the fuel.

\subsection{Rural Development Benefits}

The proposed power system provides high thermodynamic efficiency at a scale suitable for many small communities $(<10 \mathrm{MWe})$. The fuel demand (129 tpd) can be provided locally. For example, a plant fueled with corn stover (assuming only one-half of the stover was removed from the field) would require collection of stover from about 12,000 hectares (30,000 acres) to support the annual fuel requirements. In Iowa, about 85 farms would be needed on average to support the project. Anecdotal evidence from a commercial corn stover harvesting and storage operation in western Iowa suggests that net income for farmers doubled on acreage for which they received $\$ 16 /$ ton of corn stover collected by a custom harvester (Olson, 2001).

In the United States, most states are net importers of energy. For example, the state of Iowa imports over $90 \%$ of its energy, which represents billions of dollars 
annually. Many Midwestern states have sufficient agricultural base to generate a significant amount of their energy requirements without impacting their ability to provide food, feed, and fiber in the current U.S. economy. For example, the state of Iowa alone could provide $4.3 \times 10^{5}$ terajoules $\left(4.06 \times 10^{14} \mathrm{Btu}\right)$ of biomass energy without appropriating any cropland presently used for food, feed, or fiber production (Brown, 1994). This is enough resource to fuel over 600 of the biomass power plants proposed here.

\subsection{Environmental Quality and Greenhouse Gas Emissions}

Environmental benefits are strongly dependent on the kind of fuel and conversion process the proposed power plant replaces. Compared to coal, the most common power generation fuel, the proposed plant would provide excellent environmental benefits. Reductions would be made in various pollutants. Biomass fuels contain little sulfur compared to coal, resulting in decreased production of sulfur dioxide. Toxic metals, such as mercury, cadmium, and lead, will also be reduced because of the substitution of biomass for coal. The proposed power cycle is designed to minimize emissions of particulates, and it will use combustion turbine power generation to substantially reduce nitrogen oxide emissions compared to coal.

Increasing energy efficiency and reducing dependence on fossil fuels with renewable energy are two of the leading options for reducing emissions of carbon dioxide $\left(\mathrm{CO}_{2}\right)$, the principal greenhouse gas. Fossil-based power generation accounts for thirtyfive percent of the anthropogenic $\mathrm{CO}_{2}$ emission in the U.S. Biomass power is viewed as a carbon-neutral power generation option. While carbon dioxide is emitted during biomass combustion, an equal amount of carbon dioxide is absorbed from the atmosphere during the biomass growth phase. Thus, biomass fuels "recycle" atmospheric carbon, minimizing global warming impacts. The overall net effect of adding the IPCC project will be a net reduction of $\mathrm{CO}_{2}$ emissions.

\subsection{Project Sustainability and Opportunities for Replication}

Sustainability of the proposed project is strongly dependent on fast changing political and regulatory factors in the United States. Without subsidy, dedicated energy crops, such as switchgrass, cost about \$3/MMBtu. In contrast, Powder River Basin coal is delivered to Iowa at less than $\$ 1 /$ MMBtu. Concerns about sulfur, mercury, and carbon dioxide emissions from coal-fired plants may eventually lead to regulatory changes that improve the attractiveness of biomass for power generation. Improvements in production and harvesting practices are also expected to improve the economics of this feedstock. However, at present, the sustainability of the proposed biomass power plant depends on 
exploitation of niche markets associated with agricultural residues, such as corn stover, and agricultural processing wastes, such as oat hulls. Opportunities for early replication will be dependent on local factors of power demand and waste resource availability.

\subsection{Economic Benefits}

Properly configured, the proposed IPCC project represents a good opportunity for investors with attractive economic benefits. The proposed IPCC system is estimated to have a total project cost of $\$ 18.4$ million, which, based on a net combined cycle output of $7,655 \mathrm{~kW}$, is equal to $\$ 2,400 / \mathrm{kW}$. For a small amount of additional capital, recovery of valuable chemicals may also be performed. The IPCC capital cost compares favorably to conventional biomass power systems in this size range, which cost around $\$ 2,000$ for "bare-bones" systems to over $\$ 3,000 / \mathrm{kW}$ for systems designed for higher efficiency and reliability.

The economic analysis showed that at electricity sales prices of $\$ 30 / \mathrm{MWh}$, the maximum power option would not be competitive with traditional utility assets; however, this configuration appears to be competitive with other biomass options. Value-added chemical production greatly improves the economics of the project. To obtain the minimum equity return (12\%), a renewable energy credit of only $\$ 18 / \mathrm{MWh}$ (equal to the current production tax credit) would be needed for oat hulls. Considering that this study characterized a small first-of-a-kind facility and that future plants will likely have even better economics, additional investigation is recommended.

This technology may be an excellent match for on-site heat and power generation at facilities with a ready supply of waste biomass. The electricity produced would directly offset retail rates (as opposed to having to compete against low wholesale power costs). The combination of lower fuel cost, power cost savings, and recovery of process waste heat for steam generation would greatly enhance economics. 


\section{References}

A. Bridgewater et al., "The Production of Chemicals from Fast Pyrolysis Bio-oils, Desmond Radlein, RTI, in "Fast Pyrolysis of Biomass: A Handbook," CPL Press, 1999.

Agblevor, F. A., Besler, S., Montagne, D., and Evans, R. J. (1995) "Influence of inorganic compounds on char formation and quality of fast pyrolysis oils," ACS 209th National Meeting, Anaheim, CA.

Blazej, A. and Kosik, M., "Environmentally acceptable conversion technology for the biochemical utilization of lignocellulosics", in Cellulosics: Pulp, Fibre and Environmental Aspects, J.F. Kennedy, G.O. Phillips and P.A. Williams (eds.), Ellis Horwood, NY, 1993, pp355-364.

Bridgwater, A. V. et al. (1999) Fast Pyrolysis of Biomass: A Handbook, CPL Press, Newbury, United Kingdom.

Brown, R.C., Colletti, J., Hallam, A., "Factors Influencing the Adoption of Biomass Energy Systems: An Evaluation for Iowa", Iowa State University.

Brown, R. C., Smeenk, J., and Wistrom, C., "Design of a moving bed granular filter for biomass gasification," Proceedings of the Progress in Thermochemical Biomass Conversion Conference, Tyrol, Austria, September 17-22, 2000.

Colver, G., Brown, R. C., Shi, H., and Soo, S., "Improving efficiency of a counter-current flow moving bed granular filter," Fifth International Symposium on Gas Cleaning at High Temperature, Morgantown, West Virginia, September 18-20, 2002.

Correspondence from J. Piskorz, Experimental results, May 31, 1999

D. Fuleki, C. P. Patnaik, and R Thampuraj, "Gas Turbine Operation using Biomass Derived Pyrolysis Fuel," Orenda Aerospace Corporation, 2000

Dayton, D.C., Jenkins, B.M., Turn, S.Q., Bakker, R.R, Williams, R.B., Belle-Oudry, D. and Hill, L.M. (1999) "Release of inorganic constituents from leached biomass during thermal conversion," Energy and Fuel 13(4), pp. 860-870. 
Diebold, J. P., Scahill, J. W., Czernik, S., Phillips, S.D., and Feik, C. J. (1996) "Progress in the production of hot gas filtered bio-crude oil at NREL," Proceedings of the 2nd EU/Canada Workshop on Thermal Biomass Processing, CPL press, Newberry, United Kingdom.

"DynaMotive's BioOil Successfully Replaces Natural Gas in Industrial Lumber Dry Kiln” DynaMotive Press Release Sept. 23, (2002)

Elliot, D. C. (1994) "Water, alkali, and char in flash pyrolysis oils," Biomass Bioenergy 7, 179-186.

Environment Canada , "The Greenhouse Gas Emissions Outlook to 2020", http://www.ec.gc.ca/climate/fact/greenhou.html, Global Climate Change, Nov. 1997.

Gabra and Kjellstrom, Orenda Correspondence, High efficiency combined cycle gas turbine power production from bagasse for a Tanzanian Sugar Mill, 2002

Garside, J. (1994) Separation Technology: The Next Ten Years, Inst. Chem. Eng., London.

Guthrie, K. M. (1969) "Data and techniques for preliminary capital cost estimating, " Chem. Eng., pp. 114-142, March 24.

International Energy Agency statistics on world CO2 emissions, http://www.iea.org/stats/files/keystats/stats_98.htm, 1996.

Iowa Department of Natural Resources. "Biomass Other." . 5 Mar. 2002

$<$ http://soybean.agronomy.wisc.edu/publications/92_equiv_weights_aa.htm $>$.

J. Yan, P. Alvors, L. Eidensten and G. Svedberg, "A future for biomass”, Mechanical Engineering, Vol. 119/No. 10, Oct. 1997, pp. 94-96.

Johnson, W.L. "BioOil from Bagasse", 3rd Annual World Sugar Co-Products Conference, Bangkok, Thailand, October 7-8, 2002.

Johnson, W., Yavari, G., Radlein, D., "Scale-up of the BioTherm Fluidized Bed Fast Pyrolysis Process", Canadian Society of Chemical Engineers Annual Conference, Vancouver, BC, Canada, October, 2002. 
Katritzky, A.R., Allin, S.M. and Siskin, M., "Aquathermolysis: Reactions of Organic Compounds with Superheated Water", Acc. Chem. Rews., 29, 399-406, 1996.

Kitamura, Y., Abe, Y. and Yasui, T. "Metabolism of levoglucosan (1,6-Anhydro- -Dglucopyranose) in Microorganisms”, Agric. Biol. Chem., 55, 515-521, 1991.

K.W. Morris, "BioThermTM: A System for Continuous Quality, Fast Pyrolysis BioOil," 4th Biomass Conference of the Americas 1999.

Ménard, H., Grisé, M., Martel, A., Roy, C. and Bélanger, D., "Saccharification de la biomasse par pyrolyse à pression réduite suivie d'une hydrolyse", 5'th Canadian R\&D Seminar, S. Hasnain (ed.), Elsevier App. Sci. Publishers, London, 1984.

Morris, K.W., Johnson, W.L., Thambraj, R., "Fasts Pyrolysis of Biomass for Green Power Generation", 1st World Conference and Exhibition on Biomass for Energy and Industry, Seville, Spain, June 5-9, 2000.

Nakahara, K., Kitamura, Y., Yamagishi, Y. and Shoun, H., "Levoglucosan Dehydrogenase Involved in the Assimilation of Levoglucosan in Arthrobacter sp. I-552", Biosci. Biotech. Biochem., 58, 2193-2196, 1994.

Oasmaa, A. and Peacocke, C. "A guide to physical property characterization of biomassderived fast pyrolysis liquids", VTT Publication 450, Espoo, Finalnd, 2001.

P. Gogolek and F. Preto, "Status and Potential of Energy from Biomass in Canada", Proceedings of Combustion and Global Climate Change, Combustion Canada, May 1999.

Piskorz et al., United States Patent No. 5,728,271 "Energy Efficient Liquefaction of Biomaterials by Thermolysis."

Prosen, E.M., Radlein, D., Piskorz, J., Scott, D.S. and Legge, R.L. "Microbial Utilization of Levoglucosan in Wood Pyrolysate as a Carbon and Energy Source", Biotechnol. and Bioengineering, 42, 538-541, 1993.

Radlein, D., "Study of Levoglucosan Production. A Review", Final Report, Natural Resources Canada, March, 2000, PWGSC Contract No. 23348-8-3247/001/SQ.

R. G. Andrews, D. Fuleki, S. Zukowski and P.C. Patnaik, "Results of Industrial Gas Turbine Tests Using a Biomass Derived Fuel", Proceedings of the Third Biomass Conference of the Americas, pp. 425-436, August 1997. 
S. Czernik, "Storage of Biomass Pyrolysis Liquids", Proceedings of the Biomass Pyrolysis Oil Properties and Combustion Meeting, NREL/CP-430-7215, pp. 67-73, 1994

Saxena, S. C. et al. (1985) Particulate removal from high temperature, high pressure combustion gases, Prog. Energy Combust. Sci. 11, 193-251.

Schuchardt, W., Ger. 738,962, July 29, 1943.

Scott, D. S., Majerski, P., Piskorz, J., and Radlein, D.(1999) A second look at fast pyrolysis of biomass - the RTI process," J. Analytical and Applied Pyrolysis 51, 23-37.

Ulrich, G.D. 1984. A Guide to Chemical Engineering Process Design and Economics, New York: Wiley.

Schechinger, T.M., Hettenhaus, J., "Corn Stover Harvest: Grower, Custom Operator, and Processor Issues, and Answers”, September 30, 1999.

Stein, S.E. and Brown, R.L., "Estimation of normal boiling points from group contributions “, Journal of Chemical Information and Computer Science, Volume 34, pp. 581-7 (1994).

Suuberg, E., et al (Twenty-Sixth International Symposium on Combustion, 1996.

Turn, S.Q., Kinoshita, C.M., and Ishimura, D.M. (1997) "Removal of inorganic constituents of biomass feedstocks by mechanical dewatering and leaching," Biomass and Bioenergy. 12(4), pp. 241-252.

United Nations Development Program - Global Environment Facility, Climate Change Information Kit, http://www.undp.org/gef/new/ccinfo.htm, updated July 1999.

University of Wisconsin Madison. "Equivalent Weights of Grain at Various Moisture Levels." 3 Mar. 2002

$<\mathrm{http}$ //soybean.agronomy.wisc.edu/publications/92_equiv_weights_aa.htm $>$. 


\section{List of Acronyms and Abbreviations}

\begin{tabular}{|c|c|}
\hline B & bio-oil \\
\hline $\mathrm{BCO}$ & bio-crude oil \\
\hline $\mathrm{C}$ & cellobiosan \\
\hline $\mathrm{CBM}$ & bare module cost \\
\hline $\mathrm{CCF}$ & contingency and fee \\
\hline $\mathrm{CC}$ & combined cycle \\
\hline $\mathrm{CD}$ & total direct cost \\
\hline $\mathrm{CE}$ & engineering expenses \\
\hline CFIT & total cost of freight, insurance, and taxes \\
\hline CID & total indirect cost \\
\hline $\mathrm{CL}$ & direct labor cost \\
\hline $\mathrm{CM}$ & materials for installation cost \\
\hline $\mathrm{CO}$ & construction overhead \\
\hline $\mathrm{CP}$ & equipment (f.o.b) cost \\
\hline CRP & Conservation Reserve Program \\
\hline CTM & total module cost \\
\hline$\Delta \mathrm{H}$ & magnitude of heat transfer operations \\
\hline DSCR & debt service coverage ratio \\
\hline DWCorn & dry weight of corn per bushel \\
\hline EPI & Energy Product of Idaho \\
\hline EWCorn & estimated weight of corn per bushel at moisture content $M$ \\
\hline f.o.b & Free on Board \\
\hline $\mathrm{Fe}$ & iron \\
\hline $\mathrm{G}$ & volatiles comprise gas \\
\hline $\mathrm{H}$ & heavy \\
\hline $\mathrm{HEC}$ & herbaceous energy crops \\
\hline HFCS & high fructose corn syrups \\
\hline IGCC & integrated gasification combined cycle \\
\hline IHCF & Iron Horse Custom Farms \\
\hline IPCC & integrated pyrolysis combined cycle \\
\hline IRR & internal rate of return \\
\hline $\mathrm{L}$ & light \\
\hline $\mathrm{LCC}$ & Land Capability Classification \\
\hline LG & levoglucosan \\
\hline LMF & labor module cost \\
\hline
\end{tabular}




$\begin{array}{ll}\text { M } & \text { moisture content of the corn } \\ \text { MBGF } & \text { moving bed granular filter } \\ \text { MMF } & \text { material module factors } \\ \text { NPV } & \text { net present value } \\ \text { O } & \text { organics } \\ \text { O\&M } & \text { operation and maintenance } \\ \text { PL } & \text { pyrolytic lignin } \\ \text { SRWC } & \text { short-rotation woody crops } \\ \text { Std 1 } & \text { measured intensity standard } \\ \text { V } & \text { volatiles } \\ \text { W } & \text { water } \\ \text { WE } & \text { water extraction } \\ \text { WRP } & \text { Wetlands Reserve Program }\end{array}$




\section{Appendix A. Fractionating Condenser Cost Estimation Approach}

A simplified fractionating column will be used for cost estimation purposes as shown below:

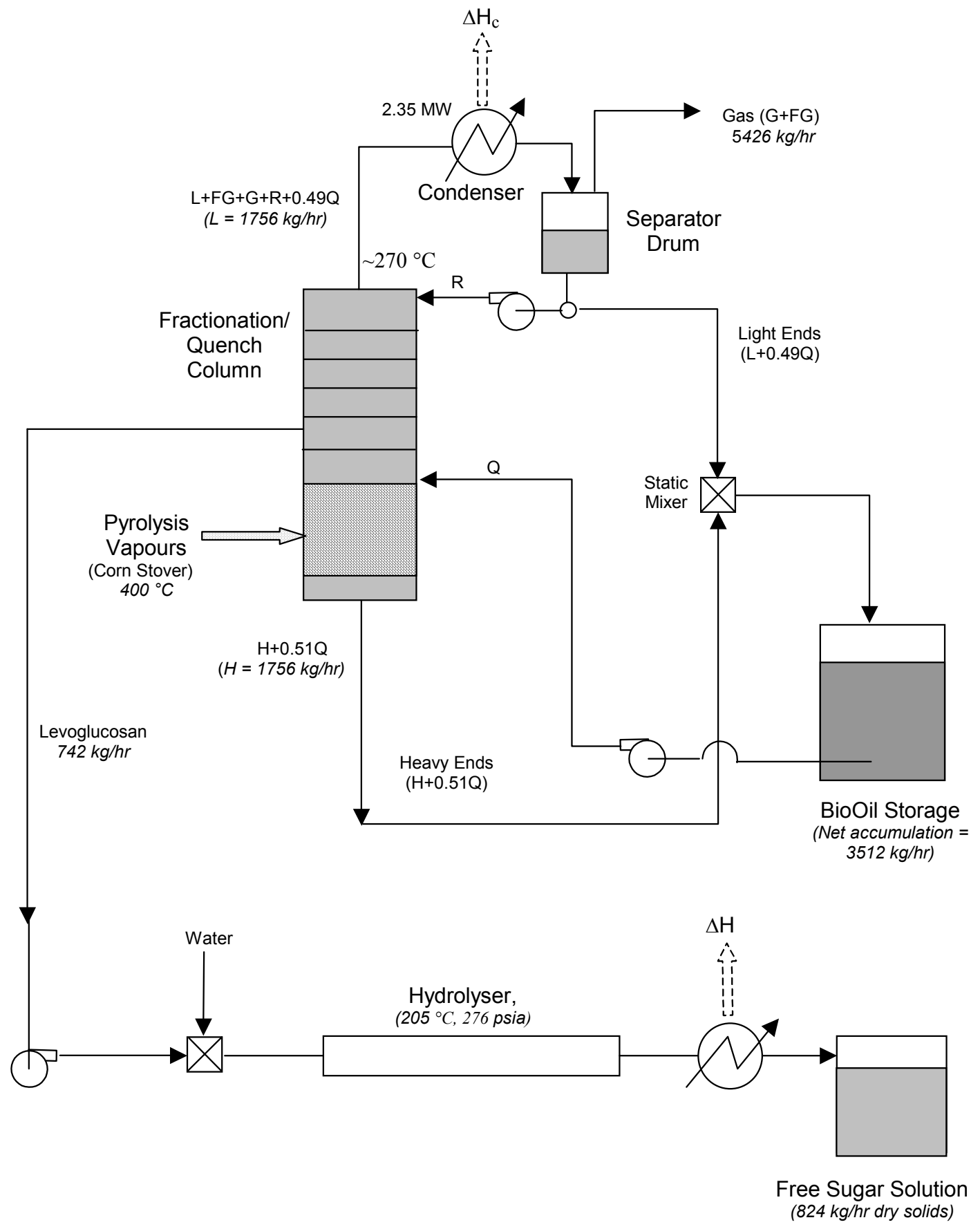




\section{Assumptions:}

- Only levoglucosan is recovered. (Though for a relatively small incremental cost other chemicals could be recovered as well, e.g. acetic acid, phenols.)

- Furthermore, no attempt is made to extract the higher molecular weight, oligomeric, anhydrosugars from the heavy ends.

- Levoglucosan is recovered solely for the purpose of conversion to fermentable sugars.

- The hot levoglucosan is hydrolysed by combining with fresh water and pumping the resulting solution through a tubular reactor at about $205^{\circ} \mathrm{C}$. The resulting sugar solution requires no further treatment before sending for fermentation.

- Heat is recovered only from the overhead condenser.

- The condensing heat exchanger on the exit stream can be a basic shell and tube type since removal of the bottoms containing the heavy tars (pyrolytic lignin) removes the fouling problems they normally cause.

- The system is intended to replace all of the current biooil quench and condensation train. (The biooil storage tank is not included.)

- We use methods from Guthrie (Chemical Engineering, March, 1969) and Happel and Jordan, (Chemical Process Economics, 2'nd ed., 1975) for preliminary estimation.

\section{Mass and Heat Flows}

The raw biomass material is assumed to be de-mineralized corn stover. A rate of 11,883 $\mathrm{lb} / \mathrm{hr}(5390 \mathrm{~kg} / \mathrm{hr})$ of corn stover to the pyrolyzer will therefore generate $(0.789+0.079) \times$ $5390=4680 \mathrm{~kg} / \mathrm{hr}$ of volatiles $(\mathrm{V})$. The total volatile pyrolyzer effluent (VE) comprise pyrolysis gas (G) at $426 \mathrm{~kg} / \mathrm{hr}$, water (W) at $562 \mathrm{~kg} / \mathrm{hr}$, organics (O) at $3692 \mathrm{~kg} / \mathrm{hr}$, as well as the fluidizing gas (FG) at about $5000 \mathrm{~kg} / \mathrm{hr}$.

$$
\mathrm{VE}=\mathrm{W}+\mathrm{G}+\mathrm{O}+\mathrm{FG}
$$

The combined water and organics, exclusive of levoglucosan (LG) are arbitrarily assumed to be divided equally between $\mathrm{L}$ and H. I.e., we write for the a light fraction $(\mathrm{L})$, a heavy fraction $(\mathrm{H})$.

$$
\begin{gathered}
\mathrm{L}=1756 \mathrm{~kg} / \mathrm{hr} \\
\mathrm{H}=1756 \mathrm{~kg} / \mathrm{hr} \\
\mathrm{LG}=742 \mathrm{~kg} / \mathrm{hr} .,
\end{gathered}
$$

After separation of LG, the residual part of the biooil is $\mathrm{H}+\mathrm{L}$.

Levoglucosan production rate is $742 \mathrm{~kg} / \mathrm{hr}$ assuming $100 \%$ recovery efficiency. Since hydrolysis to free sugars involves the addition of a water molecule to each LG molecule, this would correspond to a production rate of $824 \mathrm{~kg} / \mathrm{hr}$ of free sugars. 
A reflux stream R composed of light ends controls the upper temperature of the fractionator temperature while a quench stream Q composed of the components in the stored biooil controls the lower temperatures. The stored biooil is comprised of the primary oil less the anhydrosugars. Its composition is thus $49 \% \mathrm{~L}$ and $51 \% \mathrm{H}$.

However, using a heat capacity for biooil of $\sim 3.2 \mathrm{~kJ} / \mathrm{kg}-\mathrm{K}$ and $\sim 1 \mathrm{~kJ} / \mathrm{kg}-\mathrm{K}$ for FG, then considering only the sensible heat, we find that $2320 \mathrm{MJ} / \mathrm{hr}$ (i.e. from L+FG) would be available at $\sim 250{ }^{\circ} \mathrm{C}$ at a reference temperature of $20^{\circ} \mathrm{C}$.

These may be compared with the net heat required for pyrolysis which is, very roughly, just the sensible heat required to raise the biomass feed to the pyrolysis temperature, namely about $5000 \mathrm{MJ} / \mathrm{hr}$ at $\sim 480{ }^{\circ} \mathrm{C}$. Thus roughly half of the input heat could be recovered usefully under the conditions stated in the previous paragraph.

\section{Unit Operations}

\section{Fractionating Column}

LG must be separated from $\mathrm{H}$ in the lower end of the fractionator and from $\mathrm{L}$ in the upper end. In order to estimate the number of plates required for the lower end separation, we consider LG as the light key (LK) and consider Syringaldehyde $\left(\mathrm{BP} \sim 305^{\circ} \mathrm{C}\right)$ as the heavy key (HK).

Using the vapour pressure of levoglucosan as the correlation given by Suuberg,

$$
\ln \mathrm{P}[\mathrm{torr}]=32.391-14452 / \mathrm{T}[\mathrm{K}]
$$

the relative volatility is $\alpha_{\mathrm{LK} / \mathrm{HK}}=1616 / 760=2.13$. The Fenske equation gives an estimate or the number of trays at total reflux as

$$
N_{m}=\ln \left[\frac{\xi_{L K}\left(1-\xi_{H K}\right)}{\xi_{H K}\left(1-\xi_{L K}\right)}\right] / \ln \alpha_{L K / H K}
$$

where $\xi_{i}$ is the mass fraction of component $i$ in the overhead product. We assume a target of $\xi_{\mathrm{LK}}=0.98$ and of $\xi_{\mathrm{HK}}=0.20$, thus $N_{\mathrm{m}}=7$.

In the upper section $\mathrm{LG}$ is separated from $\mathrm{L}$. In this case $\mathrm{LG}$ is the heavy key and we take IsoEugenol $\left(\mathrm{BP} \sim 270{ }^{\circ} \mathrm{C}\right)$ as the light key. Thus $\alpha_{\mathrm{LK} / \mathrm{HK}}=760 / 322=2.36$. Taking targets of $\xi_{\mathrm{LK}}=0.80$ and of $\xi_{\mathrm{HK}}=0.02$, then $N_{\mathrm{m}}=6.2$.

Assuming $0.6 \mathrm{~m}$ height per tray and a tray efficiency of $80 \%$ gives an overall height of $13 * 0.6=9.8 \mathrm{~m}$ for the tray section. We include and additional $2 \mathrm{~m}$ disengagement space at the top for an overall column height of $\mathbf{1 2} \mathbf{~ m}$. 
Since there is a large overburden of non-condensable gas, we size the diameter on the basis that the total gas + vapour flow rate should be in the generally preferred range around $1 \mathrm{~m} / \mathrm{s}$. Assume that the entrance temperature is $400{ }^{\circ} \mathrm{C}$ and that the vapour density at this temperature is $1.18 \mathrm{~kg} / \mathrm{m}^{3}$, then the volumetric rate at the inlet is $(5000+4340) /(3600 \times 1.18)=2.20 \mathrm{~m}^{3} / \mathrm{s}$, giving a column diameter of $\mathbf{1 . 7} \mathbf{~ m}$. (A more accurate analysis should take account of the flooding limits of the trays.)

We estimate the reflux ratio, $r$, for the upper section of the column using the following correlation:

$$
r \approx r_{L K}=1.38 /\left[\left(\alpha_{L K / H K}-1\right)^{0.9}\left(1-\xi_{L K}\right)^{0.1}\right] .
$$

This gives $\boldsymbol{r} \sim \mathbf{1 . 6}$ so the total reflux flow is $\mathbf{R}=\mathbf{2 5 3 9} \mathbf{~ k g} / \mathbf{h r}($ Specific Gravity $=1.1)$.

The flow $\mathrm{Q}$ is estimated from that required to reduce the temperature of the incoming vapour from $400{ }^{\circ} \mathrm{C}$ to say $350{ }^{\circ} \mathrm{C}$. We find $\mathbf{Q} \sim \mathbf{5 0 3} \mathbf{~ k g} / \mathbf{h r}$. (Specific Gravity $=1.2$

\section{Heat Exchanger (Condenser)}

It is assumed that the condensing heat exchanger on the exit stream can be a basic shell and tube type since removal of the bottoms containing the heavy tars (pyrolytic lignin) removes the fouling problems they normally cause.

There is some question as to whether the condenser should be air or water-cooled. We shall assume that an air heat exchanger is used. It could provide hot air for biomass drying for instance. Another design issue is the desirable level of heat recovery, i.e. the final air temperature. We assume $150^{\circ} \mathrm{C}$.

We assume that the heat of vapourization of the volatile organics is roughly the same as that of levoglucosan as reported by Oja and Suuberg (J. Chem. Eng. Data, (1999) 44, 26$29)$, namely $\sim 0.62 \mathrm{MJ} / \mathrm{kg}$. Taking account of the water $\left(\Delta \mathrm{H}_{\mathrm{vap}} \approx 2.26 \mathrm{MJ} / \mathrm{kg}\right)$, we find an overall rough heat of vapourization of $\sim 1 \mathrm{MJ} / \mathrm{kg}$ for the condensable light end stream. (Note that this is very close to the estimated net heat for pyrolysis.)

Using the reflux ratio estimated above, the latent heat to be removed per second is $(2.6 \times 1587+0.49 \times 503) \times 1 / 3600=1.21 \mathrm{MW}$. The sensible heat to be removed per second at an exit temperature of say $50{ }^{\circ} \mathrm{C}$, which includes that of the gas as well as the vapour, is $(5395 \times 1+1587 \times 2.6 \times 3.2 \times(270-50) / 3600=1.14 \mathrm{MW}$. Thus the overall condenser duty is $\mathbf{Q}_{\mathbf{C}}=\mathbf{2 . 3 5} \mathbf{M W}$.

For finned 316 SS tubes, we assume the purchase cost in $1970 \$$ is.$\$ 144\left(\mathrm{~A} / \mathrm{ft}^{2}\right)^{0.75}$ while the installed cost is $\$ 324\left(\mathrm{~A} / \mathrm{ft}^{2}\right)^{0.750}$ and the overall heat transfer coefficient is $\mathrm{U}=90$ $\mathrm{BTU} /\left(\mathrm{hr} . \mathrm{ft}^{2}{ }^{\circ}{ }^{\circ}\right.$ ) based on bare non-finned tube surface. (Happel and Jordan, p. 226.) 


\section{Separator Drum}

On the basis of the total liquid flow, and assuming 5 mins. hold up time, the required volume is estimated at $0.66 \mathrm{~m}^{3}\left(23.3 \mathrm{ft}^{3}\right)$. Following standard ratios, the length is estimated at $8 \mathrm{ft}$ and the diameter as $2 \mathrm{ft}$. The material is SS clad carbon steel.

\section{Hydrolyser}

The hydrolyser is presumed to be a plain tubular reactor under laminar flow. Very little information is available on the kinetics of the hydrolysis of levoglucosan in high pressure water; neither is the optimum concentration known. We arbitrarily assume a first order rate constant of $20 \mathrm{~min}^{-1}$ and a concentration of $50 \%$ (equivalent to $55 \%$ free sugars in the product) so that only $\sim 688 \mathrm{~kg} / \mathrm{hr}$ of water for dilution would be required. (A small heat input may be required to adjust the temperature here. We neglect this.) Thus the total volume required is estimated to be $420 \mathrm{~L}$ (110 gal) so only about $10 \mathrm{ft}$ of 6 " tube would suffice. The associated pump would have negligible cost.

\section{Storage Tank (Sugar solution)}

Assume a carbon steel tank $(\mathrm{MPF}=2.1)$. A 20,000 gal tank would have more than three days production storage capacity.

\section{Pumps}

Pumps are required for both the efflux flow $\mathrm{R}$ and the quenching flow $\mathrm{Q}$, which are $\sim 2$ and $\sim 10 \mathrm{gal} / \mathrm{min}$, respectively.

\section{Summary}

The overall installed cost is $\$ 545,480$ in $2002 \$$ as detailed in the table below. 


\begin{tabular}{|l|c|c|c|c|c|c|}
\hline Equipment & $\begin{array}{c}\text { BC } \\
\mathbf{( \$ 1 9 6 8 )}\end{array}$ & MPF & MF & $\begin{array}{c}\text { UF } \\
\mathbf{2 0 0 2}\end{array}$ & $\begin{array}{c}\text { Uninstalled Cost } \\
\mathbf{( \$ 2 0 0 2})\end{array}$ & $\begin{array}{c}\text { Installed Cost } \\
\mathbf{( \$ 2 0 0 2})\end{array}$ \\
\hline $\begin{array}{l}\text { Empty Column } \\
\text { (316 SS clad) }\end{array}$ & 10,350 & 2.25 & 4.23 & 3.39 & 78,975 & 192,270 \\
\hline $\begin{array}{l}\text { Trays: sieve, 2 ft. } \\
\text { spacing (SS) }\end{array}$ & 3,274 & 1.7 & 1 & 3.39 & 18,866 & 18,870 \\
\hline $\begin{array}{l}\text { Separator Drum } \\
\text { (316 SS clad) }\end{array}$ & 1,145 & 2.25 & 4.23 & 3.39 & 8,736 & 36,950 \\
\hline $\begin{array}{l}\text { Heat exchanger } \\
\text { (SS tubes/CS shell) }\end{array}$ & 23,520 & 1 & - & 3.39 & 79,750 & 179,430 \\
\hline $\begin{array}{l}\text { Hydrolyser, } \\
\text { horizontal mount } \\
\text { (CS, 276 psi) }\end{array}$ & 330 & 1.35 & 3.18 & 3.39 & 1,100 & 3,950 \\
\hline $\begin{array}{l}\text { Sugar Soln. Tank } \\
\text { (CS; 20,000 gal) }\end{array}$ & 7,540 & 1 & - & 3.39 & 25,560 & 102,280 \\
\hline $\begin{array}{l}\text { 2 Liquid Pumps } \\
\text { (cast iron) }\end{array}$ & 1,020 & 1 & 3.38 & 3.39 & 3,460 & 11,730 \\
\hline & & & & & & \\
\hline Total & & & & & $\mathbf{\$ 5 4 5 , 4 8 0}$ \\
\hline
\end{tabular}

$\mathrm{BC}=$ Base cost

$\mathrm{MPF}=$ Material \& pressure factor

$\mathrm{MF}=$ Module factor

$\mathrm{UF}=$ Update factor

Installed Cost $=$ UF.BC(MPF + MF-1)

Uninstalled Cost $=$ UF. BC.MPF 


\section{Appendix B. Example Pro Forma Model}

- Oat Hulls

- Value-added Chemicals Option

- Renewable Energy Credit $=\$ 18 / \mathrm{MWh}$ 


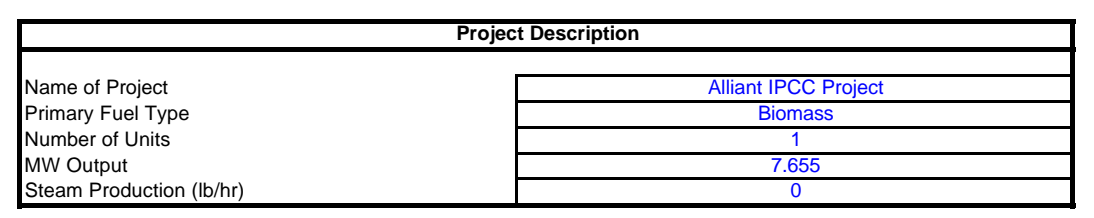

\begin{tabular}{|c|c|c|c|c|}
\hline \multicolumn{5}{|c|}{ Pro Forma Summary } \\
\hline \multirow{3}{*}{$\begin{array}{l}\text { Avg Debt Service Coverage Ratios } \\
\text { Min Debt Service Coverage Ratios }\end{array}$} & Total & Senior & Subordinate & \multirow[b]{4}{*}{ Investor 3} \\
\hline & 3.048 & 3.048 & $\# N / A$ & \\
\hline & 2.304 & 2.304 & 0.000 & \\
\hline \multirow{6}{*}{$\begin{array}{l}\text { NPV of A-T Cash Flows During Operation (\$1000) } \\
\text { + NPV of Year O A-T Cash Flows }(\$ 1000) \\
\text { - FV of Equity Contributions }(\$ 1000) \\
=\text { Project NPV (\$1000) } \\
\text { Internal Rate of Return }(\%) \\
\text { NPV Discount Rate }(\%)\end{array}$} & Project & Investor 1 & Investor 2 & \\
\hline & 11,655 & 11,655 & 0 & 0 \\
\hline & 0 & 0 & 0 & 0 \\
\hline & 11,655 & 11,655 & 0 & 0 \\
\hline & (0) & $(0)$ & 0 & 0 \\
\hline & $11.67 \%$ & & & \\
\hline
\end{tabular}

\begin{tabular}{|l|c|c|}
\hline \multicolumn{3}{|c|}{ Project Schedule } \\
\hline \multirow{3}{*}{\begin{tabular}{l|l|} 
Start of Construction \\
Construction Period (months)
\end{tabular}} & $\mathrm{COD} 1$ & $\mathrm{COD} 2$ \\
\cline { 2 - 3 } Start of Commercial Operation & Jan-2003 & $\# \mathrm{~N} / \mathrm{A}$ \\
\cline { 2 - 3 } End of Commercial Operation & 24 & $\# \mathrm{~N} / \mathrm{A}$ \\
\cline { 2 - 4 } & $\mathrm{Jan}-2005$ & $\# \mathrm{~N} / \mathrm{A}$ \\
\cline { 2 - 3 } & $\mathrm{Dec}-2032$ & $\# \mathrm{~N} / \mathrm{A}$ \\
\hline
\end{tabular}

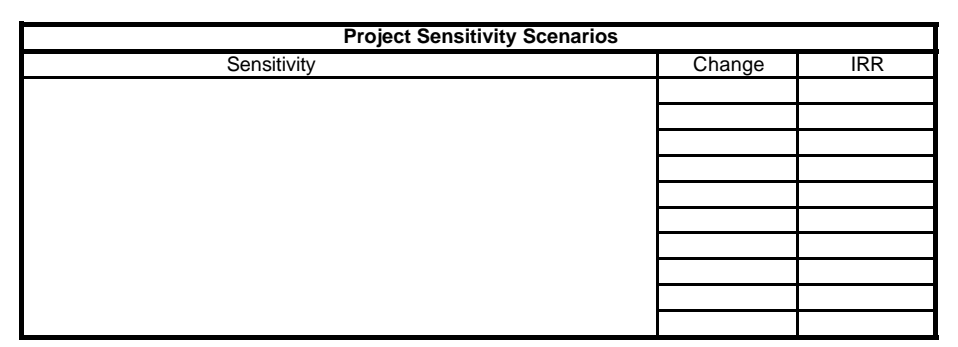

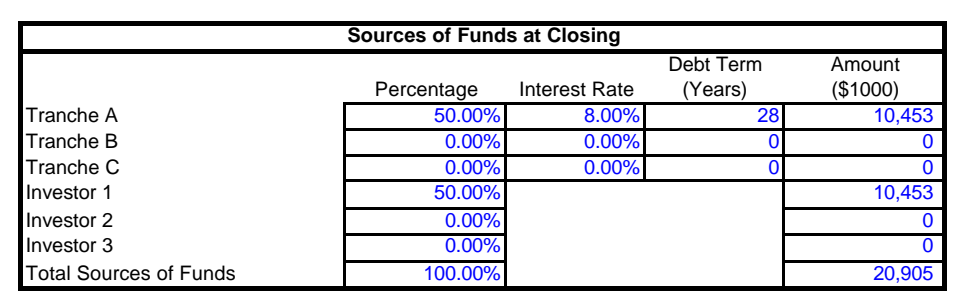

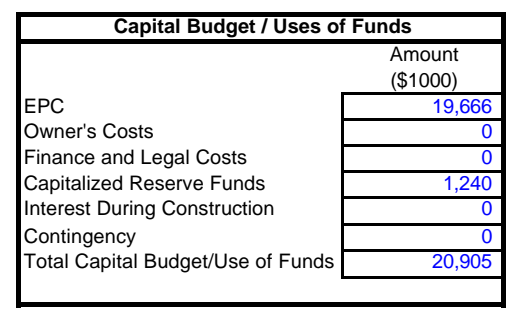




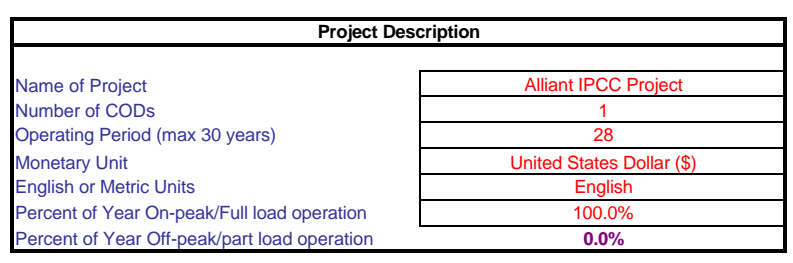

Cash Flow

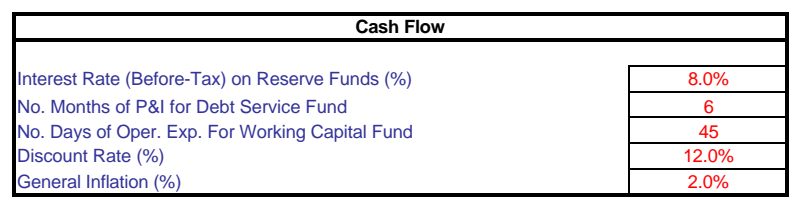

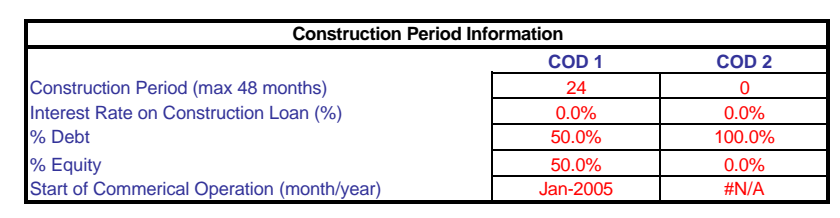

\begin{tabular}{|c|c|c|c|c|}
\hline \multicolumn{5}{|c|}{ Debt/Equity Information } \\
\hline & & COD 1 $(\$ 1000)$ & COD $2(\$ 1000)$ & Total $(\$ 1000)$ \\
\hline Percent Debt: & & & & \\
\hline (Senior) \% Tranche A & $50.0 \%$ & $\underline{10,453}$ & $\underline{0}$ & 10,453 \\
\hline (Senior) \% Tranche B & $0.0 \%$ & $\underline{0}$ & $\underline{0}$ & $\underline{0}$ \\
\hline (Subordinate) \% Tranche C & $0.0 \%$ & $\underline{0}$ & $\underline{0}$ & \\
\hline Total Long Term Debt & $\underline{50.0 \%}$ & 10,453 & $\underline{0}$ & 10,453 \\
\hline \% Investor 1 & $50.0 \%$ & 10,453 & 0 & 10,453 \\
\hline$\%$ Investor 2 & $0.0 \%$ & 0 & 0 & \\
\hline \% Investor 3 & $0.0 \%$ & $\underline{0}$ & $\underline{0}$ & $\underline{\underline{0}}$ \\
\hline Total Equity Contribution & $50.0 \%$ & $\underline{10,453}$ & $\underline{0}$ & 10,453 \\
\hline Total Sources of Funds & $100.0 \%$ & 20,905 & $\underline{\underline{0}}+>\rightarrow>$ & 20,905 \\
\hline
\end{tabular}

\begin{tabular}{|c|c|c|c|c|c|}
\hline \multicolumn{6}{|c|}{ Project Use of Funds } \\
\hline & & Depr. \% & COD 1 $(\$ 1000)$ & $\operatorname{COD} 2(\$ 1000)$ & Total $(\$ 1000)$ \\
\hline EPC Cost & & $100 \%$ & 19,666 & 0 & 19,666 \\
\hline \multicolumn{6}{|l|}{ Owner's Costs: } \\
\hline Site Purchase & & $0 \%$ & 0 & 0 & \\
\hline Infrastructure & & $100 \%$ & 0 & 0 & \\
\hline Start Up & & $100 \%$ & 0 & 0 & \\
\hline Spare Parts & & $100 \%$ & 0 & 0 & \\
\hline Construction Management Expenses & & $100 \%$ & 0 & 0 & $\underline{0}$ \\
\hline Construction Management Fees & & $100 \%$ & 0 & 0 & $\underline{0}$ \\
\hline Consultants & & $100 \%$ & 0 & 0 & \\
\hline Subtotal Owner's Costs & & $100 \%$ & 0 & 0 & $\underline{0}$ \\
\hline \multicolumn{6}{|l|}{ Financing Fees: } \\
\hline Up Front (\%) & $0.00 \%$ & $100 \%$ & $\underline{0}$ & $\underline{0}$ & $\underline{0}$ \\
\hline Commitment (\%) & $0.00 \%$ & $100 \%$ & $\underline{0}$ & $\underline{0}$ & $\underline{0}$ \\
\hline Subtotal Financing Fees & & $0 \%$ & 0 & 0 & $\underline{0}$ \\
\hline Legal Fees & & $100 \%$ & 0 & 0 & $\underline{0}$ \\
\hline \multirow{2}{*}{\multicolumn{6}{|c|}{ Initial Contribution to Funds: }} \\
\hline & & & & & \\
\hline Debt Service & & $0 \%$ & 473 & 0 & 473 \\
\hline Working Capital & & $0 \%$ & 767 & 0 & $\underline{767}$ \\
\hline Major Maintenance & & $0 \%$ & 0 & 0 & $\underline{0}$ \\
\hline Subtotal Initial Contributions to Funds & & 0 & 1,240 & $\underline{0}$ & 1,240 \\
\hline Interest During Construction & & $100 \%$ & $\underline{0}$ & $\underline{0}$ & $\underline{0}$ \\
\hline Total Capital Cost & & & $\underline{20,905}$ & $\underline{0}$ & $\underline{20,905}$ \\
\hline Total Depreciable Amount & & & 19,666 & $\underline{0}$ & 19,666 \\
\hline
\end{tabular}

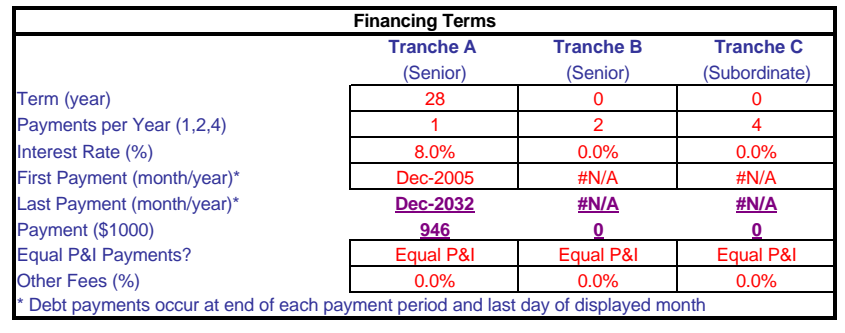

\begin{tabular}{|l|l|}
\hline \multicolumn{2}{|c|}{ Depreciation \& Tax Parameters } \\
\hline & \\
\hline \multicolumn{2}{|c|}{ Taxes (\%): } \\
Federal & \\
State & $0.0 \%$ \\
\hline Local & $0.0 \%$ \\
\hline Effective (Overridden) & $0.0 \%$ \\
Depreciation Method: & $30.0 \%$ \\
Double Declining Balance (DDB) & \\
Depreciation Asset Life (Years) & \\
Depreciation Convention & \\
Normal & \\
Tax Loss Treatment: & \\
Carryforward & \\
\hline
\end{tabular}




\begin{tabular}{|c|c|c|c|}
\hline \multicolumn{4}{|c|}{ Electric/Cogeneration $(\mathrm{E} / \mathrm{C})$ Performance } \\
\hline \multicolumn{2}{|l|}{ Electrical Outout. } & COD 1/Plant & $\operatorname{COD} 1+2$ \\
\hline $\begin{array}{l}\text { Electrical Output: } \\
\text { Customer } 1 \text { (MW) }\end{array}$ & & 77 & 80 \\
\hline Customer 2 (MW) & & $\frac{1.1}{0.0}$ & 0.0 \\
\hline Customer $3(\mathrm{MW})$ & & 0.0 & 0.0 \\
\hline Annual Capacity Factor (\%) & & $64.0 \%$ & $80.0 \%$ \\
\hline Degradation (\%) & & $1.0 \%$ & $0.0 \%$ \\
\hline Fuel 1: & Biomass & & \\
\hline Heat Rate, on-peak (Btu/kWh) & Input & 12,000 & \#DIV/O! \\
\hline Heat Input Rate, on-peak (MBtu/hr) & Calculate & 0.0 & 0.0 \\
\hline Heat Rate, off-peak (Btu/kWh) & Input & 12,000 & 10,000 \\
\hline Heat Input Rate, off-peak (MBtu/hr) & Calculate & 91.9 & 0.0 \\
\hline Heat Rate Degradation $(\%)$ & & $1.0 \%$ & $3.0 \%$ \\
\hline Percentage of Operation (\%) & & $100.0 \%$ & $80.0 \%$ \\
\hline Fuel 2: & Natural Gas & & \\
\hline Heat Rate, on-peak (Btu/kWh) & Input & 0 & 10,000 \\
\hline Heat Input Rate, on-peak (MBtu/hr) & Calculate & 0.0 & 0.0 \\
\hline Heat Rate, off-peak (Btu/kWh) & & 0 & 10,000 \\
\hline Heat Input Rate, off-peak (MBtu/hr) & Calculate & 0.0 & 0.0 \\
\hline Heat Rate Degradation $(\%)$ & & $0.0 \%$ & $3.0 \%$ \\
\hline Percentage of Operation (\%) & & $0.0 \%$ & $\underline{20.0 \%}$ \\
\hline
\end{tabular}

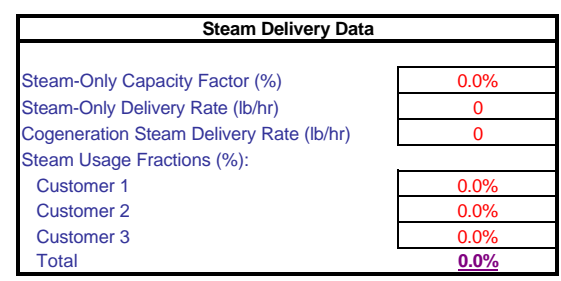

\begin{tabular}{|c|c|c|}
\hline \multicolumn{3}{|c|}{ Steam-Only Fuel Performance } \\
\hline \multirow{2}{*}{\multicolumn{2}{|c|}{ Fuel Type }} & All Units \\
\hline & & None \\
\hline Heat Rate (Btu/kWh) & & 0 \\
\hline Heat Input Rate (MBtu/hr) & Calculate & 0.0 \\
\hline Heat Rate Degradation (9) & & $0.0 \%$ \\
\hline
\end{tabular}

\begin{tabular}{|c|c|c|c|}
\hline & Revenues & & \\
\hline \multicolumn{3}{|l|}{ On-Peak Electric Rates: } & Escalation \\
\hline Customer 1 & $\$ / M W h$ & 35.000 & $2.0 \%$ \\
\hline Customer 2 & $\$ / M W h$ & 0.000 & $2.0 \%$ \\
\hline & $\$ / M W h$ & 0.000 & $2.0 \%$ \\
\hline \multicolumn{4}{|l|}{ Off-Peak Electric Rates: } \\
\hline Customer 1 & $\$ / M W h$ & 35.000 & $2.0 \%$ \\
\hline Customer 2 & $\$ / M W h$ & 0.000 & $2.0 \%$ \\
\hline Customer 3 & $\$ / M W h$ & 0.000 & $2.0 \%$ \\
\hline Ancillary Services & $\$ 1000$ & 0.000 & $2.0 \%$ \\
\hline \multicolumn{4}{|l|}{ Capacity Rates: } \\
\hline Capacity Uplift & $\$ / k w-y r$ & 24.000 & $2.0 \%$ \\
\hline Customer 1 & $\$ / k w-y r$ & 0.000 & $2.0 \%$ \\
\hline Customer 2 & $\$ k w-y r$ & 0.000 & $2.0 \%$ \\
\hline \multirow{2}{*}{\multicolumn{4}{|c|}{ Steam Sales Rates: }} \\
\hline & & & \\
\hline Customer 1 & $\$ / k l b$ & 0.000 & $2.0 \%$ \\
\hline Customer 2 & $\$$ \$klb & 0.000 & $2.0 \%$ \\
\hline \multirow{2}{*}{\multicolumn{4}{|c|}{$\begin{array}{l}\text { Customer } 3 \\
\text { Other Revenues: }\end{array}$}} \\
\hline & & & \\
\hline Renewable Energy Credit & $\$ 1000$ & 771.994 & $2.0 \%$ \\
\hline Anhydrosugar Sales & $\$ 1000$ & 5800.000 & $2.0 \%$ \\
\hline Char Sales & $\$ 1000$ & 154.165 & $2.0 \%$ \\
\hline Item 4 & $\$ 1000$ & 0.000 & $2.0 \%$ \\
\hline
\end{tabular}

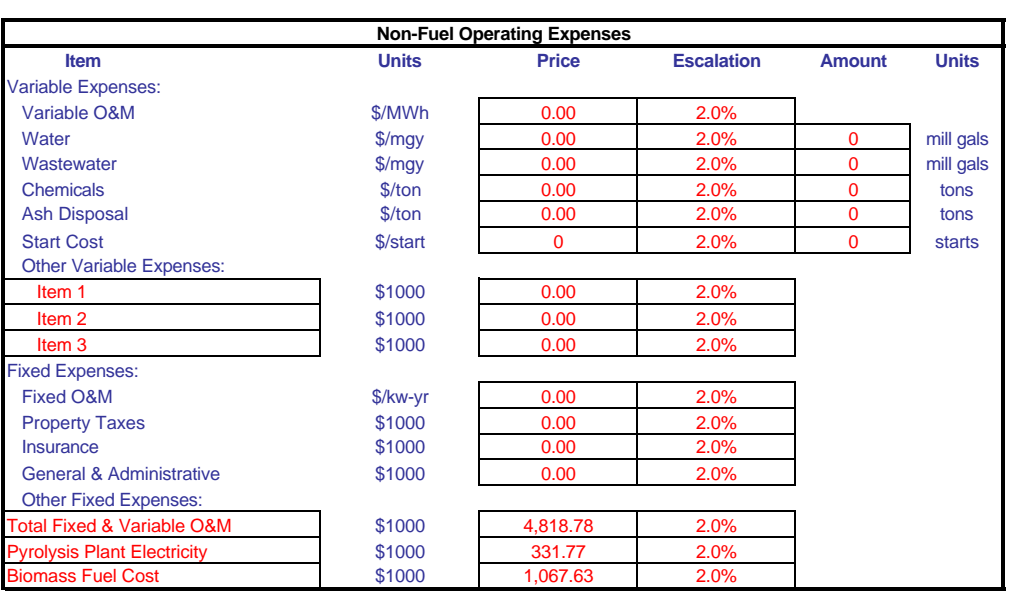

\begin{tabular}{|ll|c|c|}
\hline \multicolumn{4}{|c|}{ Fuel Operating Expenses } \\
\hline & Units & Price & Escalation \\
\cline { 3 - 4 } Elec/Cogen Fuel 1 & $\$$ MBtu & 0.000 & $2.0 \%$ \\
\cline { 3 - 4 } Elec/Cogen Fuel 2 & $\$ / M B$ Btu & 0.000 & $2.0 \%$ \\
\cline { 3 - 4 } Steam Fuel & \$/MBtu & 0.000 & $2.0 \%$ \\
\hline
\end{tabular}




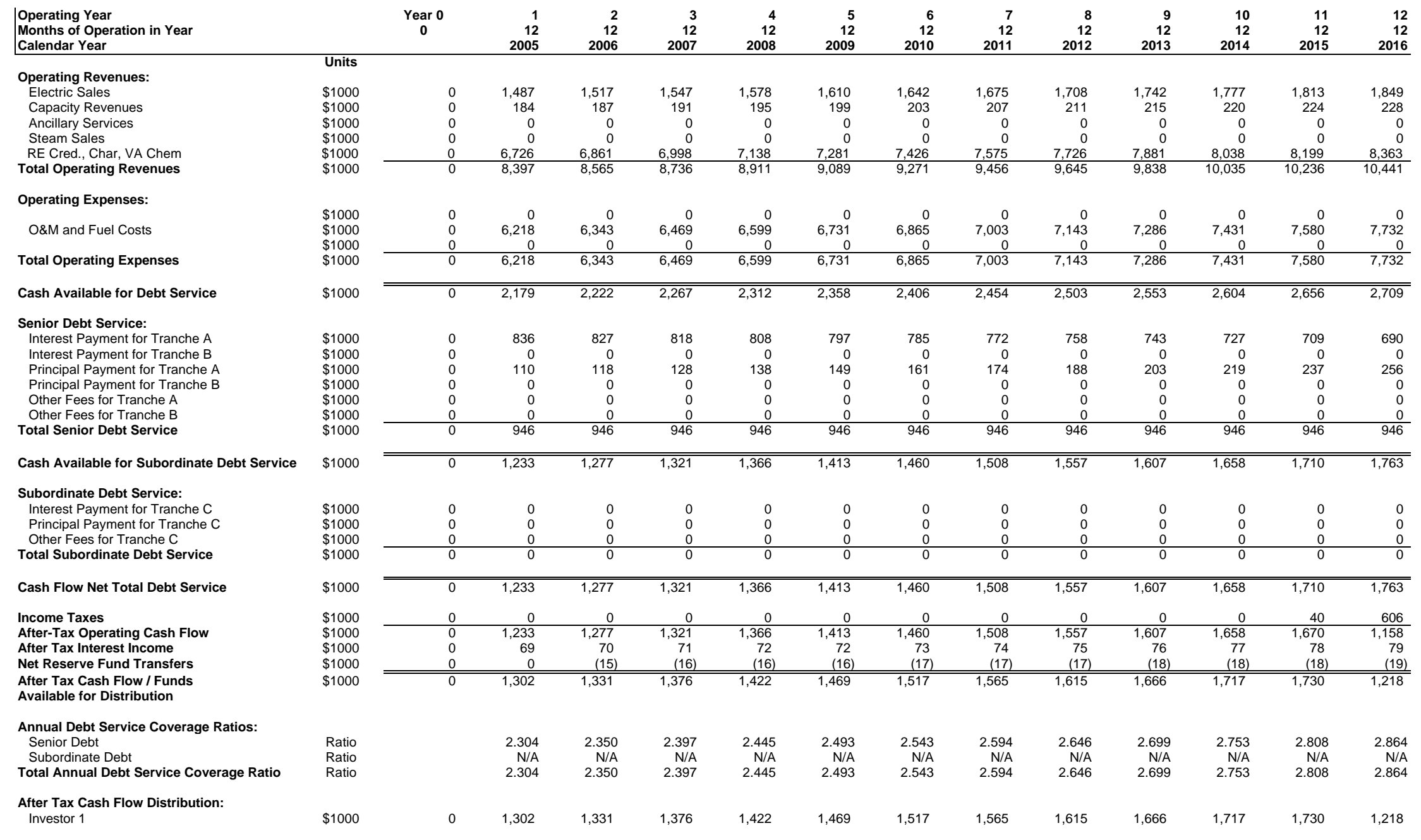




\begin{tabular}{|c|c|c|c|c|c|c|c|c|c|c|c|c|c|c|c|}
\hline $\begin{array}{r}13 \\
12 \\
2017 \\
\end{array}$ & $\begin{array}{r}14 \\
12 \\
2018 \\
\end{array}$ & $\begin{array}{r}15 \\
12 \\
2019 \\
\end{array}$ & $\begin{array}{r}16 \\
12 \\
2020 \\
\end{array}$ & $\begin{array}{r}17 \\
12 \\
2021 \\
\end{array}$ & $\begin{array}{r}18 \\
12 \\
2022 \\
\end{array}$ & $\begin{array}{r}19 \\
12 \\
2023 \\
\end{array}$ & $\begin{array}{r}20 \\
12 \\
2024 \\
\end{array}$ & $\begin{array}{r}21 \\
12 \\
2025 \\
\end{array}$ & $\begin{array}{r}22 \\
12 \\
2026 \\
\end{array}$ & $\begin{array}{r}23 \\
12 \\
2027 \\
\end{array}$ & $\begin{array}{r}24 \\
12 \\
2028 \\
\end{array}$ & $\begin{array}{r}25 \\
12 \\
2029 \\
\end{array}$ & $\begin{array}{r}26 \\
12 \\
2030 \\
\end{array}$ & $\begin{array}{r}27 \\
12 \\
2031 \\
\end{array}$ & $\begin{array}{r}28 \\
12 \\
2032 \\
\end{array}$ \\
\hline 1,886 & 1,924 & 1,962 & 2,001 & 2,041 & 2,082 & 2,124 & 2,166 & 2,210 & 2,254 & 2,299 & 2,345 & 2,392 & 2,440 & 2,488 & 2,538 \\
\hline 233 & 238 & 242 & 247 & 252 & 257 & 262 & 268 & 273 & 278 & 284 & 290 & 296 & 301 & 307 & 314 \\
\hline & 0 & 0 & 0 & 0 & 0 & 0 & 0 & 0 & 0 & 0 & 0 & 0 & 0 & 0 & 0 \\
\hline & & 0 & 0 & 0 & 0 & 0 & 0 & 0 & 0 & 0 & 0 & 0 & 0 & 0 & 0 \\
\hline 8,530 & 8,701 & 8,875 & 9,053 & 9,234 & 9,418 & 9,607 & 9,799 & 9,995 & 10,195 & 10,399 & 10,606 & 10,819 & 11,035 & 11,256 & 11,481 \\
\hline 10649 & 10,862 & 11,080 & & 11,527 & 11,758 & 11,993 & 12,233 & 12,477 & 12,727 & 12,982 & 0,000 & 13,506 & 13,7 & $\frac{11,2052}{14,050}$ & \\
\hline
\end{tabular}

\begin{tabular}{|c|c|c|c|c|c|c|c|c|c|c|c|c|c|c|c|}
\hline & 0 & 0 & & 0 & 0 & 0 & 0 & 0 & 0 & 0 & 0 & c & 0 & 0 & 0 \\
\hline 7,886 & 8,044 & 8,205 & 8,369 & 8,536 & 8,707 & 8,881 & 9,059 & 9,240 & 9,425 & 9,613 & 9,805 & 10,002 & 10,202 & 10,406 & 10,614 \\
\hline $\begin{array}{r}0 \\
7,886\end{array}$ & $\begin{array}{r}0 \\
8,044\end{array}$ & $\begin{array}{r}0 \\
8,205\end{array}$ & $\begin{array}{r}0 \\
8,369\end{array}$ & $\begin{array}{r}0 \\
8,536\end{array}$ & $\begin{array}{r}0 \\
8,707\end{array}$ & $\begin{array}{r}0 \\
8,881\end{array}$ & $\begin{array}{r}0 \\
9,059\end{array}$ & $\begin{array}{r}0 \\
9,240\end{array}$ & $\begin{array}{r}0 \\
9,425\end{array}$ & $\begin{array}{r}0 \\
9,613\end{array}$ & $\begin{array}{r}0 \\
9,805\end{array}$ & $\frac{d}{10,002}$ & $\begin{array}{r}0 \\
10,202\end{array}$ & $\frac{0}{10,406}$ & $\begin{array}{r}0 \\
10,614\end{array}$ \\
\hline 2,76 & 2,818 & 2,875 & 2,932 & 2,991 & 3,051 & 3,112 & 3,174 & 3,238 & 3,302 & 3,368 & 3,436 & 3,504 & 3,575 & 3,646 & \\
\hline
\end{tabular}

\begin{tabular}{|c|c|c|c|c|c|c|c|c|c|c|c|c|c|c|c|}
\hline 670 & 648 & 624 & 598 & 570 & 540 & 508 & 473 & 435 & 394 & 350 & 302 & 251 & 195 & 135 & 70 \\
\hline 0 & 0 & 0 & 0 & 0 & 0 & 0 & 0 & 0 & 0 & 0 & 0 & 0 & 0 & 0 & 0 \\
\hline 276 & 298 & 322 & 348 & 376 & 406 & 438 & 473 & 511 & 552 & 596 & 644 & 695 & 751 & 811 & 876 \\
\hline 0 & 0 & 0 & 0 & 0 & 0 & 0 & 0 & 0 & 0 & 0 & 0 & 0 & 0 & 0 & 0 \\
\hline 0 & 0 & 0 & 0 & 0 & 0 & 0 & 0 & 0 & 0 & 0 & 0 & 0 & 0 & 0 & 0 \\
\hline 0 & 0 & 0 & 0 & 0 & 0 & 0 & 0 & 0 & 0 & 0 & 0 & 0 & 0 & 0 & 0 \\
\hline 946 & 946 & 946 & 946 & 946 & 946 & 946 & 946 & 946 & 946 & 946 & 946 & 946 & 946 & 946 & 946 \\
\hline 1,817 & 1,873 & 1,929 & 1,987 & 2,045 & 2,105 & 2,166 & 2,228 & 2,292 & 2,356 & 2,423 & 2,490 & 2,559 & 2,629 & 2,700 & 2,773 \\
\hline
\end{tabular}

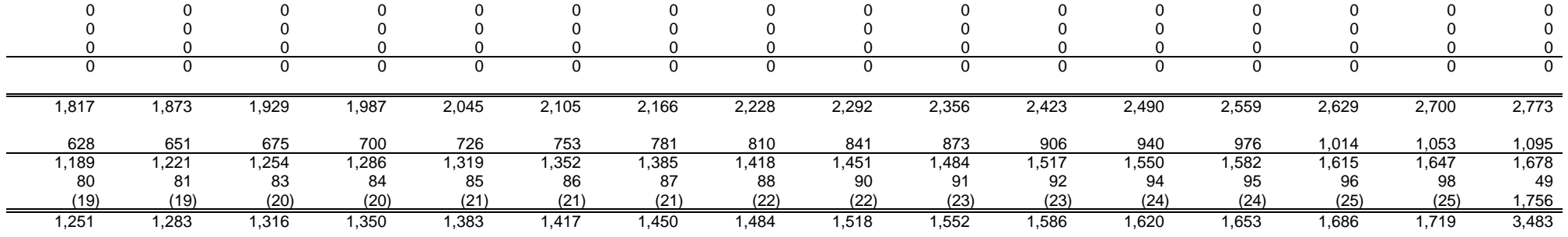

\begin{tabular}{|c|c|c|c|c|c|c|c|c|c|c|c|c|c|c|c|}
\hline 2.921 & 2.980 & 3.039 & 3.100 & 3.162 & 3.226 & 3.290 & 3.356 & 3.423 & 3.491 & 3.561 & 3.632 & 3.705 & 3.779 & 3.855 & $\begin{array}{r}3.932 \\
N / A\end{array}$ \\
\hline $\begin{array}{l}\mathrm{N} / \mathrm{A} \\
2921\end{array}$ & $\begin{array}{r}\mathrm{N} / \mathrm{A} \\
2980\end{array}$ & $\begin{array}{r}\mathrm{N} / \mathrm{A} \\
3039\end{array}$ & $\begin{array}{r}\mathrm{N} / \mathrm{A} \\
3100\end{array}$ & N/A & N/A & N/A & N/A & N/A & N/A & N/A & $\mathrm{N} / \mathrm{A}$ & N/A & $\begin{array}{r}\text { N/A } \\
3777\end{array}$ & N/A & $\begin{array}{r}\mathrm{N} / \mathrm{A} \\
3.932\end{array}$ \\
\hline 251 & 1283 & 1316 & 1350 & 1.383 & 1.417 & 1.450 & 1.484 & 1518 & 1552 & 1586 & 1620 & 1653 & 1686 & 1719 & 3.483 \\
\hline
\end{tabular}

